\title{
THE RELATIONSHIP BETWEEN ELECTRONIC NURSING CARE REMINDERS AND MISSED NURSING CARE
}

\author{
by \\ Ronald J. Piscotty \\ A dissertation submitted in partial fulfillment \\ of the requirements for the degree of \\ Doctor of Philosophy \\ (Nursing) \\ in The University of Michigan \\ 2013
}

Doctoral Committee:

Professor Beatrice Kalisch, Chair

Assistant Professor Jane Brokel, University of Iowa

Assistant Professor AkkeNeel Talsma

Assistant Professor Kai Zheng 


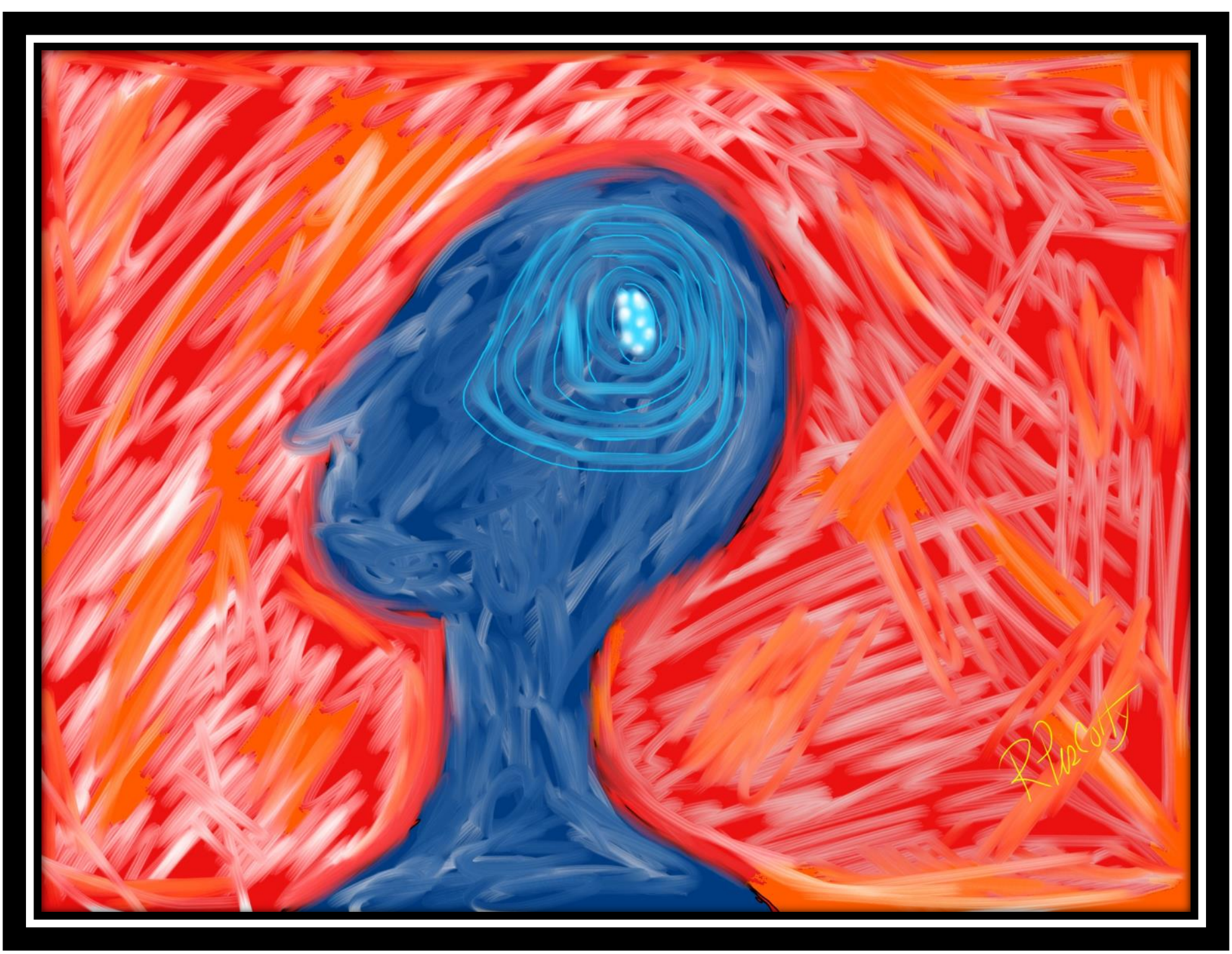


(C) Ronald Piscotty 2013 


\section{DEDICATION}

I dedicate this doctoral dissertation to Dr. Diane Norris, PhD, RN. As Associate Dean not only did you give me the me the opportunity to teach at Oakland University in 2007, but you also gave me hope. This was a very troubling time in my life and your kindness, generosity, guidance, support, and helped to ensure my present success as an educator, scholar, and as a person. I will be forever changed for knowing you and forever grateful that you came into my life. You were taken from us all too soon. You will be forever missed and never forgotten. 


\section{ACKNOWLEDGEMENTS}

I would like to specially thank Dr. Kalisch (Bea) for all that she has done to help me succeed as a future scholar and professor. It would not have been possible for me to complete the program without your support, guidance, mentoring, and wisdom. I will be forever grateful for having such an amazing person come into my life.

A very special thank you goes to my committee members Dr. Brokel, Dr. Talsma, and Dr. Zheng for all of their amazing support, feedback, and guidance throughout this process.

I would like to thank my mentor Dr. Huey-Ming Tzeng. Your guidance, support, and encouragement at the beginning of the doctoral program were integral to my success. I would not have been so successful in publishing manuscripts and presenting at conferences if it was not for your persistence. I exceeded the goal we agreed to when we first met to have at least three publications by the end of the doctoral program.

I also want to acknowledge my colleagues at Oakland University School of Nursing for being so supportive of my doctoral education. Your kind thoughts and words of encouragement helped me stay the course.

I would like to thank Joe D'Angelo for being supportive of my return to school and always encouraging me when I needed it most.

I would like to thank my friend, classmate, and colleague Lenette Jones. I remember the day we met at the Rackham Summer Institute, we were both so lost. I'm so glad we became friends. I would not have made it through the program without your constant support and listening ear. You are a true friend.

Finally, I would like to thank my father and mother (Ron Sr. and Phyllis) for always telling me I could do anything I set my mind to and also being supportive of any endeavor I decided to take on. 


\section{TABLE OF CONTENTS}

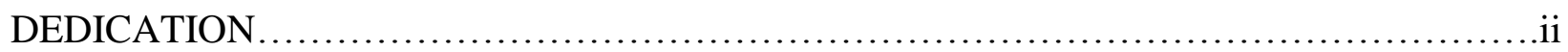

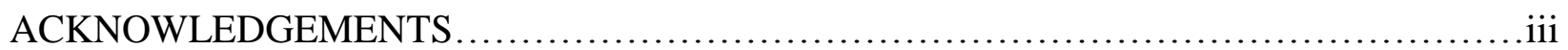

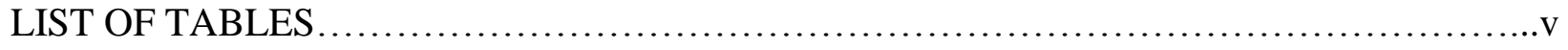

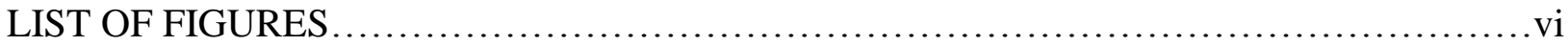

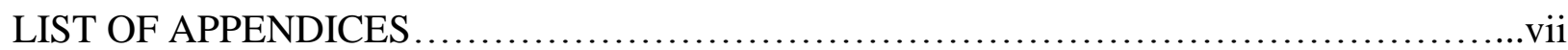

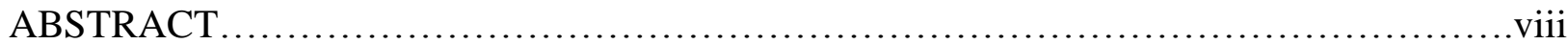

\section{CHAPTER}

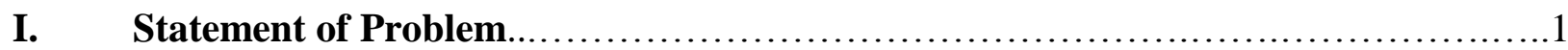

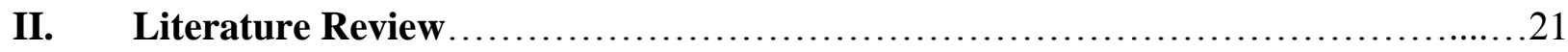

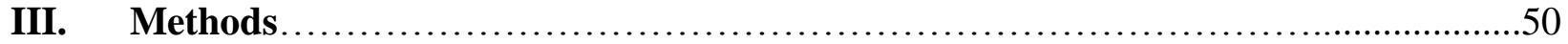

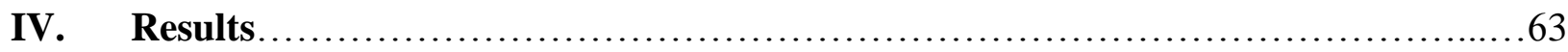

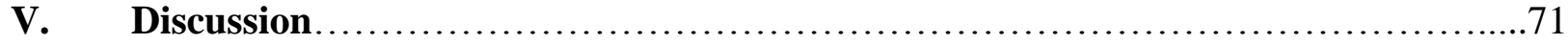

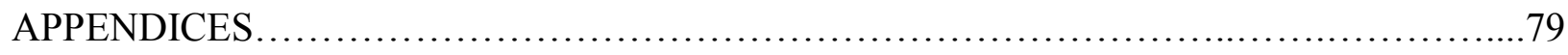

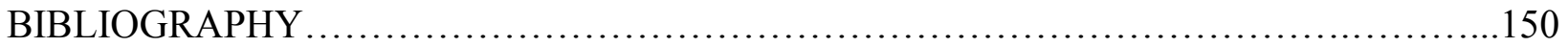




\section{LIST OF TABLES}

\section{TABLE}

1. Conceptual definitions and empirical indicators of dependent and independent variables......16

2. Conceptual definitions and empirical indicators of control variables......................17

3. Synthesis of key findings: CDSS literature review.................................. 32

4. Synthesis of key findings: Missed nursing care literature review $\ldots \ldots \ldots \ldots \ldots \ldots \ldots \ldots \ldots \ldots 47$

5. Nursing Care Reminders Survey: Pilot one descriptive statistics.........................54

6. Nursing Care Reminders Survey: Pilot two descriptive statistics.......................55

7. Demographic characteristics................................................... 64 


\section{LIST OF FIGURES}

\section{FIGURE}

1. Modified Structure Process Outcome Model.........................................15

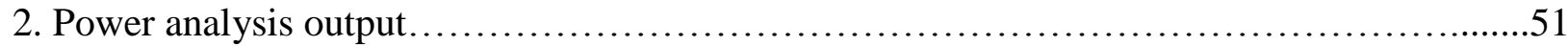

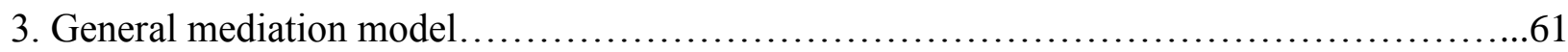

4. Test of the medication model with regression analysis.................................68 


\section{LIST OF APPENDICES}

\section{APPENDIX}

A. Clinical Decision Support System Literature Review Matrix...................................................80

B. Missed Nursing Care Literature Review Matrix.........................................107

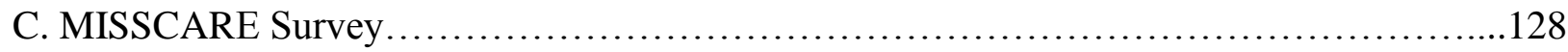

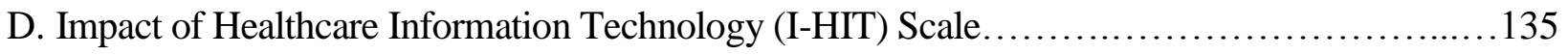

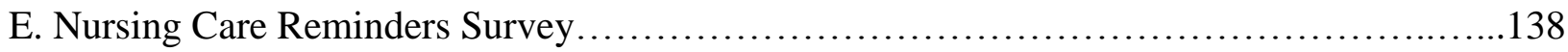

F. Standardized Form to Collect Unit RNHPPD and CMI..................................142

G: Standardized Email Sent to Registered Nurses ..................................... 144

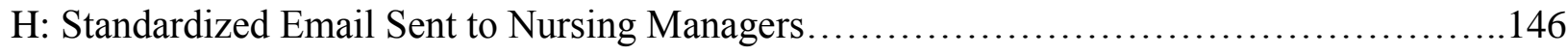

I: Standardized Flyer to Participate in Study ............................................... 148 


\begin{abstract}
Purpose: The purpose of this descriptive study was to: (1) determine the relationship between nurses' level of use of reminders and missed nursing care, (2) examine mediators that may exist among variables, and (3) compare nurses with positive/negative reports on the impact of health care information technology on practice and level of use, to determine if they have lower levels of missed nursing care.
\end{abstract}

Conceptual Framework: A modified Structure, Process, and Outcome Model of Healthcare Quality guided this study. In the modified model it was hypothesized that an electronic health record with nursing care reminders (structure) will directly impact registered nurse usage of nursing care reminders. The model suggests that the registered nurses' perceived impact of healthcare information technology on their practice will mediate the relationship between the levels of registered nurse use of the reminders and missed nursing care.

Subjects: The sample $(N=165)$ consisted of staff nurses employed at a local hospital in the Midwestern United States during Fall 2012. The majority of the respondents held a Bachelor's Degree as their highest level of education $(n=114,69.1 \%)$, with $67.1 \%(n=110)$ of those participants having a Bachelor's of Science degree in Nursing (BSN). The majority of respondents were female $(n=145,87.9 \%)$ and between the ages of 25 and $34(n=61,37.0 \%)$. Over half of the participants in the study $(n=104,63.0 \%)$ worked on a medical surgical unit. Methods: Hospital and university institutional review board approval was obtained. Surveys were administered online using the Qualtrics survey software. An email was sent to each nurse 
inviting him or her to participate. Unit managers were contacted via email to inform them of the study. A reminder was sent to each nurse twice per week during the study period. Flyers encouraging participation were placed by time clocks on each unit. All surveys were due within four weeks from the initiation of the study. Demographic data were analyzed using descriptive statistics and adjusted relationship, mediation, and comparisons were analyzed using hierarchical multiple regression analysis.

Results: There was a significant negative relationship (beta $=-.28, p<.001$ ) between nursing care reminder usage and missed nursing care. There was a significant negative relationship (beta $=-.34, p<.001)$ between the impact of healthcare information technology on practice and missed nursing care. Mediation was also determined to be occurring between nursing care reminders, impact of healthcare information technology on practice, and missed nursing care. Nurses with higher reports of reminder usage had decreased reports of missed nursing care (beta $=-.22, p<.004)$. Nurses with higher perceptions of impact of healthcare IT (I-HIT) had decreased reports of missed nursing care (beta $=-.27, p=.001)$.

Conclusions: The results of this study are significant and can be used to encourage nurses to use nursing care reminders, helpful for information system designers when designing nursing care reminders, and helpful to healthcare organizations in assessing the impact of technology on nursing practice. It is imperative that missed nursing care be decreased to improve patient and organizational outcomes. Nursing care reminders may be a viable solution to reduce missed nursing care in a technology rich healthcare environment. 


\section{Chapter I}

\section{Statement of Problem}

\section{Introduction}

Health care information technology (HIT) is being implemented at an ever-increasing rate in both acute care and ambulatory care settings in the United States. The impetus to implement these systems has come from seminal works, such as the Institute of Medicine's (IOM) To Err Is Human and Crossing the Quality Chasm (Institute of Medicine [IOM], 1999; 2001). These works recommended and laid the foundation for using information technology to improve patient safety and health care outcomes (IOM, 1999; 2001). The adoption of HIT is imperative for improving the health of the nation, and as such, it is one of the Healthy People 2020 proposed recommendations (U.S. Department of Health and Human Services, 2009). The IOM has also listed the implementation of HIT and clinical decision support systems (CDSSs) as one of its 100 priority areas of research (IOM, 2009).

HIT also received a significant amount ( $\$ 36$ billion) of funding under the American Recovery and Reinvestment Act (ARRA) of 2009 in order to support the rapid implementation and adoption of HIT in the country (Healthcare Information Management and Systems Society [HIMSS], 2010). The focus on HIT as a national strategy to contain health care costs and improve quality and safety of care is to be commended, but there has been very little research describing how HIT impacts nursing practice (Dykes, Huryley, Cashen, Bakken, \& Duffy, 2007). The cost-effectiveness and quality enhancing properties of (HIT) are oft cited as compelling reasons and catalysts for increased implementation, but the evidence base is inconclusive 
(Goldzweig, Towfigh, Maglione, \& Shekelle, 2009). This is of great importance as the largest group of health care providers in the nation is registered nurses.

The effects of hastily and poorly implemented HIT systems have been highlighted in the media and the literature (Ash, 2007; Han et al., 2005; Koppel et al., 2005). When systems are poorly implemented, the outcome can be "unintended consequences," which can increase error rates or result in errors that had not been seen before the implementation. These errors can severely affect the quality of care and patient safety. Causes of unintended consequences have been linked to a poor understanding of clinician workflow and systems that are ill prepared to support clinician workflow (Aarts, Ash, \& Berg, 2007; Harrison, Koppel, \& Bar-Lev, 2007).

In contrast, well-designed systems that incorporate CDSS and interdisciplinary communication may actually improve care (Dykes et al., 2007). This is accomplished by enabling nurses to more easily monitor, detect changes in patient conditions earlier, and improve communication within the healthcare team (Dykes et al., 2007). These systems provide alerts, reminders, and/or recommendations that are used to guide nursing practice. These prompts are often designed to deliver evidence-based suggestions to guide practice or influence clinical decision-making.

\section{CDSS: An Overview}

Hunt, Haynes, Hanna, and Smith (1998) defined CDSS as, “... any software designed to directly aid in clinical decision making in which characteristics of individual patients are matched to a computerized knowledge base for the purpose of generating patient-specific assessments or recommendations that are then presented to clinicians for consideration" (pp. 1339-1340). Kawamoto, Houlihan, Balas, and Lobach (2005) expanded this definition to include both electronic and non-electronic systems. Thus, a CDSS can include: paper-based systems, 
standalone systems such as diagnostic algorithms, application integrated systems such as those embedded in computerized provider order entry (CPOE) systems, systems ?integrated such as those found in electronic health records (EHR), and enterprise integrated systems that share and monitor data across systems and platforms (e.g., between clinical systems and financial systems). The type of CDSS that will be of interest in this study is one that is integrated into an electronic health record (EHR).

There are several functions of CDSSs: (1) alerts (e.g., allergic reaction warnings), (2) reminders (e.g., antibiotic order renewal), (3) clinical guideline recommendations, (4) diagnostic support, (5) surveillance (e.g., tracking H1N1), (6) disease prevention (e.g., yearly mammography), (7) disease management (e.g., monitoring A1C in type II diabetics), and (8) prescription or medication management (e.g., anticoagulant dosage titrations) (Hunt et al., 1998; Kowamoto et al., 2005). The focus of this study will be to examine nursing care reminders.

\section{Missed Nursing Care}

Furthermore, little is known regarding the actual process of nursing care and how that contributes to quality and safety. Nursing process is often termed a "black box" as it is yet to be widely studied and understood (Kalisch, McLaughlin, Waller, 2012). Missed nursing care is a measure of nursing process and is considered an error of omission (failing to do the right thing) versus an error of commission (doing the wrong thing) (Agency for Healthcare Research and Quality [AHRQ], 2011; Kalisch, Landstrom, \& Williams, 2009). Missed nursing care is defined as any aspect of required patient care that is omitted (either in part or whole) or delayed (Kalisch, Landstrom, \& Hinshaw, 2009). Similar concepts to missed nursing care include care rationing and unfinished care (Lawless, Wan, \& Zeng, 2010; Schubert et al., 2008; Sochalski, 2004). The AHRQ suggests that errors of omission are much more common than errors of commission and 
that they are often unreported (2011). Kalisch has conducted a significant amount of basic research regarding missed nursing care. This foundational work provides a body of knowledge regarding missed nursing care to guide more detailed research.

The logical next steps regarding missed nursing care research are to examine relationships between possible decision support interventions to reduce missed nursing care. In this regard, an application of HIT can be viewed as a potential intervention to decrease missed nursing care. It is hypothesized that nurses that have positive perceptions about the impact of HIT (I-HIT) on their work will report less missed nursing care. Nursing care reminders are of particular interest as they are considered a form of CDSS. Nursing care reminders are items that the nurse is expected to complete before the end of their shift. The care reminders are delivered to nurses in a variety methods such as "dashboard" alerts, worklists or queues, order lists, pop-up reminders, and/or reminders integrated into other modules of the EHR such as an intervention list in the care planning documentation, among others.

\section{Significance to Nursing}

This study is a first step in determining if there is a relationship between electronic nursing care reminders and missed nursing care. This is of great importance as it is hypothesized that an electronic system that has nursing reminders should result in decreased missed nursing care. In several studies, the primary reason for missed nursing care was related to nurse staffing adequacy, specifically labor resources (Gravlin \& Bitner, 2010; Kalisch, 2009; Kalisch et al., 2009; Lawless et al., 2010). When a deficit in the adequacy of nursing labor resources is present, this may lead to missed nursing care. When nurses are faced with a shortage of resources and increased patient loads potential interruptions and distractions may occur. 
One of the major negative effects of decreased labor resources on nursing practice centers on its potential to cause distractions and interruptions (Bittner, Gravlin, Hansten, \& Kalisch, 2011). Pape (2002) described a distraction as anything that diverts one's attention from achieving a desired goal. The primary impact of distraction is the filling of working memory due to information overload or competing attention (Pape et al., 2005). Pape et al. (2005) stated that working memory is where temporary information is stored, and since distractions can impact working memory, they may result in a loss of concentration, and thus, lead to missing care. In a recent case analysis, Brixey, Robinson, Johnson, Johnson, Turely, \& Zhang (2007) defined an interruption as any break in human performance by an internal or external stimulus.

Brixey et al. (2007) defined five attributes of an interruption as: (1) a human experience, (2) an intrusion of an unplanned secondary task, (3) discontinuity, (4) externally or internally initiated, and (5) situated within a context. Brixey et al. (2007) noted that interruptions in work settings such as aviation, nuclear power plants, and healthcare could result in catastrophic failures including loss of life. Interruptions and distractions can have an impact on nurses working memory. Unless the nurse is reminded in some way, a nursing intervention may be missed. Nursing care reminders are an intervention to remind nurses of missed nursing care during their shift (Kalisch \& Aebersold, 2010).

The second most common reason for missed care is material resources (Gravlin \& Bitner, 2010; Kalisch, 2009; Kalisch et al., 2009). Specifically, missing equipment/supplies, medications, and/or equipment not functioning (Kalisch et al., 2009). Electronic reminders may be useful in addressing a lack of material resources as a nurse may move on to another task while waiting for the missing equipment, supplies, or medications to arrive. The nurse may then experience an interruption and forget to administer the required intervention. The reminder may 
serve as a cue that the activity or intervention needs to be completed. This may thus result in a decreased amount of missed nursing care.

The third most common reason for missed nursing care is communication and teamwork (Gravlin \& Bitner, 2010; Kalisch, 2009; Kalisch et al., 2009). This includes such things a communication breakdowns, poor care handoffs, and others not providing required care as delegated, among others. Electronic reminders may improve communication and teamwork and as such decrease the amount of missed nursing care. This may occur when communications breakdown occur. The reminder may serve to notify the nurse that a particular activity or intervention has not been delivered. The nurse can then follow-up with the appropriate individual to ensure activity or intervention completion.

Additionally, our understanding of the impact of missed nursing care on patient care outcomes is not well understood. In one study, missed nursing care was found to be a mediating factor in increasing patient falls (Kalisch, Tschannen, \& Lee, 2012). In another study, care rationing was a significant predictor of six patient outcomes: (1) patient satisfaction, (2) medication errors, (3) patient falls, (4) nosocomial infections, (5) critical incidents, and (6) pressure ulcers (Schubert et al., 2008). If missed nursing care, a form of care omissions is indeed having a negative impact on patient outcomes, interventions need to be developed to reduce the amount of missed nursing care.

\section{Aim}

The aim of this study is to understand the impact of HIT (nursing care reminders) on nursing practice process (missed nursing care).

\section{Purpose}


The purpose of this study is to: (1) determine the relationship between nurses' level of use of reminders and missed nursing care, (2) examine mediators that may exist among variables, and (3) compare nurses with positive/negative reports of the impact of HIT on practice and level of use, to determine if they have lower levels of missed nursing care.

\section{Conceptual Framework}

\section{Conceptual Framework Analysis}

The overall research trajectory of the author of this study is to understand the impact of HIT on nursing practice. The plan is to eventually examine this from a structure to outcome perspective. It is the author's overall hypothesis that although structure or HIT can have a direct impact on process and outcomes, there are mediating and moderating variables that influence or explain a greater part of the variance. Additionally, HIT systems or even applications may have little direct improvement on process and outcomes. An understanding of the underlying relationships between HIT applications and the impact on process is desperately needed. Once the relationships are established, the examination of the associations between HIT and health and organizational outcomes can occur. The author's particular interest is in regard to nursing care reminders embedded within the EHR and their potential to decrease the amount of missed nursing care.

Theoretical foundations for both nursing health services research and nursing informatics research are not well established (Effken, 2003; Mitchell, Ferketich, \& Jennings, 1998). Many theories that are used are borrowed from other disciplines such as business management, computer science, information science, and public health. There is currently no widely accepted unifying theory of nursing health services research or nursing informatics research (Effken, 2003; Mitchell, Ferketich, \& Jennings, 1998). There have been attempts in both of these areas to 
develop such a unifying theory (Effken, 2003; Mitchell, Ferketich, \& Jennings, 1998). These attempts have been met with mixed success.

Four conceptual frameworks were examined for this study. The four frameworks examined are:

1. Structure, Process, and Outcome (SPO) Model of Healthcare Quality (Donabedian, 1966; $1969 ; 1988)$.

2. Quality Health Outcomes Model (QHOM) (Mitchell et al., 1998).

3. The Informatics Research Organizing (IRO) Model (Effken, 2003).

4. The Technology Acceptance Model (TAM) (Davis, 1989; Davis, Bagozzi, \& Warshaw; 1989).

Each of these frameworks will be examined for major concepts, commonalities and differences among the models, and critiqued in subsequent sections.

\section{Structure, Process, and Outcome Model of Healthcare Quality}

Donabedian proposed the Structure, Process, and Outcome Model of Healthcare Quality in 1966. The model posits that health care structure, process, and outcomes and associated contextual factors are the underpinnings of healthcare quality. Donabedian (1969) described structure as organizational components or factors such as actual workspace, organizational culture, resource allotment, and clinician characteristics among others. Process is described as the act of care. This would include making clinical decisions and then implementing interventions based on the plan of care. Outcomes were described as the end result of care (Donabedian, 1969). Donabedian (1988) recommended that health research studies should include variables from all three areas (structure, process, and outcome) because there are many factors that influence the quality of care and a weakness in one may be supplemented by strength 
in another. Mitchell et al. (1998) state that the SPO is traditionally viewed as a linear model with no feedback loops. Although, some may view the SPO in this manner, it can be inferred that Donabedian did not intend that the model was linear in nature, nor that is was not dynamic in that it did not include feedback loops. Donabedian's statement above that all three components of the SPO be examined in any research study supports this inference.

\section{Quality Health Outcomes Model (QHOM)}

The Quality Health Outcomes Model (QHOM) was derived from Donabedian's SPO model. The model contains four main concepts: (1) system, (2) client, (3) interventions, and (4) outcomes (Mitchell et al., 1998). In the QHOM system is defined in a similar nature as structure in the SPO model in that Mitchell et al. (1989) includes individual, organizational, and group characteristics of the system. The client concept is defined as individual, family, or community characteristics. Interventions are clinical processes that are either derived directly or indirectly (Mitchell et al., 1989). Outcomes are defined as the end results of both treatment interventions and/or technology assessment (Mitchell et al., 1998). There are bidirectional relationships between the system and client concepts, and with the system and client concepts with both the interventions and outcomes concepts (Mitchell et al., 1998). There are no direct relationships between interventions and outcomes (Mitchell et al., 1998).

\section{The Informatics Research Organizing (IRO) Model}

The Informatics Research Organizing (IRO) model was derived from the SPO model, the QHOM, and the Systems Development Life-Cycle (SDLC) (Effken, 2003). The model in addition to the four concepts of the QHOM also includes six concepts from the SDLC. The SDLC is a process model that includes the concepts of: (1) analyze, (2) design, (3) implement, (4) maintain, (5) plan, and (6) evaluate (Effken, 2003). Effken (2003) labels the concept of 
system from the QHOM as context. Effken (2003) describes context as cultural, economic, social, and physical factors. The concept of client is described as the relevant data or information of the client and the clients' or disciplines' behaviors and characteristics (Effken, 2003).

Interventions are described as the content, structure, and flow of information and the characteristics of technology (Effken, 2003). Effken (2003) described outcomes as information, knowledge, decisions, or actions to improve cost, quality, safety, and satisfaction. There are bidirectional relationships between context and outcomes, interventions and outcomes, context and client, and client and interventions (Effken, 2003). There are unidirectional relationships going from the SDLC to the other four concepts.

\section{The Technology Acceptance Model (TAM)}

The Technology Acceptance Model (TAM) was also explored as a possible conceptual framework to guide the study. The TAM was ruled out early in the process of theory evaluation due to its limited nature of focus. The focus of the TAM is on perceived usefulness of technology and actual usage of technology (Davis, 1989; Davis et al., 1989). The purpose of this study is beyond the scope of the TAM. Although the TAM extensively examines technology usage, it is deficient in that it does not look at process or outcomes. Therefore, the TAM is not suitable for this study.

\section{Commonalities and Differences}

The three conceptual frameworks reviewed for this study have several commonalities. First and foremost, both the QHOM and the IRO model are extensions of the SPO model. Secondly, the IRO is a further extension of the QHOM. Thirdly, they all contain the concepts of structure, process, outcome, and context in one form or another. Lastly, they all contain or it is 
implicit that they contain the four components of the nursing metaparadigm. The concept of outcomes is labeled and described similarly in all of the models.

The main differences among the models can be split into two categories: (1) the naming of the concepts and (2) the relationships among the concepts. Donabediain posited that there were direct relationships between structure, process, and outcome with feedback loops from each to the other. Context is contained in the structure concept of the SPO model, whereas the QHOM splits and labels these concepts as system and client and the IRO model splits and labels these as client and context. Process is the name of the concept in the SPO model and it is labeled interventions in the QHOM and IRO model.

The relationships also differ among the models. In the SPO there are direct relationships between structure, process, and outcome and feedback loops between each of the concepts. In the QHOM there is not a direct relationship between intervention and outcomes, but in the IRO there is a bidirectional relationship between the two concepts. Another key difference between the SPO and QHOM and the IRO is that the IRO includes the SDLC and unidirectional relationships to each of the four concepts of context, outcomes, interventions, and client.

\section{Evaluation/Critique}

Donabedian's SPO model is the most parsimonious of the three models. The SPO model can almost be viewed as a metaparadigm of healthcare quality. The SPO model serves as a grounding framework for nursing informatics and nursing health services research. The strength of Donabedian's model is its adaptability and generalization to many aspects of nursing informatics research and nursing health services research. The SPO can and has been modified based on individual study needs. 
The QHOM although more parsimonious than the IRO model has no direct relationship between process and outcome. The authors state that nursing interventions do not directly impact or arenot? casual factors in regard to outcomes (Mitchell et al., 1998). The author's state that client and system variables mediate/moderate all relationships (Mitchell et al., 1998). One could argue that there is a direct relationship between some but not all nursing interventions and outcomes. It is an unfounded generalization for the authors to state that there are "never" any direct causal relationships between process and outcome. A further critique is that process is split into silos in this model and it is very difficult to place process variables in the model

The IRO model, the least parsimonious of the three models examined, presents the same challenges as the QHOM as it is derived from this model. Furthermore, it is not entirely clear how the SDLC fits into the overall model. A critique is that the relationships between the SDLC variables and the QHOM variables are not well defined by the author (Effken, 2003). It is not logical that the SDLC has only unidirectional relationships with the other four components of the QHOM. It is logical to expect that upon evaluation of outcomes or context, etc. that changes may incur in the SDLC. Additionally, the client variable is not well defined, it contains both client and discipline characteristics (Effken, 2003). Effken (2003) also views interventions as technology characteristics; one could argue that this is not an intervention. It appears as if the SDLC was placed in the QHOM in an effort to turn it into an informatics framework without much thought on how the two models relate or fit together. The author tries to justify this by saying that the concepts of the model were left intentionally abstract for the researcher to interpret in their particular study (Effken, 2003).

\section{Model Chosen for this Study/Rationale}


The conceptual framework chosen for this study is the Structure, Process, and Outcome Model of Healthcare Quality. This model was chosen as it provides grounding for the purpose of this study due to the general framework from which it is composed and ultimately is more parsimonious than the other models reviewed. The applicability of this framework to both nursing health services research and nursing informatics research is widely accepted. Kalisch \& Lee (2010) used a modified version of the model in their research of missed nursing care.

Theory derivation was utilized in the present study by using the model as a grounding framework and using the extant literature to modify the model to meet the purpose of this study. Walker and Avant (2005) consider this an appropriate method of theory derivation. This model can be used to understand the relationships that CDSS (structure) has on clinical decisionmaking and action (process) and healthcare system outcomes (outcome). In this study, the model is used to understand the relationships that nursing care reminders (structure) have on missed nursing care (process).

\section{Model Overview}

The model of the phenomena of interest includes four major concepts and several covariates that are predicted to have influence on missed nursing care (See Figure 1). The highlighted portions of the model will be of interest in this study. The major concepts of the model are electronic nursing care reminders, missed nursing care, level of use of reminders, and impact of HIT on practice (See Table 1 for conceptual definitions and empirical indicators). Conceptual definitions and empirical indicators of covariates are listed and defined in Table 2.

In the modified structure, process, and outcome model (See Figure 1 for a modified version of the model) used in this study, it is hypothesized that an EHR with nursing care reminders (structure) will directly impact registered nurse usage of nursing care reminders. The 
model suggests that the RNs perceived impact of healthcare information technology (I-HIT) on their practice will mediate the relationship between the level of RN use of the reminders and missed nursing care. Also, the model suggests that I-HIT may mediate the relationship between the use of nursing care reminders and missed nursing care. In addition there are structural covariates that may also impact missed nursing care such as staffing adequacy, patient acuity, and/or nurse characteristics. 


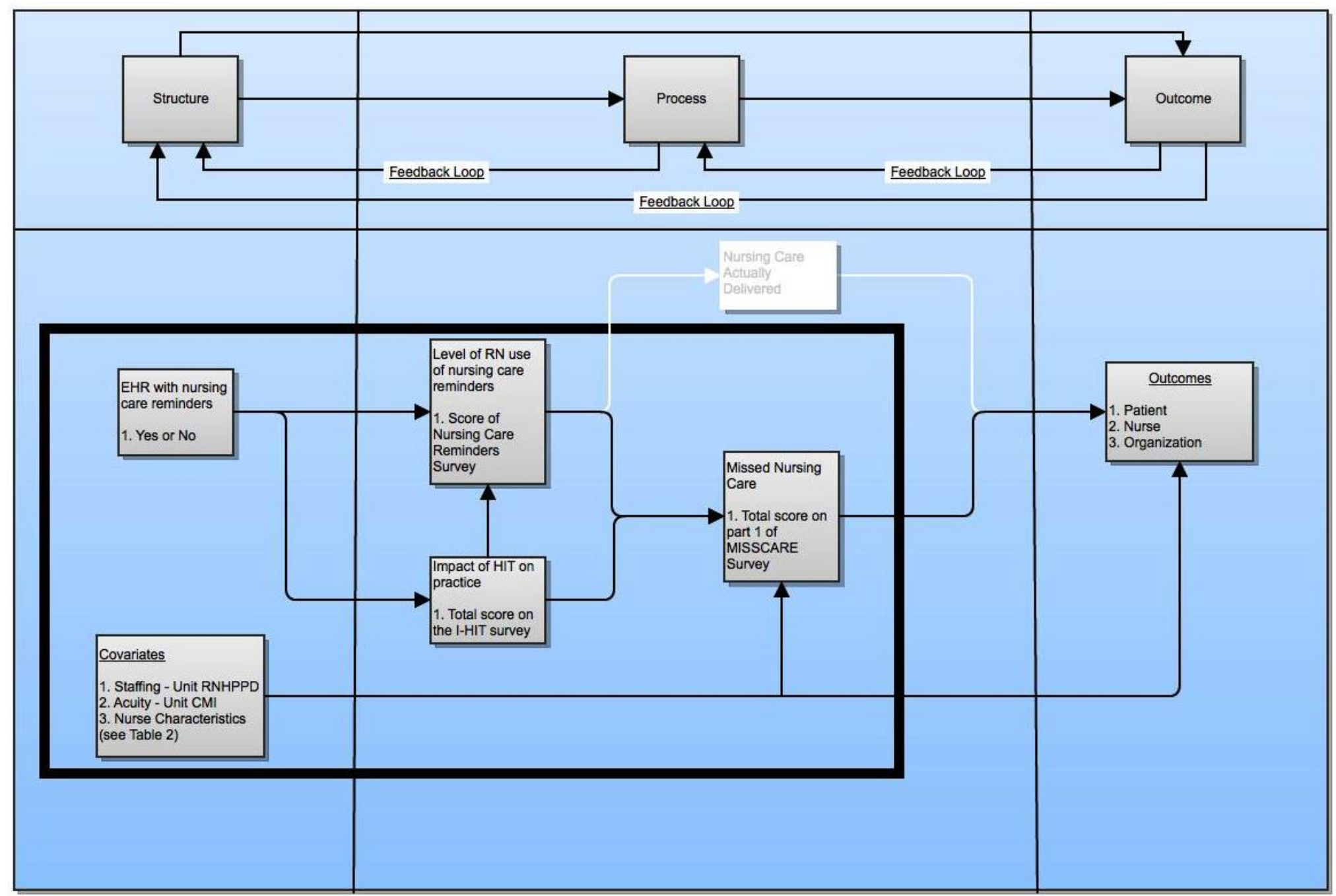

Note: $\mathrm{EHR}=$ electronic health record; $\mathrm{RNHPPD}=$ registered nurse hours per patient day; $\mathrm{CMI}=$ case mix index $\mathrm{RN}=$ registered nurse; I-HIT $=$ impact of healthcare information technology.

Figure 1. Modified Structure Process Outcome Model 
Table 1. Conceptual definitions and empirical indicators dependent and independent variables

\begin{tabular}{|c|c|c|}
\hline $\begin{array}{c}\text { Dependent } \\
\text { Variables } \\
\end{array}$ & $\begin{array}{c}\text { Conceptual } \\
\text { Definition } \\
\end{array}$ & $\begin{array}{l}\text { Empirical } \\
\text { Indicators }\end{array}$ \\
\hline Missed nursing care & $\begin{array}{l}\text { Kalisch, Landstrom, and Hinshaw (2009) } \\
\text { defined missed nursing care in a concept } \\
\text { analysis. Missed nursing care is defined } \\
\text { as any aspect of required patient care that } \\
\text { is omitted (either in part or whole) or } \\
\text { delayed. }\end{array}$ & $\begin{array}{l}\text { Missed nursing care is } \\
\text { defined operationally as: } \\
\text { The total score on the } \\
\text { MISSCARE survey } \\
\text { (Kalisch \& Williams, } \\
\text { 2009). }\end{array}$ \\
\hline Independent Variables & $\begin{array}{c}\text { Conceptual } \\
\text { Definition } \\
\end{array}$ & $\begin{array}{l}\text { Empirical } \\
\text { Indicators }\end{array}$ \\
\hline
\end{tabular}

Level of use of EHR nursing The registered nurses self-rated level of care reminders

Impact of healthcare information technology on nursing practice use of nursing care reminders in their facilities EHR.

Nurses' perceptions of the influence that HIT has on interdisciplinary communication, workflow patterns, and satisfaction with HIT applications available in hospitals.
Level of use of nursing care reminders is operationally defined as the nurses total score on the nursing care reminders survey.

Total score on the I-HIT scale (Dykes et al., 2007). 
Table 2. Conceptual definitions and empirical indicators of control variables

\begin{tabular}{lll}
\hline \multicolumn{1}{c}{$\begin{array}{c}\text { Nurse } \\
\text { Characteristics }\end{array}$} & \multicolumn{1}{c}{$\begin{array}{c}\text { Conceptual } \\
\text { Definition }\end{array}$} & \multicolumn{1}{c}{$\begin{array}{c}\text { Empirical } \\
\text { Indicator }\end{array}$} \\
RN Age & Length of time since birth date & Number of years \\
RN Gender & RN gender & Male or female \\
$\begin{array}{l}\text { Years and months of } \\
\text { experience in current role }\end{array}$ & $\begin{array}{l}\text { Years and months of practice in current } \\
\text { role }\end{array}$ & $\begin{array}{l}\text { Number of years and } \\
\text { months }\end{array}$ \\
$\begin{array}{l}\text { Years and months of } \\
\text { experience as a registered } \\
\text { nurse }\end{array}$ & Years and months as a registered nurse & $\begin{array}{l}\text { Number of years and } \\
\text { months }\end{array}$ \\
$\begin{array}{l}\text { Years and months of } \\
\text { experience with current } \\
\text { electronic health record } \\
\text { (EHR) }\end{array}$ & $\begin{array}{l}\text { Years and months of use of current } \\
\text { electronic health record (EHR) }\end{array}$ & $\begin{array}{l}\text { Number of years and } \\
\text { months }\end{array}$ \\
$\begin{array}{l}\text { Highest level of education } \\
\text { Staffing Adequacy }\end{array}$ & $\begin{array}{l}\text { Highest level of education in which a } \\
\text { degree was conferred on academic } \\
\text { transcript }\end{array}$ & $\begin{array}{l}\text { Diploma; Associates; } \\
\text { Bachelors; Masters; } \\
\text { PhD; DNP }\end{array}$ \\
$\begin{array}{lll}\text { Current employment status } \\
\text { Employment status }\end{array}$ & $\begin{array}{l}\text { Conceptual } \\
\text { Definition }\end{array}$ & $\begin{array}{l}\text { Full-time or Part-time } \\
\text { Indicator }\end{array}$ \\
\hline
\end{tabular}

Unit RN hours per patient day The number of productive hours worked (RNHPPD)

by RNs with direct patient care responsibilities divided by patient days (American Nurses Association [ANA], 2009, p. 8)
Monthly RN nhppd = total RN nh / total patient days

Quarterly RN nhppd = sum of monthly RN nhppd / \# of reporting months

(ANA, 2009, p. 8)

\begin{tabular}{ccc}
\hline Acuity & Conceptual & Empirical \\
& Definition & Indicator \\
\hline
\end{tabular}

Unit case mix index (CMI) Relative severity of illness of patient population
Sum of CMI scores of discharged patient)/(total number of discharged patients) (monthly) 


\section{Constructs}

Based on the theoretical underpinnings and the review of the literature, the main constructs of the phenomenon of interest are electronic nursing care reminders, missed nursing care, level of use of reminders, and impact of HIT on practice. Electronic nursing care reminders are defined as an electronic list, prompt, or cue of tasks or procedures that need to be completed by either the nurse or nursing assistant (NA) during their shift. An EHR is defined as an electronic database and accompanying graphical user interface which enables clinicians to document and retrieve patient care information that aids the clinician in clinical reasoning to make informed clinical decisions. This would include but is not limited to computerized physician order entry (CPOE), order and result processing and communication, patient scheduling, clinical reminders, task or work lists, and clinical documentation. The EHR must specifically contain an electronic list, prompt, or cue of tasks or procedures that need to be completed by either the nurse or nursing attendant during their shift.

Kalisch, Landstrom, and Hinshaw (2009) defined missed nursing care in a concept analysis. Missed nursing care is defined as any aspect of required patient care that is omitted (either in part or whole) or delayed. Level of use of reminders is defined as the registered nurses self-rated level of use of nursing care reminders in their facilities EHR. Impact of healthcare information technology (I-HIT) on practice is defined as the nurses' perceptions of the influence that HIT has on interdisciplinary communication, workflow patterns, and satisfaction with HIT applications available in hospitals.

\section{Relationships Between Constructs}

CDSSs influence the process of care. If a clinician uses a CDSS reminder, this may decrease the amount of missed nursing care. There are a number of factors that are hypothesized 
to influence the use of CDSS by clinicians. These factors either present, absent, or in varying combinations may contribute or influence the level of use of CDSS by clinicians. The level of use may influence working memory. Use may occur on a continuum with the clinician not using the CDSS recommendation or on the other end of the continuum of using the CDSS recommendation fully. There may be other levels of usage in between where the clinician may use the recommendation to some partial degree or for a purpose or use not intended by the designer of the system. Clinical judgment includes decision-making, action, or inaction regarding the best plan of care for patient and may result in actual care provided or missed nursing care.

\section{Credibility of the Model for Nursing Science}

Depending on the perspective chosen, the phenomenon of interest may be considered to build nursing science and the discipline. If you were viewing from a purist nursing science view, then the phenomenon would not be considered to build nursing science and the discipline because it does not utilize a pure nursing theory as the underlying framework to guide conceptualization and testing (Barrett, 2002; Rawnsley, 2003). If looking at it from a more liberal framework then the phenomenon would contribute to nursing science as the model, although not conceptualized from a nursing theory, is concerned with the impact of information systems on nursing practice, and as such, the phenomenon of interest builds both nursing science and the discipline (Barrett, 2002; Rawnsley, 2003). Furthermore, the model includes and addresses the four metatparadigm concepts of nursing: Person, environment, health, and nursing. Person is addressed as the effect of the nurses' decision to use CDSS recommendations that may influence the patients' healthcare outcomes. The model also looks at the environment in the form of structural aspects that impact the nurses' rate of adoption of guideline recommendations. Health is of importance as guideline adoption may influence the health status of the patient. 
Finally, the nurse is the focus of this model of how structural factors may influence their adoption of recommendations and the impact this has on their clinical judgment.

\section{Research Questions}

\section{Relationships}

1. Controlling for CMI, RNHPPD, and nurse characteristics examine the following relationships:

a. Is there a relationship between nurses' level of use of reminders and missed nursing care?

b. Is there a relationship between I-HIT scores and missed nursing care?

\section{Mediating Relationships}

2. Does I-HIT mediate the relationship between nursing care reminders and missed nursing care?

\section{Comparisons}

3. Controlling for CMI, RNHPPD, and nurse characteristics compare the following:

a. Do nurses who report higher levels of use of nursing care reminders have reports of decreased or less missed nursing care?

b. Do nurses who have more positive perceptions of I-HIT on their practice have reports of decreased or less missed nursing care? 


\section{Chapter II}

\section{Literature Review}

\section{Literature Review Synthesis: CDSS Usage by Nurses and Missed Nursing Care}

A review of the literature was conducted on the two major phenomena of interest in this study: (1) nursing use of CDSS and (2) missed nursing care. The literature review is presented in a synthesized format. Specific study details can be located in literature matrices created for this review (See Appendices A \& B). A synthesis of the literature of CDSS usage by nurses is presented first and followed by a synthesis of the literature of missed nursing care.

\section{Literature Review Synthesis of CDSS Usage by Nurses}

A review of the literature was conducted to determine the breadth of understanding surrounding the phenomena of nursing use of CDSS. Pub Med and the Social Science Index were two databases that were searched. The keywords used included: Nursing, CDSS, decision support, clinical decision support, reminders, use, adoption, and adherence. Key words were combined to narrow down the results. Two major informatics journals (Journal of the American Medical Informatics Association and Computers and Informatics in Nursing) were also hand searched for relevant articles. Articles were included in the review if they had a focus on nursing usage, adoption, and/or adherence to CDSS. The time period searched was open ended, as the concept of nurse use of CDSS is a relatively new concept.

The literature retrieved was synthesized into common themes. The common themes that emerged from the review of literature on CDSS usage by nurses include: (1) CDSS effectiveness, (2) Nurse factors affecting usage, (3) Patient factors affecting usage, (4) Technology and design 
factors affecting usage, and (4) Organizational factors affecting usage. The themes are listed below and are discussed with a summary synthesis of the gaps in knowledge regarding CDSS use by nurses.

\section{CDSS effectiveness}

The literature surrounding CDSS suggests that CDSS are effective to some extent. The majority of effectiveness studies that have been conducted examined physician performance. The effectiveness of CDSS in improving nursing clinical practice is not well known. Hunt et al. (1998) reported in a systematic review of controlled trials that CDSS effects on performance were assessed in 65 studies and of those 65, 43 found benefits (66\%). Garg, et al. (2005) reported in a systematic review of 100 studies that CDSS improved practitioner performance in 62 or $64 \%$ of studies. Improved performance was associated with a CDSS that automatically prompted users vs. those that the user has to initiate (success in $73 \%$ vs. $47 \%$ of the studies) and in studies in which authors developed the CDSS software (success in $74 \%$ vs. $28 \%$ of the studies) (Garg et al., 2005). Kawamoto et al. (2005) reported in a systematic review of 70 studies that decision support systems significantly improved clinical practice in $68 \%$ of those trials. The study also reviewed features of CDSS that improved clinical practice. They reported four system features identified as contributing to clinical improvements: (1) automatic provision of decision support as part of clinician workflow, (2) provision of recommendations rather the just assessments, (3) provision of decision support at the time and location of decision making, and (4) computer based decision support. Of the 32 systems possessing all four features, 30 (94\%) improved clinical practice (Kawamoto et al., 2005).

Randell, Mitchell, Dowding, Cullum, and Thompson (2007) conducted a systematic review of the effectiveness of CDSS in improving nursing care. Of the studies reviewed, eight 
were included in the final review. None of the studies found an impact of CDSS on patient outcomes. CDSS was found to be effective in two studies that looked at triage. The CDSS improved performance as it reduced physician workload when nurses used the CDSS. One study reviewed suggests that CDSS is detrimental to patient outcomes, while another suggested it is beneficial for some outcomes (Randell et al., 2007). The authors concluded that benefits of CDSS are inconclusive and need further investigation (Randell et al., 2007). Titler (2008) reported in a integrative review on evidence based practice implementation that CDSSs have been found to be effective in aligning practice with the evidence base. Titler (2008) also commented that there is still a need to understand the best way of delivering evidence through electronic health records.

\section{Nurse factors affecting usage}

There is limited attention placed on clinician factors that may influence the adoption of CDSS recommendations. Alquraini, Alhashem, Shah, and Chowdhury (2007) conducted a survey study to determine nurse's attitudes towards computerization in Kuwait. The authors found that there are differences in attitudes regarding clinical information systems in relation to nationality, level of education, pervious experiences in computer use, and computer skills. The study also reported that gender (females), nationality (non-Kuwaiti), higher education levels, and longer duration of computer use were statistically significant predictors of positive attitudes towards computerized health information systems (Alquraini, Alhashem, Shah, \& Chowdhury, 2007). Dowding et al. (2009b) conducted a multi-site case analysis to determine nurses' use of CDSS. Dowding et al. (2009b) reported that nurses' experience with decision and technology affected how they used a decision support system and whether or not they over-rode recommendations made by the system. 
O'Cathain, Munro, Armstrong, O'Donnell, and Heaney (2007) conducted a survey study examining nurses' attitudes toward risk and the effect this had on clinical decision-making. O'Cathain et al. (2007) reported that nurses' attitudes toward risk varied greatly. Using multilevel modeling and after case-mix adjustment, there was some evidence that nurses' attitudes towards risk affected decisions but this was inconsistent and unconvincing. Much of the decision-making remained unexplained by the models. Weir et al. (2007) conducted an observational and survey studying examining clinicians' information management strategies in regard to computerized order entry. The authors noted that in order to promote CDSS adoption, the CDSS must be designed to allow for fast and accurate decisions.

Titler (2008) reported that characteristics of users such as education, practice specialty, and views of innovativeness might influence adoption of EBP although findings are inconclusive. She also stated that EBP must be aligned with workflow to foster adoption. It was also noted that nurses' disposition towards critical thinking is positively correlated with research use. In an integrative review of patient care technology and safety, Powell-Cope, Nelson, and Patterson (2008) reported that characteristics of nurses that moderate and mediate the use of technology in practice include: age, experience, mindset about technology/attitudes, selfefficacy, attention, fatigue, sensory inputs, perception, goals, intention to use, and knowledge.

Courtney, Alexander, and Demiris (2008) examined existing literature from the Novice to Expert Nursing Framework to aid in HIT implementation for nurses. They reported that the CDSS must fit within the workflow of the clinician if they are to adopt the recommendations. They must feel that CDSS addresses a particular and important concern for clinical practice (Courtney, et al., 2008). Randell and Dowding (2010) conducted a multiple site case study that examined organizational influences on nurses' use of CDSSs. A key theme that emerged from 
the analysis indicated that in order for a system to be successful clinician engagement is necessary. Choi, Choi, Bae, and Lee (2011) conducted a qualitative study using focus groups to examine type and content of CDSSs that improved patient safety. The nurses consistently stated that CDSSs could contribute to improving nursing outcomes by standardizing nursing care. The nurses wanted a system to remind them of scheduled care, assesses deleterious changes in patient condition, and acuity level.

Dowding et al. (2009a) conducted a secondary analysis of survey and observational data to examine the impact of nurse experience on CDSS usage. Dowding, et al. (2009a) reported that nurses tended to use the CDSS recommendations when they first started working in a clinic and had little experience in their role. As the nurses gained more experience, they were less likely to follow the guidance contained within the CDSS and use their own professional judgment and override recommendations if they felt they were not appropriate. Experienced nurses still valued CDSS and utilized it with unfamiliar cases or as a memory aid. They used the CDSS as a “safety-net". Cho, Staggers, and Park (2010) conducted a repeated measures study to examine nurses' responses to different amounts of information in CDSSs. The authors reported that user preferences for display of information in CDSSs differed significantly between novice and expert nurses. The novice nurses wanted to see all possible problems for patients, whereas expert nurses only wanted to see the top five problems.

Ernesater, Holstram, and Engstram (2009) conducted a qualitative study using interviews to determine telehealth nurses use of CDSSs and how they influence their work. Enrnesater et al. (2009) reported that nurses experienced their work with decision support as supporting, inhibiting at time, and quality improving. The main theme identified is that the system strengthened their practice but at the same time controlled and inhibited their professional 
judgment. Specifically that the system was incomplete and sometimes in conflict with their own opinion, which felt controlling. They preferred working with the system but described that the CDSS could not replace their knowledge and competence and that it should be considered complementary to ensure the quality of tele-nursing.

Weber, Courtney, and Benham-Hutchins (2009) conducted a qualitative study using interviews to determine how CDSSs facilitate communication between physicians, nurses, patients, and family members in intensive care units. Weber et al. (2009) reported that nurses and physicians are motivated to use a CDSS when it allows them to forecast potential outcomes of decisions prior to actually making those decisions. When the system decisions are congruent with that of the clinician prediction, the clinicians are more likely to incorporate the system recommendation into practice. Nurses were also more apt to use the system once they found out they could use the data to influence physician decisions. The system was used to support or back-up the clinical decisions that were made. Campion, Waitman, Lorenzi, May, and Gadd (2011) conducted an observational study to determine barriers and facilitators of a computerbased intensive insulin therapy CDSS. They noted that a facilitator to successful use of CDSS by nurses is that it has to be aligned with the nurses' clinical judgment.

Randell, Mitchell, Thompson, McCaughan, and Dowding (2009) conducted a secondary analysis of interviews and observations to examine the use of CDSS to inform nurse decisionmaking. Randell et al. (2009) reported that many of the nurses felt there was a need for decision tools to ensure consistency in practice. Nurses stated that they always followed the guidelines and they had memorized them. They stated they were working from the guidelines even when not looking at them. Working with the guidelines occurred infrequently. Guidelines would sometimes be checked after the event to ensure that they had taken the correct action. The nurses 
stated that they had helped develop the guidelines and they wanted national guidelines to be user-friendlier and to be able to adapt them to meet their needs.

\section{Patient factors affecting usage}

The literature review yielded very little information on how patient characteristics influence CDSS guideline adoption by registered nurses. In two studies, it was reported that when nurses encountered patients with more complex cases, this often necessitated the need to use the CDSS guidelines (Dowding et al., 2009a; Dowding et al., 2009b). It was also noted that when a nurse was not familiar with a patient they often utilized the CDSS recommendations (Dowding et al., 2009a; Dowding et al., 2009b). Randell, Mitchell, Thompson, McCaughan, and Dowding (2009) reported that nurses when encountering unfamiliar patient cases often utilized CDSS guidelines.

\section{Technology and design factors affecting usage}

Several studies were identified that addressed the system design and the impact that this may have on nurse use of CDSS recommendations. Saleem et al. (2005) conducted an observational study to identify barriers and facilitators to CDSS usage by nurses. Saleem et al. (2005) reported that system design barriers to using the system optimally included: lack of coordination between nurses and providers, using the reminders while not with the patient which impaired data acquisition and/or implementation of recommended actions, workload, lack of reminder flexibility, and poor interface usability. Facilitators to using the system optimally included: limiting number of reminders at a site, strategic location of the computer workstations, interaction of reminders into workflow, and ability to document system problems and receive prompt administrator feedback. Marshall, West, and Aitken (2011) conducted an instrumental case design study to examine critical care nurse's preferred information sources for decision 
making. The nurses in the study preferred information sources that are from other nurses and colleagues. The nurses reported that electronic resources were not utilized because they were perceived as less accessible and took too much time to access information.

In another study conducted by Saleem et al. (2007) designed to address barriers regarding CDSS adoption, it was reported that modest design modifications to existing clinical reminder software positively impacted variables that likely increase the willingness for first-time nursing users to adopt and consistently use clinical reminders. Powell-Cope, Nelson, and Patterson (2008) reported that technology characteristics that influence technology use by nurses include: reliability, validity, ergonomic design, output display, input mechanism, interface, and compatibility with other technologies. Campion et al. noted that a lack of reminders and inaccurate user interface design are barriers to nurses' use of CDSSs. Cho et al. (2010) reported in a study examining the amounts of CDSS information delivered to nurses, that a facilitator to use was a CDSS that is well-organized and facilitated patient problem identification. A barrier identified was that the nurses felt that the data input into the CDSS was tedious and difficult and the display for data input was too complicated. The nurses also felt that automatic suggestions and data driven approaches to assessments were desirable features of the system.

O'Neill, Dluhy, Hansen, and Ryan (2006) reported in a study that examined the design of CDSS to meet nurses needs, that the nurses expressed the need to "trust" the information. They wanted to know where the information came from. This is a significant finding as it points to the need to make evidence-based process to build practice maps transparent to users. Campion et al. also noted that a facilitator to successful CDDS usage included the nurse's trust in the recommendations made by the CDSS. 
Dowding et al., (2009b) reported that the ability of nurses to adapt the technology also affected use. Some nurses felt that after repeated use of the algorithms, they had learned them and found them of little value. Some nurses discussed how they tailored the algorithms by directing the patient to answer questions in a specific order to get to a specific recommendation. Choi et al. (2011) reported that nurses wanted a system that allowed customized guidelines for patients.

\section{Organizational factors affecting usage}

Organizational factors have also been identified as influencing use of technology innovations such as CDSS guidelines. In a qualitative study examining chief nurse executives clinical information system (CIS) readiness and success factors, Piscotty and Tzeng (2011) reported that the majority of CNE responses were classified into the thematic areas of: champion support, staff preparation for change, training, organizational alignment, and planning, with the themes of culture, funding, access, usability, decision-making, and communication having the fewest responses. A new theme not previously identified in the model but clear in the CNE responses is the lack of vendor support.

Titler (2008) reported that members of a social system determine how fast and widely EBP guidelines are adopted and that auditing and feedback have shown a positive effect on changing behavior. Titler also suggested that organizational structure and factors may affect adoption and that leadership support is critical for promoting the use of EBP. Powell-Cope, Nelson, and Patterson (2008) when describing a model of technology use by nurses reported that organizational factors that may influence use include: policies, resources, culture, social norms, management commitment, training programs, and employee empowerment. Simlarly, Randell and Dowding (2010) reported that key themes to successful CDSS use include: adequate 
resources, characteristics of the system, and adequate training. Additionally, the nurses reported that a supportive environment and desire to improve quality are keys to successful implementation

\section{Nurses Use of CDSS Summary Synthesis}

The literature review on CDSS was synthesized into four common themes or factors that influence nurses use of CDSS. These four areas are: clinician factors, patient factors, design factors, and organizational factors. These four areas were readily supported by the literature (See Table 3). Additionally the review readily revealed that there have been limited studies that have addressed CDSS and nursing. The majority of research on CDSS has tended to focus on physician usage and adoption. There has also been limited research on the adoption of clinical guideline content delivered through a CDSS.

Nurse CDSS usage factors were identified by Dowding et al. (2009a) and Dowding et al. (2009b) as an area that needs further research and exploration. The authors specifically stated that the relationship between nurse experience, knowledge base, and CDSS usage needs to be further studied. Randell, Mitchell, Dowding, Cullum, and Thomopson (2007) conducted a systematic review of nursing CDSS usage. Randell et al. (2007) reported that the evidence of CDSS usage to support nursing practice is limited. In the review, they were only able to locate eight studies that addressed the effects of CDSS on nursing performance and patient outcomes. Staggers, Weir, and Phansalkar (2008) conducted an integrative review of CDSS for nursing. Staggers et al. (2008) identified three gaps based on a review of literature surrounding CDSS and nursing. They noted that there is a lack of understanding of the knowledge development of CDSS to support nursing practice. The knowledge representation of nurse clinical decision-making in 
CDSS is unknown. They also noted that the delivery of CDSS content must be further explored in order to support nurses' clinical workflow. In their review, only 31 studies were identified as relevant and only 13 focused directly on nursing. 
Table 3. Synthesis of key finding: CDSSs literature review

\begin{tabular}{|c|c|}
\hline $\begin{array}{l}\text { Nursing Factors } \\
\text { Affecting Usage }\end{array}$ & Study \\
\hline Aligned with workflow & $\begin{array}{l}\text { Campion et al. (2011); Choi et al. (2011); } \\
\text { Courtney et al. (2008); Ernesater et al. (2009); } \\
\text { Kowamoto et al. (2005); Piscotty et al. (2011); } \\
\text { Saleem et al. (2005); Randell et al. (2010); } \\
\text { Titler (2008); Weber et al. (2009); Weir et al. } \\
\text { (2007) }\end{array}$ \\
\hline Experience with system & $\begin{array}{l}\text { Alquraini et al. (2007); Dowding et al. (2009a; } \\
\text { 2009b) }\end{array}$ \\
\hline Age & $\begin{array}{l}\text { Alquraini et al. (2007); Powell-Cope et al. } \\
\text { (2008); Titler (2008) }\end{array}$ \\
\hline Education & Alquraini et al. (2007); Titler (2008) \\
\hline Gender & Alquraini et al. (2007) \\
\hline Experience in current role & $\begin{array}{l}\text { Cho et al. (2010); Dowding et al. (2009a; } \\
\text { 2009b); Powell-Cope et al. (2008) }\end{array}$ \\
\hline Critical thinking & Titler (2008) \\
\hline $\begin{array}{l}\text { Patient Factors } \\
\text { Affecting Usage }\end{array}$ & Study \\
\hline Unfamiliar patient & $\begin{array}{l}\text { Dowding et al. (2009a; 2009b); Randell et al. } \\
\text { (2007) }\end{array}$ \\
\hline Complex patient & $\begin{array}{l}\text { Dowding et al. (2009a; 2009b); Randell et al. } \\
\text { (2009) }\end{array}$ \\
\hline
\end{tabular}

(continued) 
Table 3. Synthesis of key finding: CDSSs literature review (continued)

\begin{tabular}{|c|c|}
\hline $\begin{array}{l}\text { Organizational Factors } \\
\text { Affecting Usage }\end{array}$ & Study \\
\hline Leadership & $\begin{array}{l}\text { Piscotty et al. (2011); Powell-Cope et al. } \\
\text { (2008); Randell et al. (2010); Titler (2008) }\end{array}$ \\
\hline Organization structure & Titler (2008) \\
\hline Champions & $\begin{array}{l}\text { Piscotty et al. (2011); Randell et al. (2010); } \\
\text { Titler (2008) }\end{array}$ \\
\hline Training & $\begin{array}{l}\text { Piscotty et al. (2011); Randell et al. (2010); } \\
\text { Powell-Cope et al. (2008) }\end{array}$ \\
\hline Resources & Randell et al. (2010) \\
\hline Vendor support & Piscotty et al. (2011) \\
\hline $\begin{array}{l}\text { Technology and Design } \\
\text { Factors Affecting Usage }\end{array}$ & Study \\
\hline Interface usability & $\begin{array}{l}\text { Campion et al. (2011); Powell-Cope et al. } \\
\text { (2008); Saleem (2005; 2007) }\end{array}$ \\
\hline Flexibility & $\begin{array}{l}\text { Cho et al. (2010); Choi et al. (2011); Dowding } \\
\text { (2009a; 2009b); Powell-Cope et al. (2008); } \\
\text { Saleem et al. (2005; 2007) }\end{array}$ \\
\hline Access & Marshall, et al. (2011); Saleem et al. (2005) \\
\hline Knowledge-base & $\begin{array}{l}\text { Cho et al. (2010); Campion et al. (2011); } \\
\text { O'Neill et al. (2006); Powell-Cope et al. (2008) }\end{array}$ \\
\hline
\end{tabular}




\section{Literature Review Synthesis of Missed Nursing Care}

A review of the literature was conducted to determine the breadth of understanding surrounding the phenomena of missed nursing care. Pub Med and the Social Science Index were two databases that were searched. The keywords used included: Nursing, care, missed, rationed, unfinished, and omission. Key words were combined to narrow search results to relevant articles that focused specifically on care omission of nurses. Manuscripts addressing omissions of nursing care, unfinished nursing care, rationed nursing care, and missed nursing care were included for review and synthesis. The time period searched was open ended, as the concept of missed nursing care is a relatively new concept.

The literature retrieved was synthesized into common themes. The common themes that emerged from the review of literature on missed nursing care include: (1) General knowledge of missed nursing care, (2) Hospital and nursing unit variation in missed nursing care, (3) Nurse and patient perceptions regarding missed nursing care, (4) Missed nursing care and teamwork, (5) Missed nursing care and job satisfaction, (6) Missed nursing care and staffing adequacy, and (7) Missed nursing care and outcomes. Each of the seven areas is discussed below with a summary synthesis of the gaps in knowledge regarding missed nursing care.

\section{General knowledge of missed nursing care}

The concept of missed nursing care was first explored in a qualitative study conducted by Kalisch (2006). Using focus groups with registered nurses (RNs), licensed practical nurses (LPNs), and nursing assistants (NAs) the purpose of the study was to find common types of missed nursing care and the subsequent reasons behind them. The nurses in the study responded that they were not always able to provide the needed care for each patient. The participants 
reported a high level of guilt and regret when not able to provide all of the care their patients required.

Through analysis of the focus group transcripts nine themes of regularly missed nursing care emerged. These themes are: (1) ambulation, (2) turning, (3) delayed or missed feedings, (4) patient education, (5) discharge planning, (6) emotional support, (7) hygiene, (8) intake and output documentation and (9) surveillance. Similarly, seven themes for the reasons for missed care emerged from the analysis. These themes are: (1) too few staff, (2) time required for a nursing intervention, (3) poor use of existing staff resources, (4) not my job syndrome, (5) ineffective delegation, (6) habit, and (7) denial.

Missed nursing care was formally defined in a concept analysis conducted by Kalisch, Landstrom, and Hinshaw (2009). A concept analysis was needed as no definition of missed care was found in the extant nursing literature. The authors noted that other studies examined effects of missed care, but did not address it directly (Kalisch et al., 2009). Missed nursing care is conceptualized as a universal phenomenon and is generalizable to multiple clinical settings. Antecedents to missed care include: labor resources, material resources, and communication and teamwork, which interact with the nursing process and the nurse's own internal processes. Potential ramifications of missed nursing care are threats to patient safety. Thus, missed nursing care is defined as any aspect of required patient care that is omitted (either in part or whole) or delayed (Kalisch, et al., 2009).

Kalisch, Landstrom, and Williams (2009) conducted a descriptive study to determine what nursing care is commonly missed and the reasons why care is missed. Kalisch et al. (2009) examined missed care missed according to the Nursing Process and found that assessment was missed $44 \%$ of the time, intervention $73 \%$ of the time, and planning $71 \%$ of the time. The six 
most commonly missed nursing care items were: (1) ambulation (84\%), (2) assessing effectiveness of medications (83\%), (3) turning (82\%), (4) mouth care (82\%), (5) patient teaching (80\%), and (6) timeliness of PRN (as needed) medication administration. The least commonly missed nursing care items were patient assessments (17\%) and bedside glucose monitoring $(26 \%)$.

When examining the reasons for missed care, Kalisch et al. (2009) reported the three most commons reasons for missed care included: (1) labor resources (85\%), (2) material resources (56\%), and (3) communication (38\%). In regard to labor resources the four items that make up this category: (1) unexpected rise in patient acuity, (2) urgent patient situations, (3) level of staffing, and (4) inadequate number of assistive personnel were reported as common reasons by greater than $80 \%$ of the respondents.

Lawless (2010) examined the similar concept of care rationing in a survey that examined indicators of workplace quality. Lawless defined care rationing as any situation in which care is delayed, omitted, or not completed at a satisfactory level due to workload pressures. In regard to rationed care, nurses reported 11 common patient care activities that were all ranked as often or very often rationed. The authors did not list the 11 common themes but indicated they included items such as: implementing planned care, patient surveillance, and completing documentation. When care was rationed due to workload pressures the nurses stated they adapted by working at an increased pace, missing breaks, staying past shift, taking work related stress leave, changing jobs, or leaving nursing.

\section{Hospital and nursing unit variation in missed nursing care}

Kalisch et al. (2009) also examined types and reasons for missed care across hospitals and units. The results indicated that there were consistently no significant differences in the 
number of omissions of assessments and basic care. There were differences in interventions and missing plans across hospitals. Reasons for missed care revealed no significant difference in terms of labor resources. There were significant differences in communication and material resources.

When looked at by service, renal units had significantly more missed care in the areas of assessment, interventions, basic care, and planning compared to other units. Reasons for missed care in renal units showed no significant difference in material and labor resources, but renal units had more communication problems. Additionally, associate degree nurses (ADNs) reported more missed care than baccalaureate nurses $(\mathrm{BSN})$ or diploma nurses.

Al-Kandari and Thomas (2009) conducted a survey study to examine factors that contribute to nursing task incompletion in five Kuwait general hospitals. Nursing task incompletion is a nursing care omission. The most common nursing activities that nurses were unable to complete included: (1) comfort talk with patient and family, (2) adequate documentation of nursing care, (3) oral care, (4) routine catheter care, and (5) starting or changing IV fluid on time. The results indicated that nursing activities were completed more often when the patient to nurse ratio was less than five. Bivariate analysis was used to examine the relationship between task completion and demographic variables. The analyses indicated that the nurses' educational background and age were related to completion of nursing care activities. Gender had no influence on nursing care activity completion.

Kalisch, Tschannen, Lee, and Friese (2011) in a survey study examined variation in missed nursing care across ten hospitals. In regard to the amount and type of missed nursing care that was frequently or always missed: (1) ambulation $(32.7 \%),(2)$ attendance at care conferences (31.8\%), and (3) mouth care $(25.5 \%)$ were the most commonly reported. In regard to items 
occasionally or rarely missed: (1) patient assessments (97.7\%), glucose monitoring (97.6\%), and vital signs $(95.8 \%)$ were the most commonly reported.

Similarly, the reasons for missed care most commonly reported included: (1) inadequate labor resources $(93.1 \%),(2)$ material resources $(89.6 \%)$, and (3) communication $(81.7 \%)$. In regard to the labor resources category an unexpected rise in acuity or patient volume was the most commonly $(94.9 \%)$ reported reason for missed nursing care. Medications missing in materials resources (94.6\%) and communication, specifically unbalanced patient assignments (91\%) were also commonly reported reasons for missed nursing care.

The authors also examined relationships among unit and staff variables (Kalisch et al., 2011). Eight variables were found to be associated with increased amounts of missed nursing care. These variables include: (1) being female, (2) being older, (3) being a RN, (4) working day shift, (5) having more experience, (6) absenteeism, (7) perceived staffing adequacy, (8) and caring for more patients on the previous shift. Education level, weekly work hours, and type of unit were not significantly associated with increased missed nursing care.

Adjusted regression analysis was used to determine significant predictors of missed care (Kalisch et al., 2011). The significant predictors in the model were: (1) NAs with fewer years of experience reported less missed care compared to RNs, (2) night shift workers reported less missed care than day shift staff, (3) nursing staff who missed two or more shifts in the past three months reported more missed care, (4) those who cared for more patients in the previous shift reported more missed care, and (5) nursing staff that perceived staffing as adequate reported less missed care. Age and gender were not significant predictors of missed care in the regression model. 
Kalisch, Gosselin, and Choi (2012) examined the differences in missed nursing care among units with the most missed nursing care and those with the least missed nursing care. Transcripts from focus groups with RNs were analyzed. There were 10 themes that emerged that described the differences between units with high and low amounts of missed nursing care. The 10 themes include: (1) staffing levels and adaptability, (2) communication, (3) collective orientation, (4), backup, (5) monitoring, (6) leadership, (7) long tenure, (8) unit layout, (9) trust, and (10) accountability.

\section{Nurse and patient perceptions regarding missed nursing care}

Kalisch (2009) conducted a survey study that examined RNs and NAs perceptions of the elements of missed nursing care and their reasons. RNs reported more missed care than NAs. Perceptions for missed care were only similar for five nursing care activities: (1) medication administration, (2) PRN (as needed) medication requests, (3) patient assessments, (4) focused reassessments, and (5) teaching about discharge planning. Registered nurses reported significantly more missed care for the remaining 19 items on the MISSCARE survey (See Appendix $\mathrm{C}$ for a list of all missed care items).

In regard to the reasons for missed care, staff and labor resources were reported the most by both RNs and NAs, but RNs felt this was a reason for more missed care than NAs. Registered nurses also identified an unexpected rise in patient volume, urgent patient situations, and admissions and discharges more frequently than NAs. Registered nurses and NAs did not differ in their reasons for missed care related to level of staffing and number of assistive personnel.

Gravlin and Bittner (2010) conducted a survey to examine RNs and NAs reports of missed nursing care. The most frequently missed nursing care activities were: (1) ambulation, (2) turning, (3) feeding, and (4) mouth care. The most commonly reported reasons for missed care 
were related to labor resource factors and included: (1) an unexpected rise in patient acuity or volume, (2) inadequate number of assistive personnel, (3) heavy discharge/admission activity, (4) level of staffing, and (5) urgent patient situations.

The three common reasons for missed nursing care reported by RNs were related to nurses' ability to manage patient flow and rapidly changing patient and unit needs (Gravlin and Bittner, 2010). Additionally, RNs cited communication with the NA, specifically that care was not completed as a factor for increased missed nursing care. RNs also noted that communication breakdowns among healthcare personnel led to an increase in missed nursing care. An additional finding of this study was that $88 \%$ of nurse managers stated that staff had reported a nursing care omission to them. The managers that received reports of nursing care omissions, $66.7 \%$ of them reported the occurrence of the omission as frequent (Gravlin and Bittner, 2010).

Kalisch, McLaughlin, and Dabney (2012) explored elements of missed nursing care that patients could report and the patients' perceptions on the extent and type of missed nursing care they experienced. A qualitative phenomenological design was used in the study. Patients were interviewed to answer two questions: (1) What is the patient's ability to assess elements of nursing care? and (2) To what extent care was missed? Items of missed care that patients could report were categorized into three areas (fully reportable, partially reportable, and not reportable.). Missed nursing care items were further categorized into the areas of frequently missed, sometimes missed, and rarely missed.

Fully reportable frequently missed nursing care activities that patients could identify included: mouth care, listening, and being kept informed. Nursing care activities that were sometimes missed included: response to call lights, response to alarms, meal assistance, and pain medication and follow-up. Bathing was reported as rarely missed. Partially reportable frequently 
missed nursing care activities that patients could report included: ambulation, discharge planning, and patient education. Nursing care activities that were sometimes missed included: medication administration and repositioning. Vital signs and hand washing were identified as rarely missed. Missed nursing care activities that patients were unable to report included patient assessment, surveillance, and IV site care.

\section{Missed nursing care and teamwork}

Kalisch (2009) conducted focus groups to examine the underlying teamwork issues between RNs and NAs and the relationship to reasons for missed nursing care. The RNs felt there was not enough staff. They also reported that the NAs did not have an adequate knowledge base to understand the impact that missed nursing care activities have on patient outcomes. The RNs also stated that NAs would refuse to provide care. An additional theme identified by RNs was poor communication and that the NAs do not give them complete patient reports. In regard to the NAs perceptions, they felt that the RNs didn't believe them when they would report they completed a nursing care activity. The NAs also reported that they did not have enough time to complete nursing care activities. Additionally, the NAs stated that the RNs do not listen to them, and that they received no or late reports on their patients from the RNs.

Kalisch and Lee (2010) conducted a descriptive study to examine if the level of teamwork is related the amount of missed nursing care. Teamwork scores varied significantly by unit, intensive care units (ICUs) had higher teamwork scores than the other units. A negative relationship between missed care mean scores and teamwork was significant $(\mathrm{r}-.37, \mathrm{p}<.01)$, indicating that higher teamwork scores are associated with less missed nursing care. Kalisch and Lee (2010) also reported that more missed care was associated with lower scores in: (1) trust, (2) having a team orientation, (3) having a shared mental model, and (4) team leadership. 
Multiple regression analysis was conducted to examine predictors of missed care. Registered nurses perceived more missed care than NAs. Compared to staff working on the unit with less than six months of experience, staff that reported five or more years of experience reported more missed nursing care. Additionally staff that perceived staffing as adequate reported less missed nursing care.

\section{Missed nursing care and job satisfaction}

Rochefort and Clarke (2010) conducted a correlational survey examining the relationships between work environment, care rationing, job outcomes, and quality of care on neonatal units. The results indicated that more favorable work environments were related to lower levels of nursing care rationing. Specifically rationing of parental teaching, support, infant comfort care, discharge planning, and care coordination were 11\% lower when nurse staffing and resource adequacy were rated one point higher. There was a $5.7 \%$ and $7.7 \%$ reduction in rationing of life support, technologically oriented nursing care, and patient surveillance between the best and worst ratings of nurse staffing and resource adequacy. A $4 \%$ per unit increase in nurse-physician relationships was related to a reduction in rationing of life support, technologically oriented nursing care, and patient surveillance. Rationing of care was an explanatory effect in the relationship between nurse-physician relationships and emotional exhaustion.

Tschannen, Kalisch, and Lee (2010) conducted a descriptive study examining the relationship between missed nursing care and $\mathrm{RN}$ intention to leave and turnover. Bivariate analysis indicated that larger amounts of missed care were associated with higher turnover rates. Larger amounts of missed care were associated with greater intention to leave. Multiple 
regression analysis indicated that missed care was not found to be a predictor of nurse turnover, but was found to be a predictor of intention to leave.

Kalisch, Tschannen, Lee, and Salsgiver (2011) conducted a survey to explore the impact of missed nursing care on job satisfaction of RNs and NAs. Nursing staff that reported less missed nursing care had a greater satisfaction with their job and occupation. Regression analysis was used to determine predictors of satisfaction. In the two models tested, staffing adequacy and missed care were significant predictors of satisfaction. The analysis also revealed that perceptions of staffing adequacy were a significant predictor for both satisfaction variables (job and occupation). Additionally, it was found that nurses on ICUs were more satisfied than those on rehabilitation units.

\section{Missed nursing care and staffing adequacy}

Sochalski (2004) conducted a survey that examined the relationship between nursing staffing and the quality of nursing in hospitals. One concept examined in this study was "unfinished care", defined as the number of tasks left undone (Sochalski, 2004). Unfinished care, a related concept to missed nursing care is also considered a care omission. Sochalski (2004) reported that the quality of nursing care is significantly associated with the number of patients the nurse cares for, rates of unfinished care for the patients, and frequency of patient safety problems.

Kalisch, Tschannen, and Lee (2011) conducted a descriptive study with the aim of examining the relationship between staffing adequacy and missed nursing care. In bivariate analysis, hours per patient day (HPPD) and registered nurse HPPD (RNHPPD) were negatively associated with missed care. The higher the hours per patient day, the less missed nursing care 
reported. Greater absenteeism was associated with higher reports of missed nursing care. Higher case mix index (CMI) was associated with lower reports of missed nursing care.

Multiple regression analysis was used to determine predictors of missed nursing care. Hours per patient day (HPPD) was a significant predictor of missed nursing care and along with the other variables in the model, experience (>5 yrs), absenteeism, CMI, and 9 dummy hospital variables, the total variance explained was $29.4 \%$. The only variable in the model that was significant was HPPD. Thus, missed nursing care may partially explain the relationship between staffing levels and patient outcomes.

\section{Missed nursing care and outcomes}

Schubert, Glass, Clarke, Aiken, Schaffert-Witvliet, Sloane, and De Geest (2008) conducted a multi-hospital survey to examine the relationship of rationing of nursing care and patient outcomes. Overall, nurses in the study reported low levels of omitted care. Multilevel multivariate regression analysis indicated that implicit rationing of nursing care was a significant predictor of all six patient outcomes studied. The six patient outcomes examined in the study are: (1) patient satisfaction, (2) medication errors, (3) patient falls, (4) nosocomial infections, (5) critical incidents, and (6) pressure ulcers.

Kalisch, Tschannen, and Lee (2012) conducted a descriptive study examining the relationship between missed nursing care, staffing, and patient falls. Bivariate analysis indicated that HPPD was negatively associated with falls and higher missed care scores were associated with higher fall rates. Additional significant correlations were found related to the following elements of missed nursing care: (1) ambulation, (2) each shift patient assessment, (3) call light response, and (4) toilet assistance. Focused reassessment and CMI were not significantly associated with falls. Three regression analyses were conducted to examine if missed nursing 
care mediated the relationship between HPPD and patient falls. The analyses indicated that missed nursing care is a mediator of the relationship between HPPD and falls.

\section{Missed Nursing Care Summary Synthesis}

The literature review conducted on missed nursing care was synthesized into seven common themes. The common themes that emerged from the review of literature on missed nursing care include: (1) General knowledge of missed nursing care, (2) Hospital and nursing unit variation in missed nursing care, (3) Nurse and patient perceptions regarding missed nursing care, (4) Missed nursing care and teamwork, (5) Missed nursing care and job satisfaction, (6) Missed nursing care and staffing adequacy, and (7) Missed nursing care and outcomes. These seven themes were readily supported by the literature (See Table 4).

Three main gaps were identified through the review of the literature. The three gaps are: (1) greater understanding of the impact on patient outcomes, (2) what are the specific or granular aspects of the labor resource component that leads to missed care, and (3) interventions to decrease missed care. Although, a relationship between patient outcomes and missed nursing care has been demonstrated, additional studies need to be conducted to determine the impact that missed nursing care has on additional patient outcomes such as cost and length of stay.

In regard to the labor resource component, a primary reason for missed care, a granular approach is needed to examine specific reasons for missed care in this component. One hypothesis is that increased patient acuity and volumes may lead to more frequent distractions and interruptions in care (Bittner et al., 2011). These distractions and interruptions may impact the RNs working memory thus contributing to an increase in missed nursing care. The third gap is that no specific interventions have been developed to address missed nursing care. One suggestion is the use of electronic care reminders delivered to nurses in EHRs. This intervention 
is related to possible frequent interruptions and distractions related to inadequacy of labor resources, which may remind nurses to complete care that may be missed if no reminder is present. 
Table 4. Synthesis of key findings: Missed nursing care literature review

\begin{tabular}{cc}
\hline General & \\
Knowledge & Study \\
\hline
\end{tabular}

Missed nursing care, unfinished care, nursing task incompletion, and nursing care rationing are all similar concepts. They are omissions of nursing care.

Top 5 missed nursing care activities: (1) ambulation, (2) assessing effectiveness of medications, (3) turning, (4) mouth care, \& (5) patient teaching.

Top 3 reasons for missed nursing care: (1) labor resources, (2) material resources, \& (3) communication.
Al-Kandari et al. (2009); Kalisch, Landstrom, \& Hinshaw (2009); Lawless (2010); Rochefort et al. (2010); Shubert et al. (2008); Sochalski (2004).

Al-Kandari et al. (2009); Gravlin et al. (2010); Kalisch, Landstronm, \& Williams (2009).

Al-Kandari et al. (2009); Gravlin et al. (2010). Kalisch, Landstronm, \& Williams (2009).

\section{Hospital and Unit} Variation

Differences in types of missed care:

No difference is basic care items and missed nursing care.

Nursing interventions and missing plans of care differed.

Differences in Reasons for missed care:

No difference in labor resources

Difference in communication and material resources.

Renal units had more missed nursing care

Top 3 missed nursing care activities across hospitals: (1) ambulation, (2) assessing effectiveness of medications, \& (3) mouth care.

Top 3 reasons for missed nursing care across hospitals: (1) labor resources, (2) material resources, \& (3) communication.
Kalisch, Landstronm, \& Williams (2009).

Kalisch, Landstronm, \& Williams (2009).

Kalisch, Landstronm, \& Williams (2009).

Kalisch, Landstronm, \& Williams (2009).

Kalisch, Landstronm, \& Williams (2009).

Kalisch, Tschannen, Lee, \& Friese (2011).

Kalisch, Tschannen, Lee, \& Friese (2011). 
Table 4. Synthesis of key findings: Missed nursing care literature review (continued)

\begin{tabular}{ll}
\hline \multicolumn{1}{c}{$\begin{array}{c}\text { Nursing and Patient } \\
\text { Perceptions }\end{array}$} & Study \\
\hline $\begin{array}{l}\text { RNs report more missed care than NAs } \\
\text { Similar perceptions of commonly missed care } \\
\text { of RNs and NAs include: (1) medication } \\
\text { administration, (2) prn medication requests, (3) } \\
\text { patient assessments, (4) focused reassessments, } \\
\& \text { (5) teaching about discharge planning. }\end{array}$ & \\
$\begin{array}{l}\text { Labor resources most common reason reported (2009). } \\
\text { for missed care by both RNs and NAs. }\end{array}$ & Gravlin et al. (2010); Kalisch (2009). \\
$\begin{array}{l}\text { Patients could report many items of missed } \\
\text { nursing care, but were unable to report patient } \\
\text { assessment, surveillance, and IV site care. }\end{array}$ & Kalisch, McLaughlin, and Dabney (2012). \\
\hline \multicolumn{2}{c}{ Teamwork } \\
\hline
\end{tabular}

Poor communication

Incomplete or no patient report

Lack of trust

Lack of understanding of roles

Negative relationship between teamwork scores and missed nursing care

Leadership

Shared mental model

Team orientation
Kalisch (2009).

Kalisch (2009).

Kalisch (2009).

Kalisch (2009).

Kalisch \& Lee (2010)

Kalisch \& Lee (2010)

Kalisch \& Lee (2010)

Kalisch \& Lee (2010) 
Table 4. Synthesis of key findings: Missed nursing care literature review (continued)

\begin{tabular}{|c|c|}
\hline Job Satisfaction & Study \\
\hline $\begin{array}{l}\text { Missed nursing care is significant predictor of } \\
\text { intention to leave. }\end{array}$ & Tschannen, Kalisch, \& Lee (2010). \\
\hline $\begin{array}{l}\text { Nurses whom reported less missed care had } \\
\text { greater job satisfaction. }\end{array}$ & Kalisch, Tschannen, Lee, \& Salsgiver (2011). \\
\hline $\begin{array}{l}\text { Staffing adequacy and missed care are } \\
\text { significant predictors of job satisfaction }\end{array}$ & Kalisch, Tschannen, Lee, \& Salsgiver (2011). \\
\hline $\begin{array}{l}\text { More favorable work environments are related } \\
\text { to lower levels of care rationing. }\end{array}$ & Rochefort \& Clark (2010). \\
\hline Staffing Adequacy & Study \\
\hline $\begin{array}{l}\text { HPPD is a significant predictor of missed } \\
\text { nursing care. }\end{array}$ & Kalish, Tschannen, \& Lee (2011). \\
\hline $\begin{array}{l}\text { As the number of patients cared for increases } \\
\text { the amount of unfinished nursing care } \\
\text { increases. }\end{array}$ & Sochalski (2004). \\
\hline $\begin{array}{l}\text { When patient to nurse ratio was less than } 5: 1 \\
\text { there is less care rationing. }\end{array}$ & Al-Kandari \& Thomas (2009) \\
\hline Outcomes & Study \\
\hline $\begin{array}{l}\text { Missed care mediates the relationship between } \\
\text { HPPD and fall rate. }\end{array}$ & Kalisch, Tschannen, \& Lee (2012). \\
\hline $\begin{array}{l}\text { Nurse rationing is associated with the } \\
\text { following patient outcomes: (1) patient } \\
\text { satisfaction, (2) medication errors, ( } 3 \text { ) patient } \\
\text { falls, (4) nosocomial infections, (5) critical } \\
\text { incidents, and (6) pressure ulcers }\end{array}$ & Schubert et al. (2008). \\
\hline
\end{tabular}




\section{Chapter III}

\section{Methods}

\section{Study Design}

The specific aims of this study were accomplished with a descriptive design using adjusted correlations and comparisons. Descriptive designs are appropriate when a phenomenon of interest has not been thoroughly studied (Brink \& Wood, 1998). The descriptive design of this study is appropriate, as the relationship between the impacts of HIT on nursing practice have not been widely studied (Dykes et al., 2007; Goldzweig et al., 2009). Although this is a descriptive design, missed nursing care will serve as the outcome variable for data analysis. The primary independent variable for the study is the level of use of nursing care reminders. A mediating variable I-HIT will also be examined. Additionally, several control variables will be collected in order to adjust for extraneous variance. Please see Tables 1 and 2 for conceptual definitions and empirical indicators of all variables.

\section{Sample}

A convenience sample $(N=165)$ of medical and/or surgical, intensive care, and intermediate care registered nurses working on acute care hospital units was used in this study. The sample was obtained from one large Midwestern teaching hospital that agreed to participate in the study. All eligible nursing units $(N=19)$ were included in the study.

\section{Power analysis}

Multiple regression was conducted with 4 predictor variables, with a power of 0.80 , and a small effect size of 0.20 . Power analysis for multiple regression was evaluated with G*Power 3.1 
and indicates a minimum sample size of 33 for each model, but the plan was to collect data on 150 participants to ensure the detection of a small effect. (See Figure 2 for output).

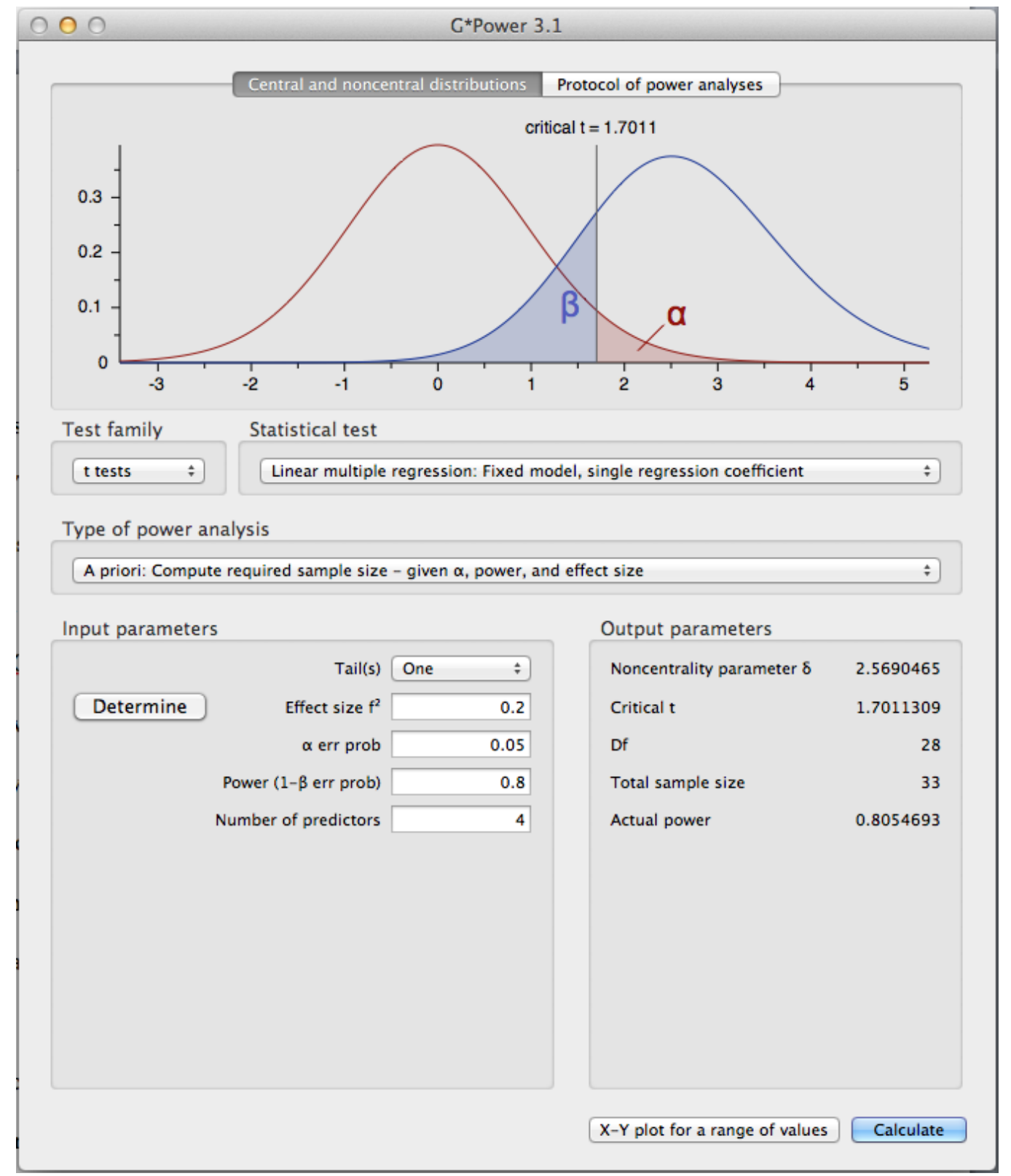

Figure 2. Power Analysis Output

\section{Inclusion/Exclusion Criteria}

Inclusion criteria for the study included that participants must be a staff registered nurse and take a daily patient assignment on the unit in which they work. The EHR must have been 
implemented for least six months, with nursing care reminders present in the EHR. Exclusion criteria for this study included unit employees that are non-registered nurse employees (e.g. LPN, PCA, clerks, etc.), registered nurses not assigned a patient assignment (e.g. managers, case managers, educators, nursing instructors, etc.), and student nurses.

\section{Instruments}

\section{MISSCARE Survey}

The Missed Nursing Care Survey (MISSCARE) is a two-part survey (See Appendix C) developed by Beatrice Kalisch in 2009. In the current study, only part A of the survey will be used. Part A of the survey contains 24-items that are designed to measure elements of missed nursing care (Kalisch \& Williams, 2009). Part A of the tool asks the participants to rate the frequency of missed nursing care on their unit, including themselves (Kalisch \& Williams, 2009). The rating is based on a five-point scale with anchors of "never" and "always". Part-B is used to measure the reasons for missed care and will not be used in this study. Content validity has been established through testing by three panels of staff nurses with a content validity index (CVI) of 0.89 (Kalisch \& Williams, 2009). Reliability for part A of the tool was established using test-retest reliability; the Pearson Product Moment Correlation Coefficient was 0.87 [ $p<$ 0.001; confidence interval, $0.76-0.93$ ] (Kalisch \& Williams, 2009).

The MISSCARE survey also contains a demographic questionnaire. This questionnaire will be used collect data regarding nurse characteristics. The demography questionnaire will be modified, as two characteristics of interest in the proposed study are not included in the survey. The two items are number of years as a registered nurse and amount of experience with current EHR. 


\section{Nursing Care Reminder Usage Survey}

A nursing care reminder usage survey was developed and used in this study (See Appendix E). The survey asked participants 12 questions regarding their usage and perceptions of nursing care reminders. The rating is based on a five-point scale with anchors of "never" and "always" with a N/A choice. Two specific questions of interest were the nurses self-reported level of use of nursing care reminders and the types of nursing care reminders they use.

The survey was pilot tested with two groups of practicing nurses. The first pilot contained 10 nurses from an information systems super-user group at a community hospital. The second pilot contained 17 nurses from a Magnet unit representative group at a large academic medical center. The participants in both pilots felt the survey had face validity. They stated the survey measured RN usage of nursing care reminders. The average time to complete the survey was 18.5 minutes in pilot 1 and 13.76 minutes in pilot 2. (See Tables $5 \& 6$ for a descriptive analysis of pilot one and two.)

In pilot 1, there was a range of responses for all questions except 1.2 (print-out of activities) and 1.6 (electronic list not in EHR). Both of these questions were included in pilot 2 for further evaluation. The majority of the questions had a mean between occasionally and frequently utilized. The range of the means for the questions was a Min of 1 to a Max of 4.1. Question 1.9 - Electronic checklist for documenting care that serve as a reminder, was removed as it was found to be redundant as this was already included in item 1.5.

In pilot 2, there was a range of responses for all questions. The majority of the questions had a mean between occasionally and frequently utilized. The range of the means for each of the items was a minimum of 1.93 and a maximum of 4.00. An additional item (1.10) was added to the survey as nurses indicated they received "Text page reminders". 
Table 5

Nursing Care Reminders Survey: Pilot one descriptive statistics

\begin{tabular}{lcccc}
\hline Variable & $M$ & $S D$ & Min & Max \\
\cline { 2 - 5 } NCRS 1.1 & 2.00 & 1.16 & 1 & 4 \\
NCRS 1.2 & 1.00 & 0.00 & 1 & 1 \\
NCRS 1.3 & 3.80 & 0.79 & 3 & 5 \\
NCRS 1.4 & 3.40 & 1.35 & 1 & 5 \\
NCRS 1.5 & 4.10 & 0.88 & 3 & 5 \\
NCRS 1.6 & 1.00 & 0.00 & $0^{*}$ & 1 \\
NCRS 1.7 & 3.11 & 1.17 & $0^{*}$ & 5 \\
NCRS 1.8 & 3.40 & 0.70 & 2 & 4 \\
NCRS 1.9 & 2.90 & 1.52 & 1 & 5 \\
NCRS 1.10 & 3.20 & 0.79 & 2 & 5 \\
NCRS 2 & 3.00 & 1.16 & 2 & 5 \\
NCRS 3 & 3.50 & 1.51 & 1 & 5 \\
\hline
\end{tabular}

Note: NCRS = Nursing Care Reminders Survey; $*$ not included in calculation of mean and standard deviation $(0=$ not applicable response $)$. 
Table 6

Nursing Care Reminders Survey: Pilot two descriptive statistics

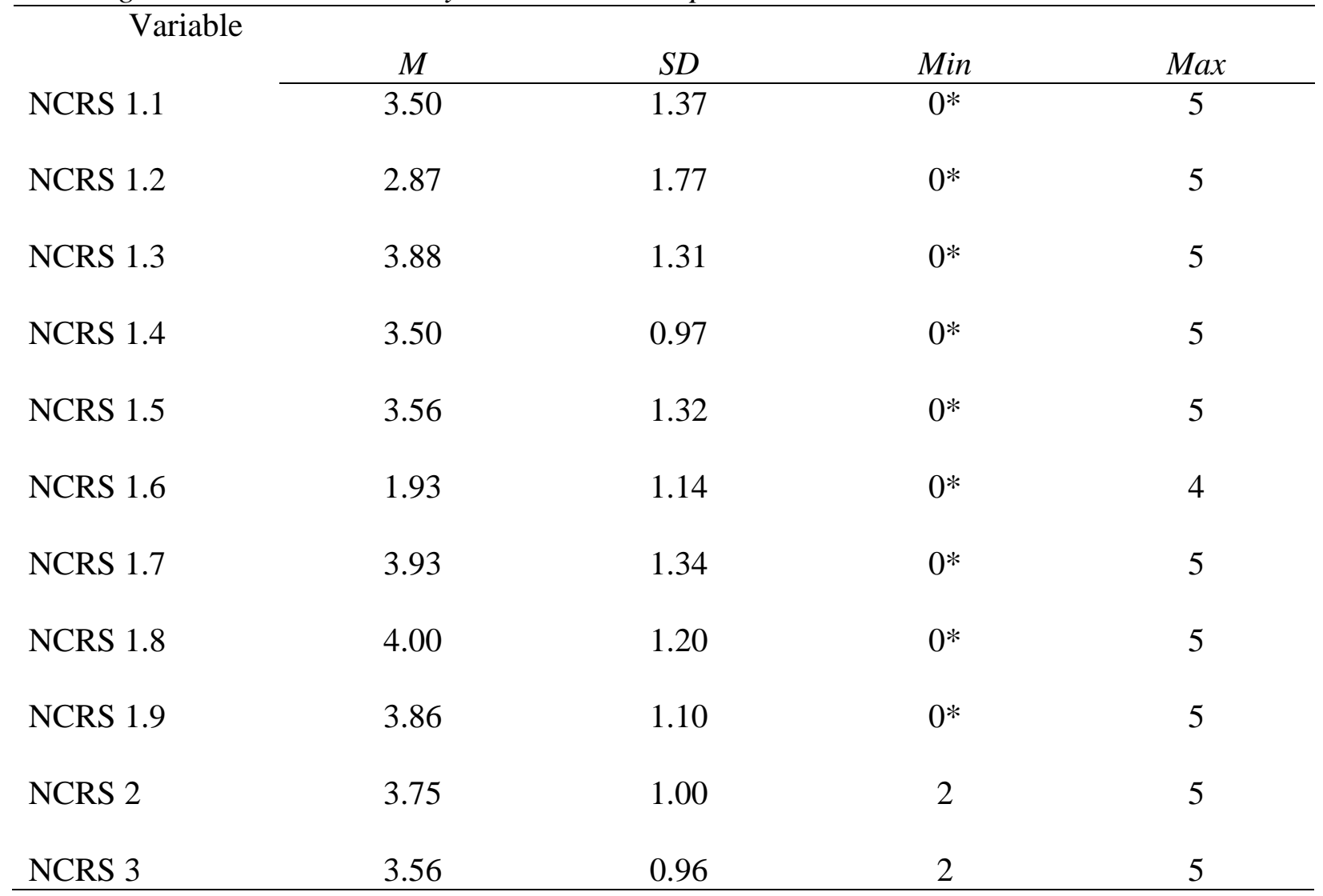

Note: NCRS = Nursing Care Reminders Survey; $*$ not included in calculation of mean and standard deviation $(0=$ not applicable response $)$. 


\section{I-HIT Scale}

The I-HIT scale was conceptualized and developed by Patricia Dykes and Charlotte Weaver in 2005 (See Appendix D for scale). The scale is composed of 29-items contained in four subscales (Dykes, et al., 2007). The first subscale is the general advantages of HIT and contains items that are related to HIT facilitating patient-centered communication by providing access to data and information within the context of acute care workflows. The second subscale is workflow implications of HIT subscale and contains items that are related to how HIT supports nurses' role as integrator and communicator. The third sub-scale is information tools to support communication tasks and contains items that are related to the availability and use of HIT tools that optimize and support the work of nurses. The last subscale is information tools to support information tasks and contains items related to the appropriate use of information tools to support efficient communication. (Dykes et al., 2007)

Content validity assessment by five nursing informatics content experts was performed. They utilized a two-point scale to rate each items relevance under the theme in which it was listed. This resulted in the 43-item scale with a content validity index (CVI) of 1.0. The 43-items achieved a content validity index beyond the 0.05 significance level. (Dykes et al., 2007)

Internal consistency reliability was determined using Cronbach's alpha for each of the 43 items on the initial scale. Those items with an inter-item correlation of less than 0.35 were removed $(n=11)$ and resulted in a 32 -item scale. The analysis was repeated and any additional items with an inter-item correlation less than 0.35 were removed. Two additional items were found to have an inter-item correlation of 0.8 , which indicates redundancy and were removed. This resulted in the final 29-item scale (Dykes et al., 2007). 
Principal components analysis (PCA) with Varimax rotation and Kaiser Normalization was used for factor analysis of the data. Eigen values exceeding one were found for five items that explained $62 \%$ of the variance, which was consistent with the theoretical prediction (Dykes et al., 2007). The five-component model was found to be parsimonious, but was not easily interpretable, so a four-component model was developed (Dykes et al., 2007). A scree plot was generated for the four-component model, the plot leveled off after the fourth factor, which indicated that appropriateness of the four-component model. The Varimax rotation revealed strong loadings for the four factors and significant side loadings of 17 items. These items were kept with the factor associated with the strongest loading and that was conceptually aligned with the statement. The four factors from the PCA explained 58.5\% of total variance (Dykes et al., 2007).

Internal consistency using Cronbach's alpha was 0.95 for the 29-item scale. Internal consistency of the four subscales ranged from 0.80 to 0.89 . The four subscales of the scale are:

1. General advantages of HIT (9 items) - $\alpha 0.88 ; 14 \%$ of variance

2. Workflow implication of HIT ( 8 items) - $\alpha 0.89 ; 16.1 \%$ of variance

3. Information tools to support communication tasks ( 7 items) - $\alpha 0.86 ; 12.6 \%$ of variance

4. Information tools to support information tasks (5 items) - $\alpha 0.80 ; 12.1 \%$ of variance (Dykes et al., 2007)

The authors examined concurrent validity by examining correlations between mean total subscale scores and the scores from the Overall Satisfaction Impact of Health Information Technology (OSI-HIT) scale (Dykes et al., 2007). The OSI-HIT scale was developed along with the I-HIT scale to measure overall satisfaction with HIT to measure concurrent validity (Dykes et 
al., 2007). The author's hypothesized that a high score on the OSI-HIT would be correlated to high scores on the I-HIT scale (Dykes et al., 2007). Moderate to large correlations were noted between the OSI-HIT scale and the four sub-scales of the I-HIT (Dykes et al., 2007). This was interpreted as providing support for criterion related validity.

The I-HIT scale is scored using a six-point Likert-type scale and a not applicable choice. The possible choices range from one to six (strongly disagree to strongly agree) and not applicable. The authors suggested that higher scores indicate greater nurse agreement with statements on the impact of HIT in the care they provide, their work at the bedside, and the impact on interdisciplinary communication (Dykes et al., 2007).

\section{Other Variables}

Additionally, staffing adequacy and acuity were collected. These variables were collected at the unit level. These two variables were collected using a standardized form developed by the principal investigator (PI). (See Appendix F for form).

\section{Procedure}

Institutional review board (IRB) approval was obtained from both the University of Michigan and the study hospital. The IRB application received an expedited review as no participant identifying information was being collected. There was minimal chance for harm to subjects as they completed an anonymous survey. The participants survey data was downloaded into SPSS for data analysis. The data was stored on a password-protected computer that is accessible only to the PI. The completed online surveys were deleted after the data was downloaded.

Implied consent from participants was obtained if the nurses completed the online surveys. An informational only consent form describing the study was included in the participant 
email and survey directions, but participants were not required to sign and return the form. The online survey included study instruments; consent information, and detailed directions. The surveys were administered as an online survey with a link sent to participants via email (See Appendix G for email).

The survey was administered using the Qualtrics survey software. The survey is anonymous, as no identifying information was collected. Email addresses were used to send the survey to each participant in the study. The survey was sent out to each unit separately so5 the PI could determine the response rate by unit. Email addresses were obtained with assistance from the hospital research sponsor. Email addresses were associated with the data collected. Respondent burden is expected to be minimal as the instruments and demographic survey are short and took less than 20 minutes in the pilot of the instruments.

Flyers were placed in high visibility areas to remind nurses to complete the survey (See Appendix I for email). A reminder email was sent to all nurses twice a week via email. All surveys were due at 4 weeks. Units that had a response rate greater than or equal to $60 \%$ received a unit incentive of a large Edible Arrangement for each shift. Unfortunately, no unit had a response rate of $60 \%$ or greater.

\section{Review of Research Questions}

\section{Relationships}

1. Controlling for CMI, RNHPPD, and nurse characteristics examine the following relationships:

a. Is there a relationship between nurses' level of use of reminders and missed nursing care?

b. Is there a relationship between I-HIT scores and missed nursing care? 


\section{Mediating Relationships}

2. Does I-HIT mediate the relationship between nursing care reminders and missed nursing care?

\section{Comparisons}

3. Controlling for CMI, RNHPPD, and nurse characteristics compare the following:

a. Do nurses who report higher levels of use of nursing care reminders have reports of decreased or less missed nursing care?

b. Do nurses who have more positive perceptions of I-HIT on their practice have reports of decreased or less missed nursing care?

\section{Data Analysis}

Data was analyzed using SPSS 21 . The data was cleaned and descriptive analysis was conducted to examine normality and linearity of variables. This was accomplished through interpretation of descriptive statistics and visual examination of graphs and plots. Assumptions for regression and multivariate analysis were also assessed (i.e., independence, normality, linearity, and multicollinearity).

Stepwise regression entry was used to determine nurse characteristics to include in the regression models. Analysis indicated that only gender was a significant predictor of missed nursing care. The remaining nurse characteristic variables (See Table 2 for characteristics) were not found to be significant predictors of missed nursing care, and thus, were excluded from the analysis. The data was then split into two groups by using the $50^{\text {th }}$ percentile for each of the following variables: I-HIT scores and level of use of reminders to allow for the analysis of comparisons. The transformed variables were named nursing care reminders (high/low) and IHIT (high/low). 
Hierarchical multiple regression analysis with control variables was used to determine adjusted relationships between the variables of interest, examine mediating relationships, and make comparisons among groups. Significance tests and beta coefficients were analyzed and interpreted to determine the study outcomes. Control variables were entered into the model first to control for the effect of these variables and then the primary independent variables were entered (Polit, 2010).

In order to test for mediation, the method described by Baron and Kenny (1986) was used. According to Baron and Kenny (1986), a variable is considered a mediator (See Figure 3) when three criteria are met: (a) variation in the independent variable accounts for significant variation in the mediator variable (path $a$ ), (b) variation in the mediator variable accounts for significant variation in the dependent variable (path $b$ ), and (c) when paths a and $\mathrm{b}$ are controlled there is significant reduction in the variance between the independent variable and dependent variable (path $c$ ). The method consists of using three regression equations: (1) the independent variable must affect the mediator in the first equation, (2) the independent variable must affect the dependent variable, and (3) the mediator must affect the dependent variable (Baron and Kenny, 1986). When these three criteria are met, the relationship between the independent variable and the dependent variable must be less in the third equation than in the second (Baron and Kenny, 1986).

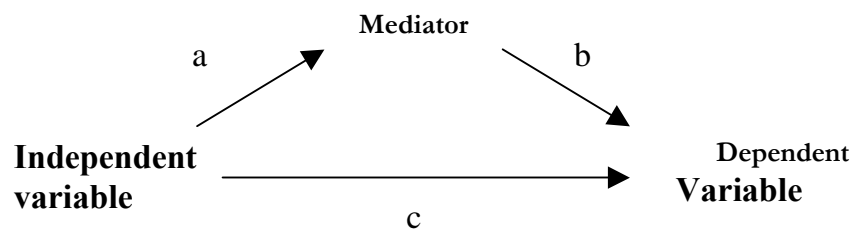

Figure 3. General mediation model 
Finally, the I-HIT scale and Nursing Care Reminders survey will be tested for reliability based on the participants of this study. This will be accomplished using Cronbach's alpha. The alpha value for all analyses is set at $p \leq 0.05$. 


\section{Chapter IV}

\section{Results}

\section{Demographics}

The sample $(N=165)$ consisted of staff nurses employed at a local hospital in the Midwestern United States during Fall 2012. The majority of the respondents held a Bachelor's Degree as their highest level of education $(n=114,69.1 \%)$, with $67.1 \%(n=110)$ of those participants having a Bachelor's of Science degree in Nursing (BSN). The majority of respondents were female $(n=145,87.9 \%)$ and between the ages of 25 and $34(n=61,37.0 \%)$. Over half of the participants in the study $(n=104,63.0 \%)$ worked on a medical surgical unit. See Table 7 for further descriptive analysis of demographic characteristics. 
Table 7

Demographic Characteristics of Sample

Age

Under 25 years old

25 to 34 years old

35 to 44 years old

45 to 54 years old

55 to 64 years old

Over 65 years old

\section{Characteristics}

$\frac{\text { Total sample }(N=165)}{n}$

23

3.9

$61 \quad 37.0$

$38 \quad 23.0$

$26 \quad 15.8$

$\begin{array}{ll}16 & 9.7\end{array}$

$1 \quad 0.6$

Gender

Male 20

12.1

$145 \quad 87.9$

Experience in role

Up to 6 months

Greater than 6 months to 2 years

$\begin{array}{rr}8 & 4.8 \\ 40 & 24.2\end{array}$

$35 \quad 21.2$

$23 \quad 13.9$

Greater than 5 years to 10 years

59

35.8

Experience as Registered Nurse (RN)

Up to 6 months

Greater than 6 months to 2 years

8

21.8
Greater than 2 years to 5 years

Greater than 5 years to 10 years

Greater than 10 years

21.2

15.2

37.0

61 3.0

27.3

47.3

15.2

7.3

Greater than 10 years

Highest Education Level

Associates degree

44

26.7

Bachelors degree

114

69.1

Graduate degree

7

4.2

Employment Status

Full-time

154

93.3

Part-time 


\section{Univariate Analysis}

Total missed nursing care scores ranged from a low of 24 to $\max$ of $84(M=56.09 ; S D=$ 11.79) out of a total possible score of 120 . Nursing care reminders total scores ranged from a low of 11 to max of $50(M=29.98 ; S D=8.11)$ out of a total possible score of 60 . Total I-HIT scores ranged from 28 to $171(M=129.32 ; S D=22.94)$ out of a total possible score of 174 . CMI ranged from a low of 4.87 to high of $18.24(M=9.09 ; S D=4.54)$. RNHPPD ranged from a low of 1.11 to a high of $6.99(M=2.25 ; S D=1.51)$.

\section{Unadjusted Correlations}

The relationship between missed nursing care (as measured by the MISSCARE Survey) and nursing care reminders (as measured by the Nursing Care Reminders Survey) was examined using Pearson product-moment correlation coefficient. There was a negative correlation between these two variables, $r=-.183, p<.05$, higher levels of reminder usage are associated with lower levels of missed nursing care.

The relationship between missed nursing care (as measured by the MISSCARE Survey) and the impact of health information technology (as measured by the IHIT Survey) was also investigated using Pearson product-moment correlation coefficient. A negative correlation was discovered between these two variables, $r=-.313, p<.01$, a positive outlook on the impact of information technology was associated with lower levels of missed nursing care.

The relationship between nursing care reminders (as measured by the Nursing Care Reminders Survey) and the impact of health information technology (as measured by the IHIT Survey) was examined using Pearson product-moment correlation coefficient. There was a positive correlation between the two variables, $r=.336, p<.01$, a positive view of information technology was associated with higher levels of reminder usage. 


\section{Adjusted Correlations}

Adjusted relationships using hierarchical multiple regression indicated significant negative relationships between missed nursing care and nursing care reminders and I-HIT. Preliminary analyses were conducted to ensure that there were no violation of the assumptions of normality, linearity, multicollinearity, and homoscedasticity. The first regression model was calculated to determine if there was a significant adjusted relationship between missed nursing care and nursing care reminders. CMI, RNHPPD, and gender were included as covariates in step one of the equation, and explained $8.3 \%$ of the variance in missed nursing care. After entry of nursing care reminders at step two, the total variance explained by the model as a whole was $15.2 \%, F(4,160)=7.15, p<.001$. Nursing care reminders explained an additional $7 \%$ of the variance in missed nursing care after controlling for CMI, RNHPPD, and gender, $R^{2}$ change $=$ $.07, F$ change $(1,160)=12.94, p<.001$. In the final model, only CMI (beta $=-.40, p=.001)$, gender $($ beta $=.16, p=.034)$, and nursing care reminders (beta $=-.28, p<.001)$ were statistically significant.

The second regression model was calculated to determine if there was a significant adjusted relationship between missed nursing care and I-HIT. CMI, RNHPPD, and gender were included as covariates in step one of the equation, and explained $8 \%$ of the variance in missed nursing care. After entry of I-HIT at step two, the total variance explained by the model as a whole was $18.8 \%, F$ change $(4,153)=8.85, p<.001$. I-HIT explained an additional $11 \%$ of the variance in missed nursing care after controlling for CMI, RNHPPD, and gender, $R^{2}$ change = $.11, F(1,153)=20.33, p<.001$. In the final model, only CMI (beta $=-.34, p=.003)$ and I-HIT (beta $=-.34, p<.001)$ were statistically significant. 


\section{Mediation}

The impact of Health Information Technology (IHIT) was hypothesized in this study as a mediating variable in the relationship between nursing care reminders (NCRS) and missed nursing care. To satisfy the requirements for mediation, 3 regression equations were computed. To establish mediation, the following conditions must be satisfied: (a) NCRS must affect IHIT; (b) NCRS must affect missed nursing care in the second equation; and (c) IHIT must affect missed nursing care in the third equation. When equations 1 and 3 are controlled, a previously significant relationship between the independent and dependent variables is no longer significant, indicating strong demonstration of mediation (Krause et al., 2010).

In equation 1 , IHIT, the mediator variable, was regressed on the predictor variable, NCRS. As noted in Figure 4, results indicated that NCRS was significantly associated with IHIT $\left(F_{156}=19.84, p<.001\right)$. NCRS explained $11.3 \%$ of the variance in IHIT scores.

In equation 2, missed nursing care, the outcome variable, was regressed on the predictor variable, NCRS. NCRS was significantly associated with missed nursing care $\left(F_{163}=5.67, p=\right.$ $.018)$. NCRS explained $3.4 \%$ of the variance in missed nursing care.

In the final equation, missed nursing care, the outcome variable, was regressed on the predictor variable, NCRS, and the mediator variable (IHIT). IHIT negatively affected missed nursing care $(t=-4.12, p<.001)$, explaining $9.8 \%$ of variance in missed nursing care. With IHIT present, the predictor (NCRS) was no longer significant $(t=-.70, p=.48)$. Thus, the reduced direct association between NCRS and missed nursing care when IHIT was in the model supported the hypothesis that IHIT was at least 1 of the mediators in the relationship between NCRS and missed nursing care. 


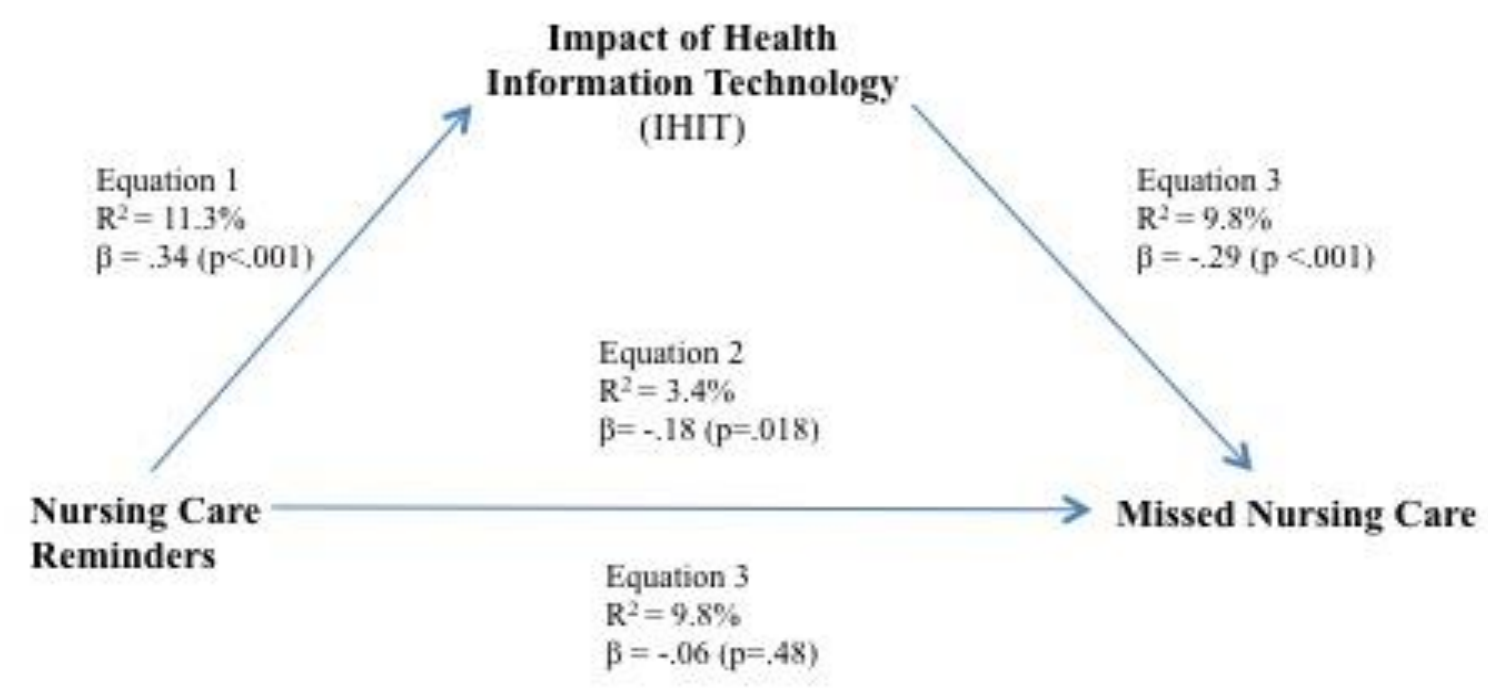

Figure 4. Test of the mediation model with regression analyses.

\section{Comparisons}

Adjusted relationships using hierarchical multiple regression using the two transformed variables of nursing care reminder usage (high/low) and I-HIT (high/low) indicated significant negative relationships between missed nursing care and nursing care reminders and I-HIT. Preliminary analyses were conducted to ensure that there were no violation of the assumptions of normality, linearity, multicollinearity, and homoscedasticity. The first regression model was calculated to determine if there was a significant adjusted relationship between missed nursing care and nursing care reminders (high/low). CMI, RNHPPD, and gender were included as covariates in step one of the equation, and explained $8.3 \%$ of the variance in missed nursing care. After entry of nursing care reminders at step two, the total variance explained by the model as a whole was $12.9 \%, F(4,160)=5.94, p<.001$. Nursing care reminders explained an additional $4.6 \%$ of the variance in missed nursing care after controlling for CMI, RNHPPD, and gender, $R^{2}$ change $=.046, F$ change $(1,160)=8.48, p=.004$. In the final model, only CMI (beta 
$=-.34, p=.004)$, gender $($ beta $=.15, p=.046)$, and nursing care reminders $($ beta $=-.22, p<.004)$ were statistically significant.

The second regression model was calculated to determine if there was a significant adjusted relationship between missed nursing care and I-HIT (high/low). CMI, RNHPPD, and gender were included as covariates in step one of the equation, and explained $8 \%$ of the variance in missed nursing care. After entry of I-HIT (high/low) at step two, the total variance explained by the model as a whole was $15 \%, F$ change $(4,153)=6.75, p<.001$. I-HIT explained an additional $7 \%$ of the variance in missed nursing care after controlling for CMI, RNHPPD, and gender, $R^{2}$ change $=.07, F(1,153)=20.33, p=.001$. In the final model, only CMI (beta $=-.26, p$ $=.023$ ) and I-HIT (beta $=-.27, p=.001)$ were statistically significant.

\section{Instrument Reliabilities and Validity}

Test-retest reliability of the MISSCARE Survey was not conducted in the current study. Reliability for part A of the MISSCARE Survey was established using test-retest reliability in a previous study; the Pearson Product Moment Correlation Coefficient was $0.87[p<0.001$; confidence interval, $0.76-0.93$ ] indicating more than adequate reliability (Kalisch \& Williams, 2009). Reliability of the Nurse Care Reminders Survey in the current study was calculated using Cronbach's Alpha. The Cronbach's Alpha in this study was 0.84 , indicating more than adequate reliability. Reliability of the I-HIT scale for the current study was calculated using Cronbach's Alpha. The Cronbach's Alpha in this study was 0.94 , indicating more than adequate reliability.

The MISSCARE Survey has established content validity (Kalisch \& Williams, 2009). Content validity of the MISSCARE survey was established through testing by three panels of staff nurses with a content validity index (CVI) of 0.89 (Kalisch \& Williams, 2009). Five nursing informatics content experts established the content validity of the I-HIT survey (Dykes et al., 
2007). The experts utilized a two-point scale to rate each items relevance under the theme in which it was listed. This resulted in the 43-item scale with a content validity index (CVI) of 1.0. The 43-items achieved a content validity index beyond the 0.05 significance level (Dykes et al., 2007). Face validity of the Nursing Care Reminders Survey was established in the current study using two pilot surveys. The survey was pilot tested with two groups of practicing nurses. The first pilot contained 10 nurses from an information systems super-user group at a community hospital. The second pilot contained 17 nurses from a Magnet unit representative group at a large academic medical center. The participants in both pilots felt the survey had face validity. They stated the survey measured RN usage of nursing care reminders. 


\section{Chapter V}

\section{Discussion}

\section{Unadjusted and Adjusted Correlations}

Unadjusted and adjusted correlations support the research questions that there is a relationship between nursing care reminder usage and missed nursing care, and that there is a relationship between I-HIT and missed nursing care. The relationships are negative indicating that nurses that rate higher levels of usage and I-HIT have decreased reports of missed nursing care. This makes sense as those whom have higher scores on the I-HIT have positive perceptions about the impact of technology on their practice.

This finding is significant as nursing care reminders may be an effective intervention to decrease missed nursing care. Although, missing one instance of care may not impact overall patient outcomes, the cumulative effects may have a negative impact on patient outcomes. The use of nursing care reminders to alert nurses to cumulatively missed care may be an intervention to significantly reduce the amount of missed nursing care. Additionally, nurses with higher I-HIT scores may be more apt to use nursing care reminders that may result in decreased missed care.

A limitation of nursing science is that the relationship between missed nursing care and nursing care reminders has not been previously studied. This study was the first to study these relationships. It was hypothesized by Dykes et al. (2007) that nurses whom scored higher on the I-HIT would be more likely to use the clinical information systems and have improved outcomes. This is consistent with the findings in this study. Nurses that use reminders have decreased amounts of missed nursing care. 
An alternate explanation for this finding may be that nurses whom are more likely to use the EHR may be more likely to complete their nursing care activities. This is compared to nurses that may be less accountable and neither use the EHR consistently or make sure they complete all nursing care activities needed for their patients. Additionally, this study was conducted in one hospital. The hospital culture may have an effect on the use of the EHR reminders. As a result of the culture the nurses in this study may be more likely to use the reminders due to organizational pressures and also may have decreased amounts of missed nursing care to begin with.

\section{Mediation}

Analysis of mediation again supports the research question that I-HIT mediates the relationship between reminder usage and missed nursing care. Nurses that use reminders more frequently and have higher perceptions about the impact of HIT on their practice have less missed nursing care than nurses that use reminders alone.

This is a significant finding as nurses that have more positive perceptions of the impact of HIT on their practice have less missed nursing care than nurses that just use reminders alone. This is important as healthcare organizations can utilize the I-HIT to assess whether or not their nurses have positive perceptions about the technology systems they are required to use. Organizations can then target specific system design or workflow changes to improve nurses' perceptions of the impact of HIT on their practice.

A limitation of nursing science is that the mediating relationship between missed nursing care, I-HIT, and nursing care reminders has not been previously studied. This investigation was the first to study this mediating relationship. Although, Dkyes et al. (2007) hypothesized that nurses that have positive perceptions of the impact of HIT on their practice would be more likely to use the technology. Dykes et al. (2007) hypothesis is supported by the findings from this 
study. Courtney et al. (2008) found that CDSS must be aligned with the nurse's workflow if they are to use the systems. Saleem et al. (2005) reported that one facilitator to using CDSS by nurses was to integrate the reminders into the nurses' workflow.

An alternate explanation for this finding is that nurses that use nursing care reminders already have more positive perceptions of the impacts of HIT on their practice. Nurses that utilize the system may be more accountable and therefore have decreased amounts of missed nursing care to begin with. Organizational or cultural factors may also have an impact on nurses' perceptions of HIT on their practice.

\section{Comparisons}

Comparisons of nurses that report higher levels of reminder usage also have decreased reports of missed nursing care. This was also the result for I-HIT. Nurses that reported higher positive impacts of HIT on their practice had decreased reports of missed nursing care.

This finding is important because nurses that have decreased amounts of missed nursing care may have better patient outcomes. The use of nursing care reminders may then have an overall effect in decreasing the amount of missed nursing. Missed nursing care or care omissions are much more common than errors of commission (AHRQ, 2011). Encouraging nurses to use nursing care reminders may thus result in a net decrease in care omissions and improved patient quality and safety.

A limitation of nursing science is that the relationship between missed nursing care and nursing care reminders has not been previously studied. This study was the first to examine these comparisons. Kalisch (2012) found that missed nursing care was a mediating factor in patient falls. Choi et al. (2011) reported that nurses consistently stated CDSS contributed to improved nursing outcomes. Thus, if nurses utilize reminders more often they may have less missed 
nursing care, which can have an impact on outcomes such as, patient falls. Reducing care omissions, which are considered much more common than errors of commission (AHRQ, 2011) may have an overall improvement in quality of care. Ernesater et al. (2009) reported that nurses found CDDS to be quality improving.

An alternate explanation is that nurses that utilize the system are already highly accountable and therefore may already have a decreased amount of missed nursing care. These nurses may have well developed delegation and teamwork skills that result in effective and efficient nursing care. These efficient teams may therefore have less missed care to begin with. The organization in which these nurses work may also have an impact. The organizational culture may direct nursing usage of the EHR, nursing care activity completion, and influence perceptions about the technology system on practice.

\section{Model Evaluation}

The conceptual model used in this study was evaluated to determine if the proposed relationships existed. There were significant adjusted relationships between reminder usage, IHIT, and Missed nursing Care. Also, significant relationships were found between CMI, RHPPD, and gender. Additionally, a mediating relationship was found between nursing care reminders, I-HIT, and missed nursing care. These findings supports the conceptual model that IHIT mediates the relationship between nursing care reminder usage and missed nursing care.

\section{Implications}

The findings from this study have many practical implications. First of all, I-HIT can be used to assess the impact of technology on nursing practice. This information can then be used to evaluate HIT to determine where changes may need to occur to be better aligned with clinician workflow. Workflow alignment is important, as it has been suggested the poor workflow 
alignment has resulted in unintended consequences of HIT (Aarts et al., 2007; Harrison et al., 2007). The unintended consequences can result in new errors that have not been previously encountered before the implementation of the HIT (Ash, 2007, Han et al., 2005; Koppel et al. 2005).

A second implication is that properly designed nursing care reminders may influence usage and thus decrease the amount of missed nursing care. Reminders that nurses find helpful may result in increased usage of the reminders. There must be a balance between the quality and quantity of nursing care reminders. Reminders that are redundant or not seen as important may be missed or ignored. Missed or ignored reminders may then result in an increase in missed nursing care. One suggestion is that future designers of reminders may need to look at the cumulative effects of missed nursing care rather than individual instances of missed care. Patients that are not ambulated once may not be at a disadvantage in their healing compared to a patient that has missed multiple instances of ambulation. This cumulative effect needs to be further investigated.

A third implication is that nurses' need to be taught and encouraged in the proper usage of nursing care reminders. Nursing care reminders are adjuncts to clinical reasoning and are not a replacement for it. Although a patient may have many reminders, they may still require additional nursing care that is at the discretion of the individual nurse. Nurses using reminders properly may result in decreased missed nursing care. This may be especially true with novice nurses that may need the reminders to serve as cues of what nursing activities are appropriate for a particular patient. Additionally, more seasoned nurses may find reminders useful in validating their clinical reasoning. The reminders may be helpful for seasoned nurses whom are encountering a patient with a unique or unfamiliar plan of care. This is consistent with findings 
from the study conducted by Dowding et al. (2009a) in which they found novice nurses used the system more frequently and more seasoned nurses used the CDSS when they encountered an unfamiliar or complex case.

Finally, it was found that I-HIT mediates the relationship between nursing care reminder usage and missed nursing care. This information is useful in that designers of HIT systems need to keep in mind that impacts of the technology will influence usage. Many times systems are not designed to match the workflow of nurses. Systems built with redundant or impertinent reminders may be ignored. System designers must study which reminders nurses find most useful and which reminders result in the best quality outcomes.

\section{Strengths \& Limitations}

\section{Limitations and Anticipated Problems}

Limitations of this study include threats to internal and external validity. A threat to internal validity is that the sample size was not extremely large. The investigator addressed this by determining sample size a priori using a small effect size and limiting analysis to no more than four IVs in regression analysis. Selection bias is also a possible threat to internal validity for this study, as a convenience sampling method was used. Therefore, the relationships that were examined in this study may be attributed to sample characteristics rather than the true relationship between the variables of interest. This threat has been addressed by determining sample size a priori as stated above and including nurse characteristics as covariates in the

analyses. Instrumentation may also be a threat to internal validity of this study. The PI has addressed this by selecting instruments that have proven validity and reliability and are specifically designed to be used with registered nurses. 
Threats to external validity are present because of the fact that the sample may not be representative of the population and therefore the results may not be generalizable beyond the sample. The PI has taken this into consideration and has addressed this by examining the possible relationship of the nursing care reminders and missed nursing care in more than one nursing unit.

An additional limitation is that two of the covariate variables are measured at the unit level. The primary level of measurement in this study is the registered nurse. Thus there may be nesting of data. This may violate the assumption of independence of linear regression. The risk is that a significant effect may not be detected. This was not the case in this study as a significant relationship between the primary IV and DV was established.

\section{Future Research}

This study was a first step in establishing a linkage between the uses of nursing care reminders and missed nursing care. This study must be repeated with a larger sample to determine if the relationship holds. Second, the study needs to be repeated in multiple hospitals. The study hospital may have been extremely adept at using reminders, but other hospitals may have a different experience. The present study was also only conducted with one EHR, examining the relationships in organizations with different EHRs is also recommended.

A concept analysis on what constitutes nursing care reminders is also needed. The extant literature is void on this concept. A concept analysis should be conducted to determine the types of nursing care reminders and determine empirical definitions in order to measure them. Reminders are not unique to nursing, so literature from other disciplines may also need to be investigated. This needs to be conducted to determine if there are similar or different concepts that are associated with reminders. 
Ultimately, the goal of nursing care reminder research is to develop investigator designed reminders as interventions. These interventions will be designed to target specific missed care items. This is a lofty goal and a long-term endeavor as the different types of reminders nurses' use needs to be clearly defined. Also, before this can occur, exploratory research needs to be conducted to determine which types of reminders are effective in decreasing the specific types of missed nursing care.

\section{Conclusion}

This study was a first step in determining if HIT has an impact on nursing care process. The study was successful in that a significant relationship was found between nursing care reminders usage and decreased amounts of missed nursing care. Additionally I-HIT was found to be a mediator of reminder usage and missed nursing care. These are significant findings that can be used to encourage nurses to use nursing care reminders, helpful for information system designers when designing nursing care reminder, and helpful to healthcare organizations in assessing the impact of technology on nursing practice. It is imperative that missed nursing care be decreased to improve patient and organization outcomes. Nursing care reminders may be a viable solution to reduce missed nursing care in a technology rich healthcare environment. 
APPENDICES 


\section{Appendix A}

Clinical Decision Support System Literature Review Matrix 
Clinical Decision Support System Literature Review Matrix

\begin{tabular}{|c|c|c|c|c|c|c|c|}
\hline Source & Setting & Sample & Design & Instruments & Key Findings & Strengths & Limitations \\
\hline $\begin{array}{l}\text { Alquraini; } \\
2007\end{array}$ & $\begin{array}{l}\text { Ministry of } \\
\text { Health } \\
\text { Hospitals in } \\
\text { Kuwait }\end{array}$ & $\begin{array}{l}\text { Random } \\
\text { sample of } \\
574 \text { nurses } \\
(92.3 \% \\
\text { response } \\
\text { rate) }\end{array}$ & Survey & $\begin{array}{l}\text { Questionnaire } \\
\text { to measure } \\
\text { characteristics } \\
\text { and attitudes of } \\
\text { nurses toward } \\
\text { computerized } \\
\text { healthcare } \\
\text { information } \\
\text { systems }\end{array}$ & $\begin{array}{l}\text { ANOVA revealed } \\
\text { statistically } \\
\text { significant differences } \\
\text { in attitudes in relation } \\
\text { to nationality, level of } \\
\text { education, pervious } \\
\text { experiences in } \\
\text { computer use, and } \\
\text { computer skills } \\
\text { (P<.05). Multiple } \\
\text { regression showed } \\
\text { that gender (females), } \\
\text { nationality (non- } \\
\text { Kuwaiti), higher } \\
\text { education levels, and } \\
\text { longer duration of } \\
\text { computer use were } \\
\text { statistically } \\
\text { significant predictors } \\
\text { of positive attitudes } \\
\text { toward computerized } \\
\text { health information } \\
\text { system (P<0.05) }\end{array}$ & $\begin{array}{l}\text { Large } \\
\text { random } \\
\text { sample }\end{array}$ & $\begin{array}{l}\text { Occurred in } \\
\text { one county } \\
\text { with } \\
\text { majority of } \\
\text { nurses from } \\
\text { another } \\
\text { country } \\
\text { (Philippines } \\
\text { ) }\end{array}$ \\
\hline $\begin{array}{l}\text { Campion; } \\
2011\end{array}$ & $\begin{array}{l}\text { Surgical and } \\
\text { trauma ICUs in } \\
\text { academic }\end{array}$ & $\begin{array}{l}49 \text { hours of } \\
\text { observation } \\
\text { and } 49 \\
\text { instances of }\end{array}$ & $\begin{array}{l}\text { Direct } \\
\text { observation } \\
\text { and } \\
\text { unstructured }\end{array}$ & None & $\begin{array}{l}\text { The authors noted } \\
\text { significant barriers to } \\
\text { use. These include: } \\
\text { lack of reminders, }\end{array}$ & & $\begin{array}{l}\text { Small } \\
\text { sample, } \\
\text { unstructured }\end{array}$ \\
\hline
\end{tabular}




\begin{tabular}{|c|c|c|c|c|c|c|}
\hline & medical center & \begin{tabular}{|l} 
RNs using \\
intensive \\
insulin \\
therapy; 16 \\
patients \\
observed; 25 \\
nurses \\
observed; 27 \\
nurses \\
interviewed
\end{tabular} & $\begin{array}{l}\text { interviews of } \\
\text { RNs }\end{array}$ & & $\begin{array}{l}\text { inaccurate user } \\
\text { interface design. } \\
\text { Similarly the authors } \\
\text { noted facilitators to } \\
\text { successful use. These } \\
\text { include: nurse trust in } \\
\text { the CDSS with } \\
\text { clinical judgment. }\end{array}$ & interviews. \\
\hline Cho, 2010 & $\begin{array}{l}\text { Two teaching } \\
\text { hospitals in } \\
\text { Seoul Korea }\end{array}$ & $\begin{array}{l}32 \mathrm{RNs}, \\
\text { only } 18 \\
\text { completed } \\
\text { study, } 56 \% \\
\text { participation } \\
\text { rate }\end{array}$ & $\begin{array}{l}\text { Repeated } \\
\text { measures } \\
\text { factorial } \\
\text { design (split- } \\
\text { plot design) } \\
\text { and feedback } \\
\text { from nurses }\end{array}$ & $\begin{array}{l}2 \text { written } \\
\text { scenarios }\end{array}$ & $\begin{array}{l}\text { User preferences for } \\
\text { display of information } \\
\text { in CDSS differed } \\
\text { significantly between } \\
\text { novice and expert } \\
\text { nurses. The novice } \\
\text { nurses wanted to see } \\
\text { all possible problems } \\
\text { for patients, whereas } \\
\text { expert nurses only } \\
\text { wanted the top five } \\
\text { problems. } \\
\text { The nurses stated that } \\
\text { the CDSS was well } \\
\text { organized and } \\
\text { facilitated patient } \\
\text { problem } \\
\text { identification. } \\
\text { The nurses also felt } \\
\text { that automatics } \\
\text { suggestions and data }\end{array}$ & $\begin{array}{l}\text { Small } \\
\text { sample, low } \\
\text { participation } \\
\text { by sample, } \\
\text { conducted } \\
\text { in foreign } \\
\text { country with } \\
\text { different } \\
\text { health } \\
\text { system than } \\
\text { USA }\end{array}$ \\
\hline
\end{tabular}




\begin{tabular}{|c|c|c|c|c|c|c|}
\hline & & & & & $\begin{array}{l}\text { driven approaches to } \\
\text { assessments were } \\
\text { desirable features of } \\
\text { the system. } \\
\text { The nurses felt that } \\
\text { the CDSS was tedious } \\
\text { and difficult to input } \\
\text { data and the display } \\
\text { for data input was too } \\
\text { complicated. }\end{array}$ & \\
\hline Choi; 2011 & $\begin{array}{l}\text { Six hospitals in } \\
\text { a single } \\
\text { university } \\
\text { medical system } \\
\text { in Korea }\end{array}$ & 37 nurses & $\begin{array}{l}\text { Qualitative } \\
\text { focus-groups }\end{array}$ & $\begin{array}{l}\text { Discussion } \\
\text { guidelines } \\
\text { developed for } \\
\text { focus groups }\end{array}$ & $\begin{array}{l}\text { The nurses } \\
\text { consistently stated } \\
\text { that CDSSs can } \\
\text { contribute to } \\
\text { improving nursing } \\
\text { outcomes by } \\
\text { standardizing nursing } \\
\text { care. } \\
\text { The nurses wanted a } \\
\text { system to remind } \\
\text { them of scheduled } \\
\text { care, assesses } \\
\text { deleterious changes in } \\
\text { patient condition, and } \\
\text { acuity level. } \\
\text { Nurse wanted a } \\
\text { system that allowed } \\
\text { customized guidelines } \\
\text { for patients. }\end{array}$ & $\begin{array}{l}\text { Small } \\
\text { sample, } \\
\text { conducted } \\
\text { in foreign } \\
\text { country with } \\
\text { different } \\
\text { health } \\
\text { system than } \\
\text { USA }\end{array}$ \\
\hline
\end{tabular}




\begin{tabular}{|c|c|c|}
\hline $\begin{array}{l}\text { Courtney; } \\
2008\end{array}$ & $\begin{array}{l}\text { Review of } \\
\text { literature on } \\
\text { CDSS }\end{array}$ & $\begin{array}{l}\text { Nursing CDSS have } \\
\text { been designed for } \\
\text { information } \\
\text { management rather } \\
\text { than knowledge } \\
\text { generation. } \\
\text { User participation in } \\
\text { the design and } \\
\text { implementation of the } \\
\text { system increase the } \\
\text { likelihood of } \\
\text { successful } \\
\text { implementation and } \\
\text { utilization of the } \\
\text { system. } \\
\text { CDSS must fit within } \\
\text { workflow of clinician. } \\
\text { They must feel that } \\
\text { CDSS address a } \\
\text { particular and } \\
\text { important concern for } \\
\text { clinical practice. } \\
\text { System integration } \\
\text { may be a factor in } \\
\text { user acceptance of } \\
\text { system. Redundant } \\
\text { data entry in disparate } \\
\text { system may decrease } \\
\text { user acceptance. }\end{array}$ \\
\hline
\end{tabular}




\begin{tabular}{|c|c|c|c|c|c|c|c|}
\hline $\begin{array}{l}\text { Dowding; } \\
\text { 2009a }\end{array}$ & $\begin{array}{l}\text { Secondary } \\
\text { analysis: } \\
\text { Telephone } \\
\text { triage center; } \\
\text { Case analysis: } \\
\text { primary care, } \\
\text { NHS walk-in } \\
\text { center, }\end{array}$ & $\begin{array}{l}\text { Secondary } \\
\text { analysis: } \\
53 \\
\text { qualitative } \\
\text { interviews of } \\
\text { nurses } \\
\text { working in } \\
\text { telephone } \\
\text { triage } \\
\text { system in } \\
\text { UK; } \\
\\
\text { Case } \\
\text { analysis: } \\
80 \\
\text { observations } \\
\text { of nurse- } \\
\text { patient } \\
\text { consultation } \\
\text { s and 11 } \\
\text { interviews } \\
\text { with nurses. }\end{array}$ & $\begin{array}{l}\text { Secondary } \\
\text { analysis: } \\
\text { Secondary } \\
\text { data analysis } \\
\text { of qualitative } \\
\text { interview } \\
\text { data. Data } \\
\text { analyzed } \\
\text { using } \\
\text { framework } \\
\text { analysis } \\
\\
\text { Case } \\
\text { analysis: two } \\
\text { case site } \\
\text { analyses. } \\
\text { Data } \\
\text { analyzed } \\
\text { using } \\
\text { thematic } \\
\text { content } \\
\text { analysis } \\
\end{array}$ & $\begin{array}{l}\text { Not indicated } \\
\text { but referred to } \\
\text { previous study } \\
\text { for additional } \\
\text { information }\end{array}$ & $\begin{array}{l}\text { Two main themes: } \\
\text { Nurse integration of } \\
\text { CDSS and effect of } \\
\text { nurses' experience on } \\
\text { how the CDSS was } \\
\text { used. } \\
\text { Integration: } \\
\text { Nurses had integrated } \\
\text { knowledge obtained } \\
\text { from previous CDSS } \\
\text { encounters to inform } \\
\text { their decisions or they } \\
\text { had learned the } \\
\text { underlying algorithms } \\
\text { of the CDSS. } \\
\text { Experience: } \\
\text { Nurses tended to use } \\
\text { the CDSS } \\
\text { recommendation } \\
\text { when they first started } \\
\text { and had little } \\
\text { experience in their } \\
\text { role. As the nurses } \\
\text { gained more } \\
\text { experience they were } \\
\text { less likely to follow } \\
\text { the guidance } \\
\text { contained within the } \\
\text { CDSS and use their } \\
\text { own professional }\end{array}$ & $\begin{array}{l}\text { Interviewe } \\
\mathrm{d} \text { and } \\
\text { observed } \\
\text { nurses in } \\
\text { practice } \\
\text { that } \\
\text { actually } \\
\text { were } \\
\text { using a } \\
\text { CDSS to } \\
\text { inform } \\
\text { their } \\
\text { practice. } \\
\text { Observed } \\
\text { nurses in a } \\
\text { variety of } \\
\text { settings. }\end{array}$ & $\begin{array}{l}\text { Small } \\
\text { sample size. } \\
\text { Evaluated } \\
\text { only the } \\
\text { outpatient } \\
\text { setting. } \\
\text { Conducted } \\
\text { in foreign } \\
\text { country with } \\
\text { different } \\
\text { health } \\
\text { system than } \\
\text { US. Did not } \\
\text { utilize } \\
\text { conceptual } \\
\text { framework } \\
\text { or model to } \\
\text { guide study. }\end{array}$ \\
\hline
\end{tabular}




\begin{tabular}{|c|c|c|c|c|c|}
\hline & & & & $\begin{array}{l}\text { judgment and } \\
\text { override } \\
\text { recommendations if } \\
\text { they felt it was } \\
\text { appropriate. } \\
\text { Experience nurses } \\
\text { still valued CDSS and } \\
\text { utilized it with } \\
\text { unfamiliar cases or as } \\
\text { a memory aid. Valued } \\
\text { as a "safety-net" }\end{array}$ & \\
\hline $\begin{array}{l}\text { Dowding; } \\
\text { 2009b }\end{array}$ & $\begin{array}{l}4 \text { NHS Trusts } \\
\text { in England }\end{array}$ & $\begin{array}{l}115 \\
\text { nurse/patient } \\
\text { consultation } \\
\text { s and } 55 \\
\text { interviews } \\
\text { with nurses }\end{array}$ & $\begin{array}{l}\text { Multiple case } \\
\text { site study } \\
\text { using non } \\
\text { participant } \\
\text { observation } \\
\text { of } \\
\text { nurse/patient } \\
\text { consultations }\end{array}$ & $\begin{array}{l}\text { CDSS systems used } \\
\text { in a variety of ways } \\
\text { by nurses: recording } \\
\text { information, } \\
\text { monitoring patient's } \\
\text { progress, and } \\
\text { confirming decisions } \\
\text { already made. Nurses' } \\
\text { experience with } \\
\text { decision and } \\
\text { technology affected } \\
\text { how they used a } \\
\text { decision support } \\
\text { system and whether } \\
\text { or not they over-rode } \\
\text { recommendations } \\
\text { made by the system. } \\
\text { The ability of nurses } \\
\text { to adapt the } \\
\text { technology also } \\
\text { affected use. If a }\end{array}$ & $\begin{array}{l}\text { Length of } \\
\text { time } \\
\text { between } \\
\text { data } \\
\text { collection } \\
\text { and } \\
\text { publication. } \\
2001 \text { - 2002 } \\
\text { data } \\
\text { collection } \\
\text { and } \\
\text { publication } \\
\text { 2009. There } \\
\text { may have } \\
\text { been } \\
\text { significant } \\
\text { changes } \\
\text { since that } \\
\text { time. }\end{array}$ \\
\hline
\end{tabular}




\begin{tabular}{|c|c|c|c|c|c|c|c|}
\hline & & & & & $\begin{array}{l}\text { nurse was not familiar } \\
\text { with a patient they } \\
\text { often utilized the } \\
\text { CDSS } \\
\text { recommendations. } \\
\text { Some nurses felt that } \\
\text { after repeated use of } \\
\text { the algorithms they } \\
\text { had learned them and } \\
\text { found them of little } \\
\text { value. Some nurses } \\
\text { discussed how they } \\
\text { tailored the } \\
\text { algorithms by } \\
\text { directing the patient to } \\
\text { answer questions in a } \\
\text { specific order or } \\
\text { answer. }\end{array}$ & & \\
\hline $\begin{array}{l}\text { Dykes, P.; } \\
2007\end{array}$ & Acute-care & $\begin{array}{l}\text { Lit review: } \\
\text { number of } \\
\text { articles } \\
\text { selected not } \\
\text { reported }\end{array}$ & $\begin{array}{l}\text { Instrument } \\
\text { development } \\
\text { and } \\
\text { psychometric } \\
\text { evaluation; } \\
\\
\underline{\text { Item }} \\
\text { development: } \\
\text { critical lit } \\
\text { review, } \\
\text { telephone } \\
\text { focus groups, } \\
\text { transcript }\end{array}$ & $\begin{array}{l}\text { Developed the } \\
\text { I-HIT scale as } \\
\text { part of study }\end{array}$ & $\begin{array}{l}\text { Instrument } \\
\text { development: five } \\
\text { themes emerged: } 1 . \\
\text { Interdisciplinary } \\
\text { communication; } 2 . \\
\text { Information access; } 3 \text {. } \\
\text { Practice effectiveness } \\
\text { and efficiency; } 4 . \\
\text { Interdisciplinary } \\
\text { relationships; } 5 . \\
\text { Workflow } \\
\text { implications of HIT; } \\
50 \text { survey items } \\
\text { abstracted from } \\
\text { qualitative analysis; }\end{array}$ & $\begin{array}{l}\text { Strengths: } \\
\text { Findings } \\
\text { consistent } \\
\text { with } \\
\text { conceptual } \\
\text { framewor } \\
\mathrm{k} ;\end{array}$ & $\begin{array}{l}\text { Limitations: } \\
\text { Self- } \\
\text { reported } \\
\text { survey; non- } \\
\text { probability } \\
\text { sample } \\
\text { method; } \\
\text { unable to } \\
\text { determine } \\
\text { response } \\
\text { rate; only } \\
48.5 \% \text { of } \\
\text { respondents } \\
\text { to } \\
\text { psychometri }\end{array}$ \\
\hline
\end{tabular}




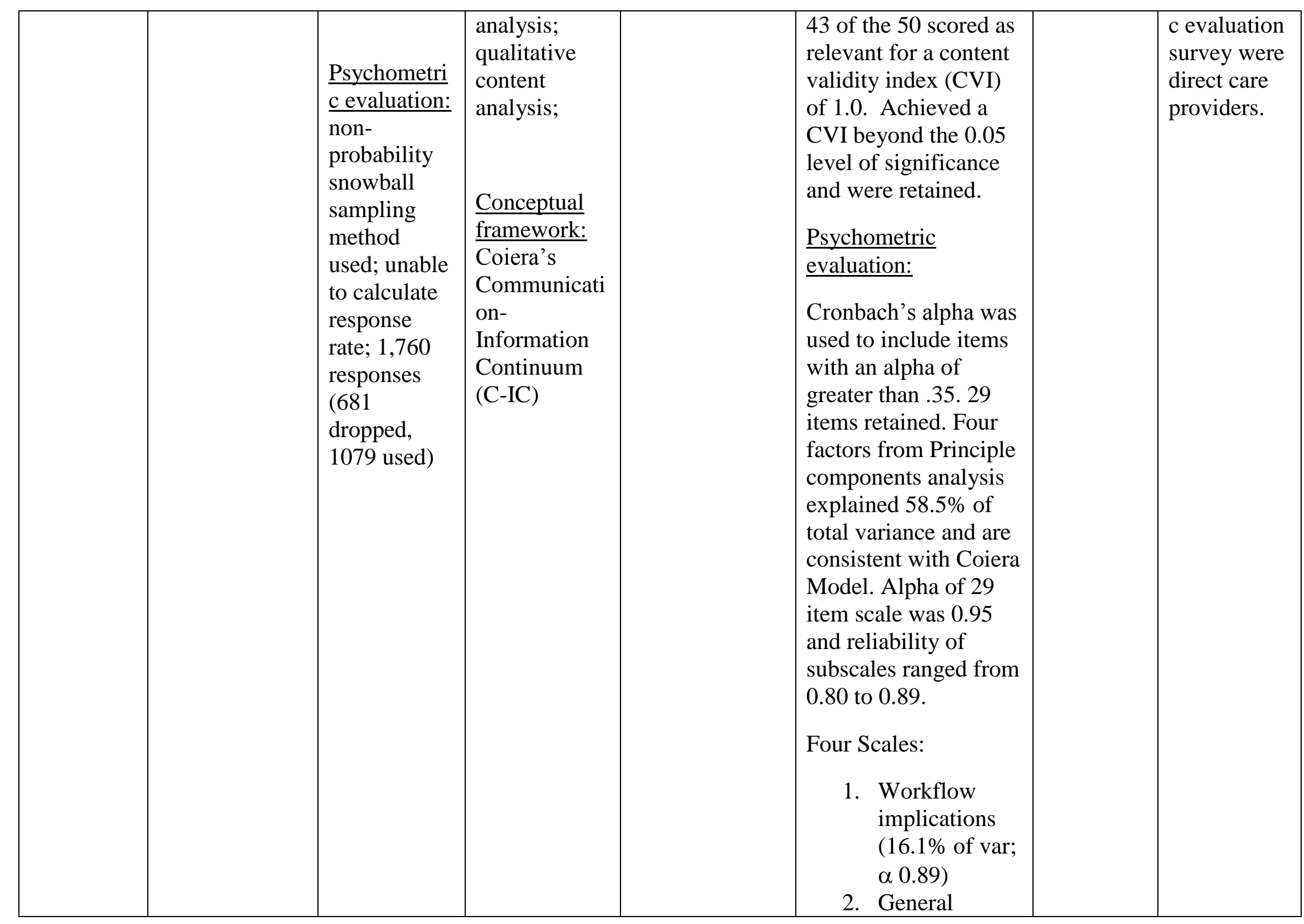




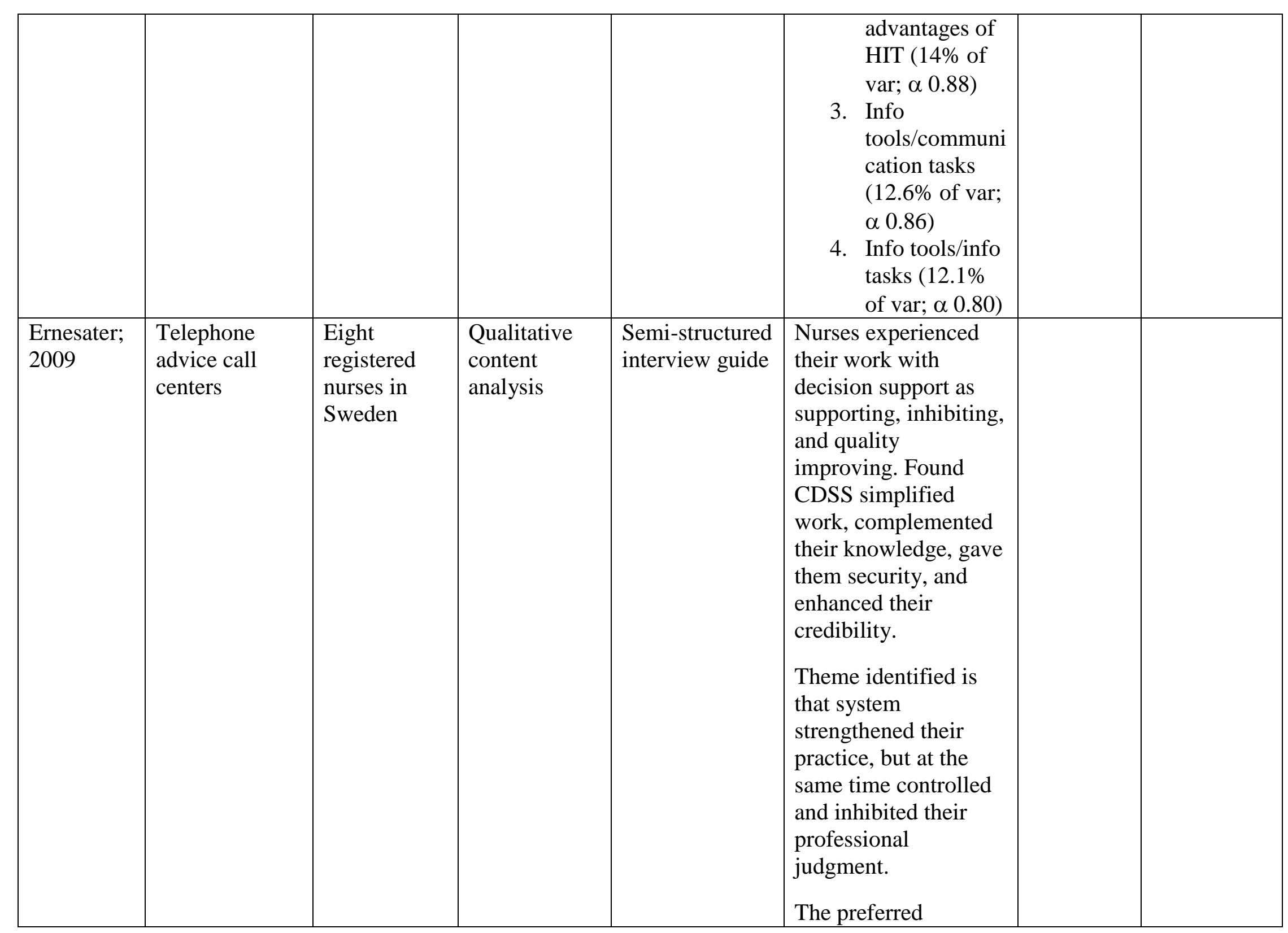




\begin{tabular}{|c|c|c|}
\hline & & $\begin{array}{l}\text { working with the } \\
\text { system. They } \\
\text { described that the } \\
\text { CDSS cannot replace } \\
\text { their knowledge and } \\
\text { competence and that } \\
\text { is should be } \\
\text { considered } \\
\text { complementary. } \\
\text { Reported that system } \\
\text { was incomplete, } \\
\text { sometimes in conflict } \\
\text { with their own } \\
\text { opinion, and } \\
\text { controlling. They felt } \\
\text { system ensured } \\
\text { quality of tele- } \\
\text { nursing. }\end{array}$ \\
\hline $\begin{array}{l}\text { Garg; } \\
2005\end{array}$ & $\begin{array}{l}\text { Systematic } \\
\text { review of } \\
\text { effects of } \\
\text { CDSS on } \\
\text { practitioner } \\
\text { performance } \\
\text { and patient } \\
\text { outcomes }\end{array}$ & $\begin{array}{l}\text { Reviewed } 100 \\
\text { studies. CDSS } \\
\text { improved practitioner } \\
\text { performance in } 62 \text { or } \\
64 \% \text { of studies. This } \\
\text { included studies on } \\
\text { diagnostic systems, } \\
\text { reminder systems, } \\
\text { disease management } \\
\text { system, drug-dosing } \\
\text { systems or prescribing } \\
\text { systems. } 52 \text { trials } \\
\text { assessed } 1 \text { or more } \\
\text { patient outcomes, of }\end{array}$ \\
\hline
\end{tabular}




\begin{tabular}{|c|c|c|}
\hline & & $\begin{array}{l}\text { which } 7 \text { or } 13 \% \\
\text { reported } \\
\text { improvements. } \\
\text { Improved } \\
\text { performance was } \\
\text { associated with CDSS } \\
\text { that automatically } \\
\text { prompted users vs } \\
\text { those that the user has } \\
\text { to initiate (success in } \\
73 \% \text { vs } 47 \% \text { ) and } \\
\text { studies in which } \\
\text { authors developed the } \\
\text { CDSS software } \\
\text { (success in } 74 \% \text { vs } \\
28 \% \text { ) }\end{array}$ \\
\hline $\begin{array}{l}\text { Hunt; } \\
1998\end{array}$ & $\begin{array}{l}\text { Systematic } \\
\text { review of } \\
\text { computer- } \\
\text { based clinical } \\
\text { decision } \\
\text { support } \\
\text { system on } \\
\text { physician } \\
\text { performance } \\
\text { and patient } \\
\text { outcomes }\end{array}$ & $\begin{array}{l}68 \text { controlled trials } \\
\text { reviewed. Effects on } \\
\text { performance were } \\
\text { assessed in } 65 \text { studies } \\
\text { and } 43 \text { found benefit } \\
(66 \%) \text {. This included } \\
\text { studies on drug } \\
\text { dosing systems, } \\
\text { diagnostic aids, } \\
\text { preventative care } \\
\text { systems, and CDSS } \\
\text { for other medical } \\
\text { care. Six of } 14 \\
\text { studies assessing } \\
\text { patient outcomes } \\
\text { found a benefit. Of } \\
\text { the remaining eight }\end{array}$ \\
\hline
\end{tabular}




\begin{tabular}{|c|c|c|c|c|}
\hline & & $\begin{array}{l}\text { only } 3 \text { had a power } \\
\text { greater than } 80 \% \text { to } \\
\text { detect for clinically } \\
\text { important effect. }\end{array}$ & & \\
\hline $\begin{array}{l}\text { Kawamoto } \\
\text {; } 2005\end{array}$ & $\begin{array}{l}\text { Systematic } \\
\text { review of } \\
\text { trials to } \\
\text { identify } \\
\text { features that } \\
\text { are critical to } \\
\text { CDSS } \\
\text { success }\end{array}$ & $\begin{array}{l}70 \text { studies included; } \\
\text { Decision support } \\
\text { systems significantly } \\
\text { improved clinical } \\
\text { practice in } 68 \% \text { of } \\
\text { trials. } \\
\text { Four system features } \\
\text { identified as } \\
\text { contributing to } \\
\text { clinical } \\
\text { improvements. These } \\
\text { include: automate } \\
\text { provision of decision } \\
\text { support as part of } \\
\text { clinician workflow, } \\
\text { provision of } \\
\text { recommendations } \\
\text { rather the just } \\
\text { assessments, } \\
\text { provision of decision } \\
\text { support at the time } \\
\text { and location of } \\
\text { decision making, and } \\
\text { computer based } \\
\text { decision support. Of } \\
\text { the } 32 \text { systems } \\
\text { possessing all four } \\
\text { features, } 30 \text { (94\%) }\end{array}$ & $\begin{array}{l}\text { Searched } \\
\text { more than } \\
10,000 \\
\text { articles } \\
\text { (thorough) } \\
\text {, reviewed } \\
\text { literature } \\
\text { for } \\
\text { relevant } \\
\text { expert } \\
\text { opinion on } \\
\text { system } \\
\text { features } \\
\text { that } \\
\text { determine } \\
\text { success, } \\
\text { used two } \\
\text { independe } \\
\text { nt } \\
\text { reviewers } \\
\text { for study } \\
\text { selection } \\
\text { and data } \\
\text { abstractio } \\
\text { n. }\end{array}$ & $\begin{array}{l}\text { Used binary } \\
\text { outcome } \\
\text { measure } \\
\text { rather than a } \\
\text { continuous } \\
\text { measure, } \\
\text { could not } \\
\text { adjust for } \\
\text { variations in } \\
\text { size of } \\
\text { outcomes, } \\
\text { pooled } \\
\text { different } \\
\text { types of } \\
\text { CDSS in } \\
\text { regression } \\
\text { analysis. }\end{array}$ \\
\hline
\end{tabular}




\begin{tabular}{|c|c|c|c|c|c|c|c|}
\hline & & & & & $\begin{array}{l}\text { improved clinical } \\
\text { practice. }\end{array}$ & & \\
\hline $\begin{array}{l}\text { Marshall; } \\
2011\end{array}$ & $\begin{array}{l}13 \text { bed ICU in } \\
\text { teaching } \\
\text { hospital in } \\
\text { Australia }\end{array}$ & $\begin{array}{l}6 \text { to } 17 \mathrm{RNs} \\
\text { depending } \\
\text { on stage of } \\
\text { data } \\
\text { collection }\end{array}$ & $\begin{array}{l}\text { Instrumental } \\
\text { case design } \\
\text { using } \\
\text { concurrent } \\
\text { verbal } \\
\text { protocols, Q } \\
\text { methodology } \\
\text { and focus } \\
\text { groups }\end{array}$ & $\begin{array}{l}\text { Q methodology } \\
\text { sort distribution }\end{array}$ & $\begin{array}{l}\text { Nurse preferred } \\
\text { information sources } \\
\text { are from other nurses } \\
\text { and colleagues. } \\
\text { Electronic resources } \\
\text { were not utilized as } \\
\text { much because they } \\
\text { were perceived as less } \\
\text { accessible and too } \\
\text { much time to access } \\
\text { information. }\end{array}$ & & $\begin{array}{l}\text { Varried } \\
\text { sample size, } \\
\text { only in one } \\
\text { hospital in } \\
\text { foreign } \\
\text { country with } \\
\text { different } \\
\text { health } \\
\text { system than } \\
\text { USA. }\end{array}$ \\
\hline $\begin{array}{l}\text { O'Cathain; } \\
2007\end{array}$ & $\begin{array}{l}\text { NHS } 24 \text { triage } \\
\text { center in } \\
\text { Scotland }\end{array}$ & 542 nurses & Descriptive & $\begin{array}{l}\text { Questionnaire } \\
\text { to measure } \\
\text { attitudes toward } \\
\text { risk }\end{array}$ & $\begin{array}{l}\text { Attitudes toward risk } \\
\text { varied greatly among } \\
\text { nurses. } 27 \% \text { agreed } \\
\text { that nurses should not } \\
\text { take risk with a } \\
\text { physical illness where } \\
17 \% \text { disagreed. After } \\
\text { case-mix adjustment } \\
\text { there was some } \\
\text { evidence that nurses' } \\
\text { attitudes towards risk } \\
\text { affected decisions but } \\
\text { this was inconsistent } \\
\text { and unconvincing. } \\
\text { Much of the decision- } \\
\text { making remained } \\
\text { unexplained. }\end{array}$ & $\begin{array}{l}\text { Provides } \\
\text { evidence } \\
\text { that there } \\
\text { is } \\
\text { variation } \\
\text { among } \\
\text { nurses } \\
\text { making } \\
\text { decisions } \\
\text { with } \\
\text { CDSS }\end{array}$ & $\begin{array}{l}\text { Instrument } \\
\text { did not } \\
\text { perform } \\
\text { well under } \\
\text { psychometri } \\
\text { c } \\
\text { evaluation. }\end{array}$ \\
\hline
\end{tabular}




\begin{tabular}{|c|c|c|c|c|c|c|}
\hline $\begin{array}{l}\text { O’Neill; } \\
2006\end{array}$ & Not identified & $\begin{array}{l}9 \text { nurses } \\
\text { from a local } \\
\text { healthcare } \\
\text { system and } 3 \\
\text { senior-leve } \\
\text { nursing } \\
\text { students } \\
\text { from local } \\
\text { baccalaureat } \\
\text { e nursing } \\
\text { program. }\end{array}$ & $\begin{array}{l}\text { Focus-group } \\
\text { and thematic } \\
\text { analysis }\end{array}$ & $\begin{array}{l}\text { Scenario } \\
\text { development } \\
\text { and } 4 \text { high- } \\
\text { level questions } \\
\text { designed to } \\
\text { promote critical } \\
\text { thinking }\end{array}$ & $\begin{array}{l}\text { Several nurses } \\
\text { expressed the need to } \\
\text { "trust" the } \\
\text { information. "Where } \\
\text { does this information } \\
\text { come from?" This } \\
\text { points to need to } \\
\text { make evidence-based } \\
\text { process to build } \\
\text { practice maps } \\
\text { transparent to users. } \\
\text { Clinician must be able } \\
\text { to trust the system to } \\
\text { provide accurate and } \\
\text { up to date } \\
\text { information. This was } \\
\text { also apparent in } \\
\text { nurses need for actual } \\
\text { data rather than an } \\
\text { interpretation of data. }\end{array}$ & $\begin{array}{l}\text { Nurses } \\
\text { could not } \\
\text { examine all } \\
\text { system data } \\
\text { and may } \\
\text { have felt } \\
\text { constrained } \\
\text { by limited } \\
\text { data }\end{array}$ \\
\hline $\begin{array}{l}\text { Piscotty; } \\
2011\end{array}$ & $\begin{array}{l}6 \text { hospitals } \\
\text { owned and/or } \\
\text { operated by a } \\
\text { national faith- } \\
\text { based } \\
\text { healthcare } \\
\text { organization }\end{array}$ & $\begin{array}{l}6 \text { Top- } \\
\text { nursing } \\
\text { leaders }\end{array}$ & $\begin{array}{l}\text { Qualitative } \\
\text { descriptive } \\
\text { thematic } \\
\text { analysis } \\
\text { using } \\
\text { grounded } \\
\text { theory }\end{array}$ & $\begin{array}{l}\text { Semi-structure } \\
\text { interview guide }\end{array}$ & $\begin{array}{l}\text { In regard to CIS } \\
\text { readiness, the } \\
\text { majority of CNE } \\
\text { responses were } \\
\text { classified into the } \\
\text { model thematic areas } \\
\text { of: champion support, } \\
\text { staff preparation for } \\
\text { change, training, } \\
\text { organizational } \\
\text { alignment, and } \\
\text { planning with the }\end{array}$ & $\begin{array}{l}\text { Small } \\
\text { sample, } \\
\text { respondents } \\
\text { all from } \\
\text { same parent } \\
\text { organization }\end{array}$ \\
\hline
\end{tabular}




\begin{tabular}{|c|c|c|}
\hline & & $\begin{array}{l}\text { themes of culture, } \\
\text { funding, access, } \\
\text { usability, decision- } \\
\text { making, and } \\
\text { communication } \\
\text { having the fewest } \\
\text { responses. A new } \\
\text { theme not previously } \\
\text { identified in the } \\
\text { model but clear in the } \\
\text { TNL responses is the } \\
\text { lack of vendor } \\
\text { support. }\end{array}$ \\
\hline $\begin{array}{l}\text { Powell- } \\
\text { Cope; } \\
2008\end{array}$ & $\begin{array}{l}\text { Integrated } \\
\text { literature } \\
\text { review on } \\
\text { patient care } \\
\text { technology }\end{array}$ & $\begin{array}{l}\text { Factors that influence } \\
\text { the use of technology: } \\
\text { Organizational } \\
\text { factors: policies, } \\
\text { resources, culture, } \\
\text { social norms, } \\
\text { management } \\
\text { commitment, training } \\
\text { programs, and } \\
\text { employee } \\
\text { empowerment } \\
\text { Characteristics of } \\
\text { nurses: age, } \\
\text { experience, mindset } \\
\text { about } \\
\text { technology/attitudes, } \\
\text { self-efficacy, } \\
\text { attention, fatigue, }\end{array}$ \\
\hline
\end{tabular}




\begin{tabular}{|c|c|c|c|c|c|c|}
\hline & & & & & $\begin{array}{l}\text { sensory inputs, } \\
\text { perception, goals, } \\
\text { intention to use, } \\
\text { knowledge } \\
\text { Physical environment: } \\
\text { lighting, noise, } \\
\text { architectural features } \\
\text { Technology } \\
\text { characteristics: } \\
\text { reliability, validity, } \\
\text { ergonomic design, } \\
\text { output display, input } \\
\text { mechanism, interface, } \\
\text { compatibility with } \\
\text { other technologies }\end{array}$ & \\
\hline $\begin{array}{l}\text { Randell; } \\
2010\end{array}$ & $\begin{array}{l}\text { Four site: } \\
\text { Anticoagulatio } \\
\text { n management } \\
\text { clinic, spinal } \\
\text { assessment } \\
\text { clinic, walk-in } \\
\text { center, and } \\
\text { respiratory } \\
\text { center }\end{array}$ & 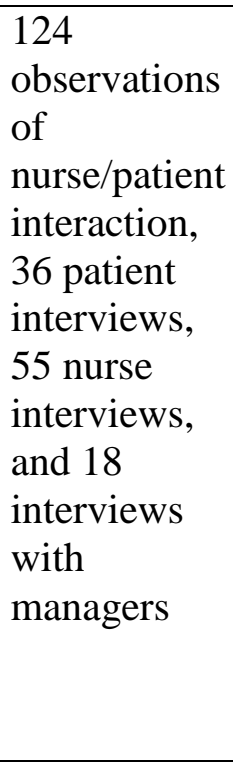 & $\begin{array}{l}\text { Multiple case } \\
\text { study design }\end{array}$ & $\begin{array}{l}\text { Observation } \\
\text { protocol, semi- } \\
\text { structured } \\
\text { questionnaire }\end{array}$ & $\begin{array}{l}\text { Key themes that } \\
\text { emerged from the } \\
\text { analysis indicated that } \\
\text { in order for a system } \\
\text { to be successful } \\
\text { clinician engagement } \\
\text { is necessary. } \\
\text { Additional themes } \\
\text { identified include: } \\
\text { adequate resources, } \\
\text { characteristics of the } \\
\text { system, and adequate } \\
\text { training. } \\
\text { Additionally the } \\
\text { nurses reported that a }\end{array}$ & $\begin{array}{l}\text { Case study } \\
\text { design in } \\
\text { only } 4 \\
\text { clinics. } \\
\text { Conducted } \\
\text { in foreign } \\
\text { country with } \\
\text { different } \\
\text { health } \\
\text { system then } \\
\text { USA. }\end{array}$ \\
\hline
\end{tabular}




\begin{tabular}{|c|c|c|c|c|c|}
\hline & & & & $\begin{array}{l}\text { supportive } \\
\text { environment and } \\
\text { desire to improve } \\
\text { quality are keys to } \\
\text { successful } \\
\text { implementation }\end{array}$ & \\
\hline $\begin{array}{l}\text { Randell; } \\
2009\end{array}$ & Primary care & $\begin{array}{l}76 \text { primary } \\
\text { care nurses } \\
\text { and } \\
\text { observations } \\
\text { of } 410 \\
\text { consultation } \\
\text { s carried out } \\
\text { by } 70 \\
\text { primary care } \\
\text { nurses }\end{array}$ & $\begin{array}{l}\text { Supplementar } \\
\text { y secondary } \\
\text { data analysis }\end{array}$ & $\begin{array}{l}\text { Many of the nurses } \\
\text { felt there was a need } \\
\text { for decision tools to } \\
\text { ensure consistently in } \\
\text { practice. Nurses stated } \\
\text { that they always } \\
\text { followed the } \\
\text { guidelines and they } \\
\text { had memorized them } \\
\text { and as such stated } \\
\text { they were working off } \\
\text { them even when not } \\
\text { looking at them. } \\
\text { Working with the } \\
\text { guidelines occurred } \\
\text { less frequently and } \\
\text { were often utilized in } \\
\text { unfamiliar cases. } \\
\text { Guidelines would } \\
\text { sometimes be checked } \\
\text { after the event to } \\
\text { ensure that they had } \\
\text { taken the correct } \\
\text { action. The nurses } \\
\text { stated that they had } \\
\text { helped develop the } \\
\text { guidelines and the }\end{array}$ & $\begin{array}{l}\text { Length of } \\
\text { time } \\
\text { between } \\
\text { data } \\
\text { collection } \\
\text { and } \\
\text { publication. } \\
2001 \text { - } 2002 \\
\text { data } \\
\text { collection } \\
\text { and } \\
\text { publication } \\
\text { 2009. There } \\
\text { may have } \\
\text { been } \\
\text { significant } \\
\text { changes } \\
\text { since that } \\
\text { time. }\end{array}$ \\
\hline
\end{tabular}




\begin{tabular}{|c|c|c|c|c|c|}
\hline & & & & & $\begin{array}{l}\text { wanted national } \\
\text { guidelines to be more } \\
\text { user-friendly and to } \\
\text { be able to adapt them } \\
\text { to meet their needs. }\end{array}$ \\
\hline $\begin{array}{l}\text { Randell; } \\
2007\end{array}$ & $\begin{array}{l}\text { ICU, } \\
\text { ambulatory } \\
\text { clinic, } \\
\text { telephone } \\
\text { triage }\end{array}$ & $\begin{array}{l}\text { Systematic } \\
\text { review: } 100 \\
\text { nurses and } \\
24,000 \\
\text { patients, } \\
7761 \text { articles } \\
\text { identified } \\
\text { through lit } \\
\text { search. } \\
\text { Excluded } \\
7418, \\
\text { reviewed } \\
\text { remaining } \\
343+49 \\
\text { identified } \\
\text { through } \\
\text { hand } \\
\text { searching } \\
\text { and expert } \\
\text { contacts. } \\
383 \\
\text { excluded, } 9 \\
\text { included in } \\
\text { review, } 8\end{array}$ & $\begin{array}{l}\text { Systematic } \\
\text { review }\end{array}$ & $\begin{array}{l}\text { Utilized } \\
\text { Cochrane } \\
\text { Effective } \\
\text { Practice and } \\
\text { Organization of } \\
\text { Care Group } \\
\text { data collection } \\
\text { checklist for } \\
\text { validity } \\
\text { assessment }\end{array}$ & $\begin{array}{l}\text { Nurses using CDSS } \\
\text { compared to those } \\
\text { that did not: } \\
\text { Three studies, one } \\
\text { study showed } \\
\text { improved } \\
\text { performance while } \\
\text { another it showed } \\
\text { poorer performance, } \\
\text { no study found an } \\
\text { impact of CDSS on } \\
\text { patient outcomes. } \\
\text { Nurses using CDSS } \\
\text { compared with other } \\
\text { health professionals: } \\
\text { In the five studies, } \\
\text { three RCTs found no } \\
\text { significant difference } \\
\text { in patient outcomes } \\
\text { with anticoagulation } \\
\text { management between } \\
\text { nurses and physicians. } \\
\text { CDSS was found to } \\
\text { be effective in two } \\
\text { studies that looked at }\end{array}$ \\
\hline
\end{tabular}




\begin{tabular}{|c|c|c|c|c|c|c|c|}
\hline & & & & & $\begin{array}{l}\text { triage and improved } \\
\text { performance as it } \\
\text { reduced GP workload } \\
\text { when nurses used } \\
\text { CDSS. One study } \\
\text { suggests that CDSS is } \\
\text { detrimental to patient } \\
\text { outcomes, while } \\
\text { another suggests it is } \\
\text { beneficial to some } \\
\text { outcomes. } \\
\text { Benefits of CDSS are } \\
\text { inconclusive and need } \\
\text { further investigation. }\end{array}$ & & \\
\hline $\begin{array}{l}\text { Saleem; } \\
2007\end{array}$ & Simulation; lab & $\begin{array}{l}16 \text { intake } \\
\text { nurses in } \\
\text { outpatient } \\
\text { clinic setting }\end{array}$ & $\begin{array}{l}\text { Simulation } \\
\text { experiment to } \\
\text { examine } \\
\text { impact of } 4 \\
\text { design } \\
\text { modifications } \\
\text { to CR } \\
\text { software: } \\
\text { learn ability, } \\
\text { usability, } \\
\text { efficiency, } \\
\text { and workload }\end{array}$ & $\begin{array}{l}\text { survey, and } \\
\text { semi-structure } \\
\text { debriefing } \\
\text { interview guide }\end{array}$ & $\begin{array}{l}\text { Redesign of clinical } \\
\text { reminders increase } \\
\text { learn ability for first- } \\
\text { time users as } \\
\text { measured by time to } \\
\text { complete first CR, } \\
\text { completion time for } \\
\text { two of five patient } \\
\text { scenarios, usability of } \\
\text { three groups of } \\
\text { questions from survey } \\
\text { instrument, and two } \\
\text { of six workload } \\
\text { subscales of the } \\
\text { NASA Task Load } \\
\text { Index (TLX) survey: } \\
\text { Mental workload and }\end{array}$ & $\begin{array}{l}\text { Utilized } \\
\text { multiple } \\
\text { measures }\end{array}$ & $\begin{array}{l}\text { Low sample } \\
\text { size, only } \\
\text { test one CR } \\
\text { system, } \\
\text { participants } \\
\text { first-time } \\
\text { users of } \\
\text { system, one } \\
\text { of authors } \\
\text { played role } \\
\text { of patient in } \\
\text { simulation } \\
\text { and may } \\
\text { have } \\
\text { influenced } \\
\text { results }\end{array}$ \\
\hline
\end{tabular}




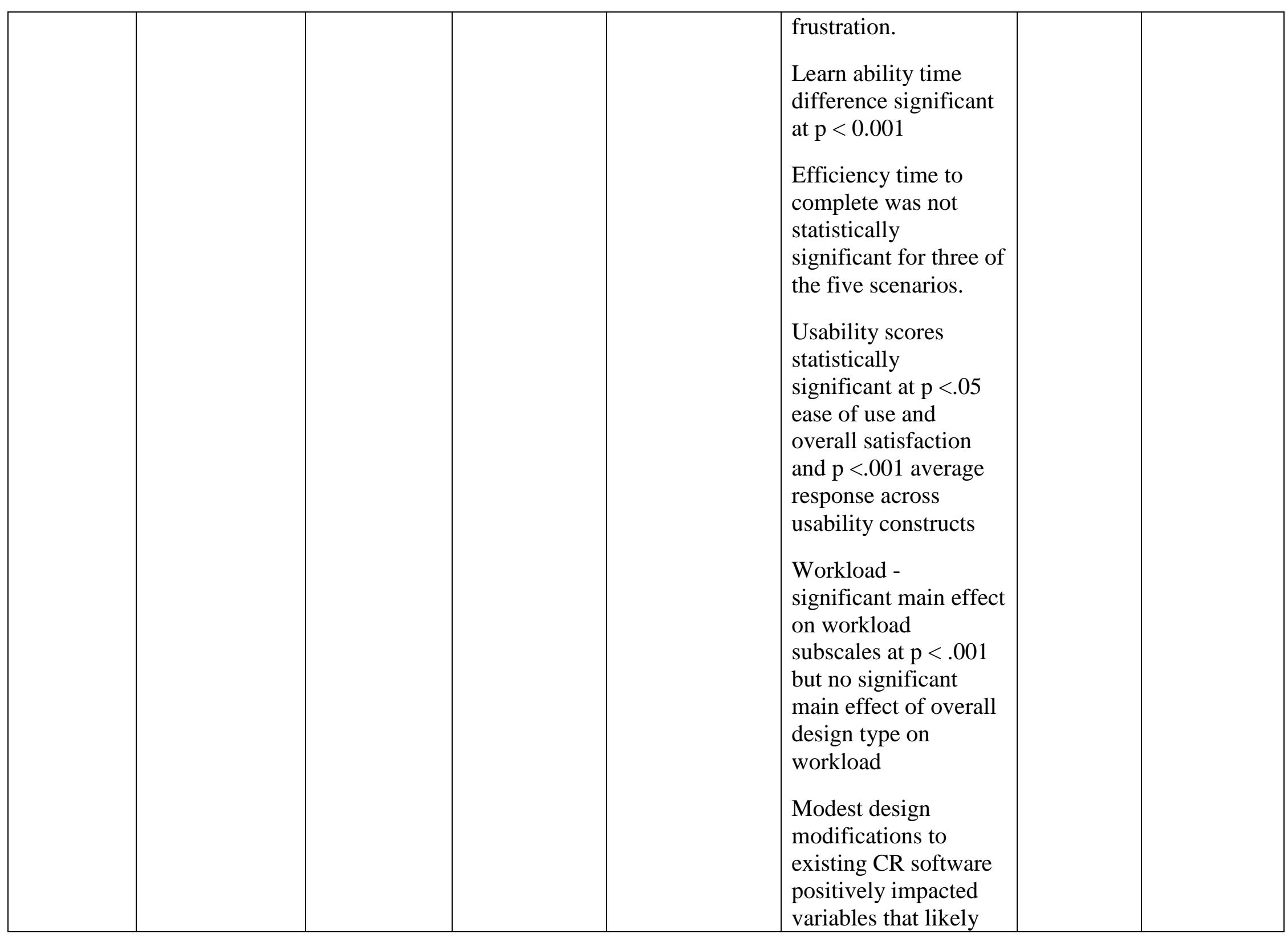




\begin{tabular}{|c|c|c|c|c|}
\hline & & & & $\begin{array}{l}\text { increase the } \\
\text { willingness for first- } \\
\text { time nursing users to } \\
\text { adopt and consistently } \\
\text { use CR } \\
\text { Designed to address } \\
\text { barriers identified in } \\
\text { previous study: learn } \\
\text { ability, efficiency, } \\
\text { usability, and } \\
\text { workload }\end{array}$ \\
\hline $\begin{array}{l}\text { Saleem; } \\
2004\end{array}$ & $\begin{array}{l}\text { Outpatient } \\
\text { primary care } \\
\text { clinics in } 4 \text { VA } \\
\text { Medical } \\
\text { Centers }\end{array}$ & $\begin{array}{l}35 \text { nurses } \\
\text { and } 55 \\
\text { physicians } \\
\text { mid-level } \\
\text { practitioners }\end{array}$ & $\begin{array}{l}\text { Observational } \\
\text { study }\end{array}$ & $\begin{array}{l}\text { Barriers to using } \\
\text { system optimally } \\
\text { included: lack of } \\
\text { coordination between } \\
\text { nurses and providers, } \\
\text { using the reminders } \\
\text { while not with the } \\
\text { patient which } \\
\text { impaired data } \\
\text { acquisition and/or } \\
\text { implementation of } \\
\text { recommended actions, } \\
\text { workload, lack of } \\
\text { reminder flexibility, } \\
\text { and poor interface } \\
\text { usability. } \\
\text { Facilitators included: } \\
\text { limiting number of } \\
\text { reminders at a site, } \\
\text { strategic location of }\end{array}$ \\
\hline
\end{tabular}




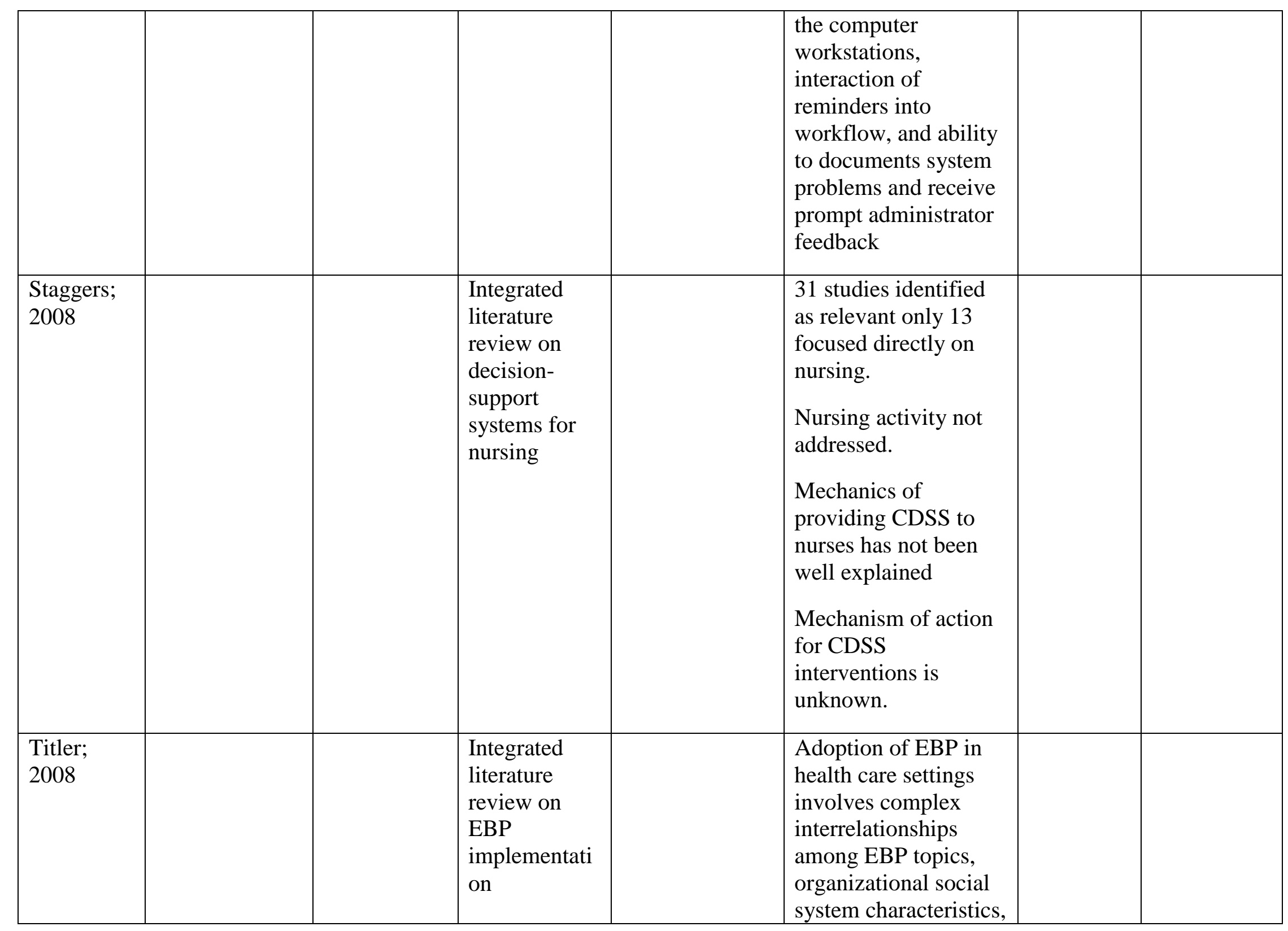




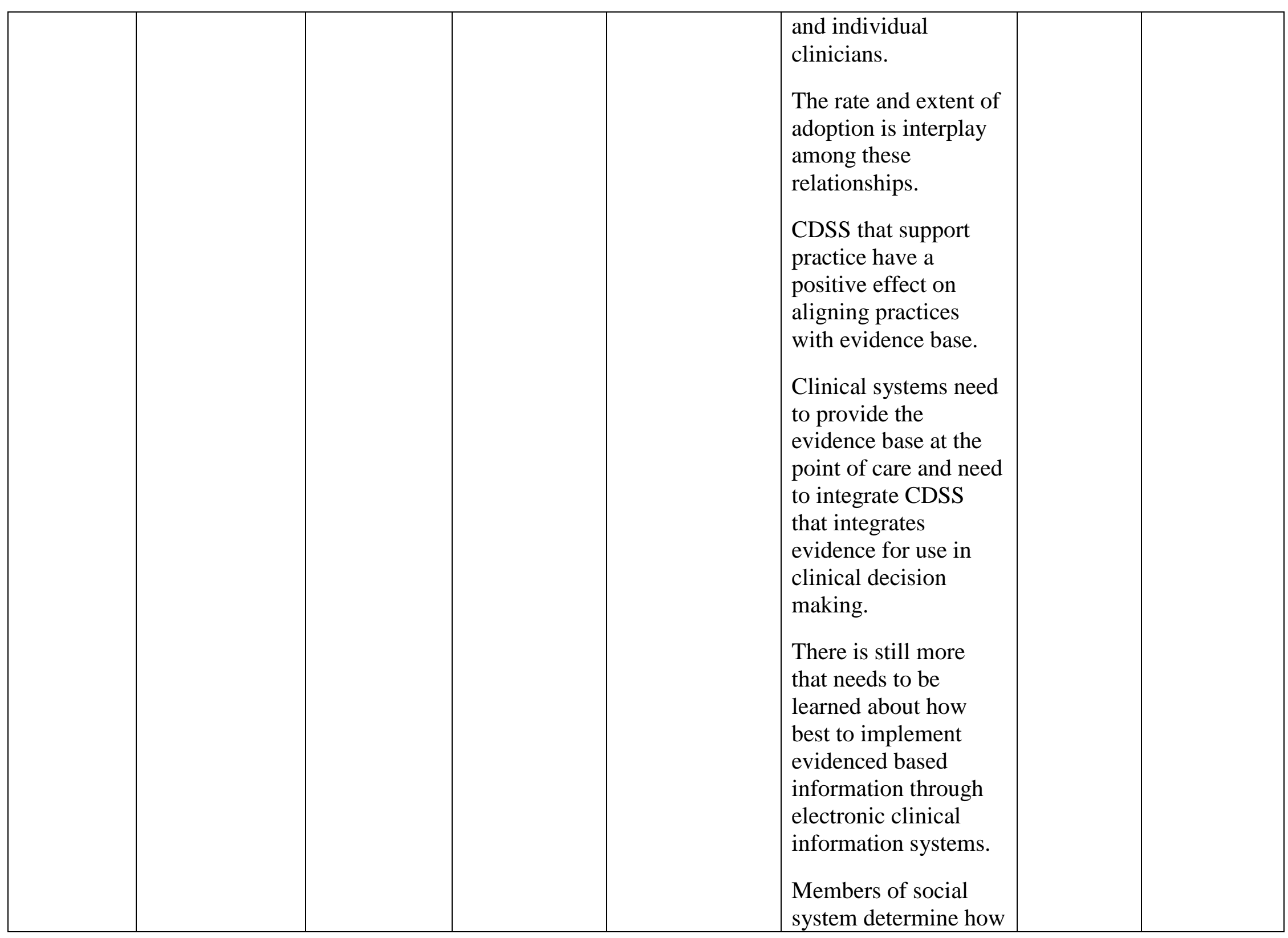




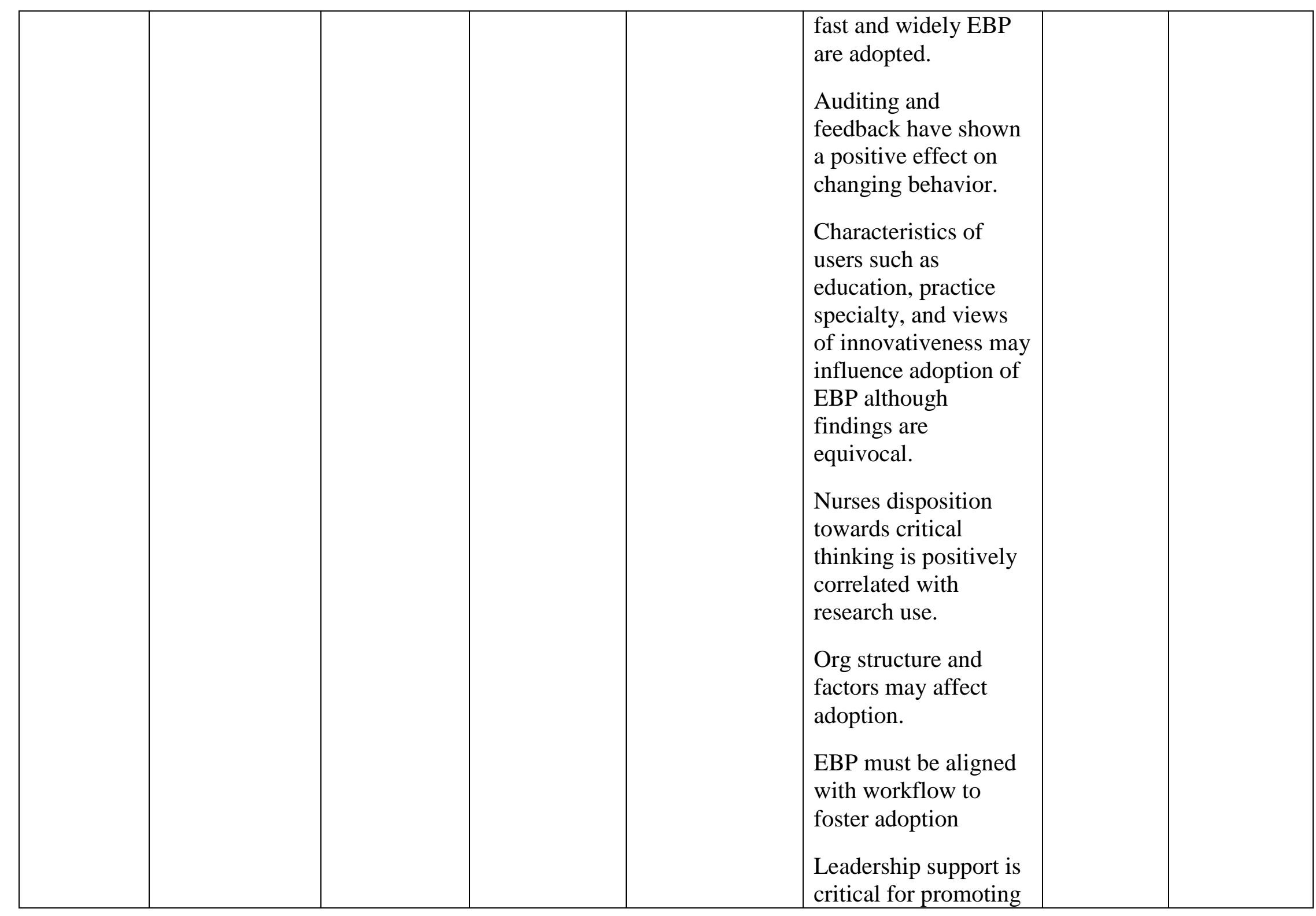




\begin{tabular}{|c|c|c|c|c|}
\hline & & & & use EBP \\
\hline $\begin{array}{l}\text { Weber; } \\
2009\end{array}$ & $\begin{array}{l}\text { Critical care } \\
\text { units }\end{array}$ & $\begin{array}{l}33 \text { nurses } \\
(23) \text { and } \\
\text { physicians } \\
(10) \\
\text { interviewed } \\
\text { regarding } \\
\text { the } \\
\text { APACHE III } \\
\text { CDSS }\end{array}$ & $\begin{array}{l}\text { Qualitative } \\
\text { descriptive } \\
\text { using } \\
\text { grounded } \\
\text { theory }\end{array}$ & $\begin{array}{l}\text { Nurses and physicians } \\
\text { are motivated to use } \\
\text { system when it allows } \\
\text { them to forecast } \\
\text { potential outcomes of } \\
\text { decisions prior to } \\
\text { actually making those } \\
\text { decisions. } \\
\text { When system decision } \\
\text { was congruent with } \\
\text { that of clinician } \\
\text { prediction the } \\
\text { clinician was more } \\
\text { likely to incorporate } \\
\text { the system } \\
\text { recommendation into } \\
\text { practice. } \\
\text { Nurses were more apt } \\
\text { to use system once } \\
\text { they found out they } \\
\text { could use the data to } \\
\text { influence physician } \\
\text { decisions. } \\
\text { System was used to } \\
\text { support or back-up } \\
\text { the clinical decisions } \\
\text { that were made. }\end{array}$ \\
\hline
\end{tabular}




\begin{tabular}{|c|c|c|c|c|c|c|}
\hline $\begin{array}{l}\text { Weir; } \\
2007\end{array}$ & $\begin{array}{l}10 \text { Veterans } \\
\text { Administration } \\
\text { Medical } \\
\text { Centers }\end{array}$ & $\begin{array}{l}88 \text { primary } \\
\text { care } \\
\text { clinicians; } \\
14 \text { nurses, } \\
53 \\
\text { physicians, } 8 \\
\text { pharmacists, } \\
2 \text { dieticians, } \\
3 \text { clerks, and } \\
8 \text { social } \\
\text { workers }\end{array}$ & $\begin{array}{l}\text { Observation } \\
\text { and semi- } \\
\text { structure } \\
\text { interviews }\end{array}$ & $\begin{array}{l}\text { Semi-structure } \\
\text { interview guide }\end{array}$ & $\begin{array}{l}\text { System must be } \\
\text { designed to allow for } \\
\text { fast and accurate } \\
\text { decisions. }\end{array}$ & $\begin{array}{l}\text { Multiple } \\
\text { site study } \\
\text { interviewi } \\
\text { ng } \\
\text { multiple } \\
\text { types and } \\
\text { levels of } \\
\text { clinicians }\end{array}$ \\
\hline
\end{tabular}




\section{Appendix B}

Missed Nursing Care Literature Review Matrix 
Missed Nursing Care Literature Review Matrix

\begin{tabular}{|c|c|c|c|c|c|c|c|}
\hline Source & Setting & Sample & Design & Instruments & Key Findings & Strengths & Limitations \\
\hline $\begin{array}{l}\text { Al- } \\
\text { Kandari } \\
\text { and } \\
\text { Thomas, } \\
2009\end{array}$ & $\begin{array}{l}\text { Medical } \\
\text { surgical } \\
\text { units in } 5 \\
\text { governmen } \\
\text { t general } \\
\text { hospitals in } \\
\text { Kuwait }\end{array}$ & 780 nurses & $\begin{array}{l}\text { Exploratory } \\
\text { survey }\end{array}$ & $\begin{array}{l}\text { International } \\
\text { Hospital } \\
\text { Outcomes } \\
\text { Survey }\end{array}$ & $\begin{array}{l}\text { The most common nursing } \\
\text { activities that nurses were } \\
\text { unable to complete } \\
\text { included: (1) comfort talk } \\
\text { with patient and family, (2) } \\
\text { adequate documentation of } \\
\text { nursing care, (3) oral care, } \\
\text { (4) routine catheter care, } \\
\text { and (5) starting or } \\
\text { changing IV fluid on time. } \\
\text { The results that nursing } \\
\text { activities were completed } \\
\text { more often when the } \\
\text { patient to nurse ratio was } \\
\text { less than five. Bivariate } \\
\text { analysis was used to } \\
\text { examine the relationship } \\
\text { between task completion } \\
\text { and demographic variables. } \\
\text { T analyses indicated that } \\
\text { the he nurses' educational } \\
\text { background and age was } \\
\text { related to completion of } \\
\text { nursing care activities. } \\
\text { Gender had no influence } \\
\text { on nursing care activity } \\
\text { completion. }\end{array}$ & & $\begin{array}{l}\text { Conducted in } 5 \\
\text { hospitals in } \\
\text { Kuwait. Self- } \\
\text { report by } \\
\text { nurses. }\end{array}$ \\
\hline
\end{tabular}




\begin{tabular}{|c|c|c|c|c|c|c|c|}
\hline $\begin{array}{l}\text { Gravlin, } \\
2010\end{array}$ & $\begin{array}{l}16 \\
\mathrm{med} / \mathrm{surg} \\
\text { units in } 3 \\
\text { hospitals in } \\
\text { northeast. }\end{array}$ & $\begin{array}{l}241 \mathrm{RNs} \\
\text { and } 99 \\
\text { NAs, } \\
42.6 \% \\
\text { response } \\
\text { rate }\end{array}$ & $\begin{array}{l}\text { Quantitative } \\
\text { survey } \\
\text { design }\end{array}$ & $\begin{array}{l}\text { MISSCARE } \\
\text { Survey 2; } \\
\text { delegation } \\
\text { questionnaire }\end{array}$ & $\begin{array}{l}\text { Most frequently missed } \\
\text { care items were } \\
\text { ambulation, turning, } \\
\text { feeding, and mouth care. } \\
\text { Top six reasons for missed } \\
\text { care were related to labor } \\
\text { resource factors included: } \\
\text { unexpected rise in patient } \\
\text { acuity or volume, heavy } \\
\text { discharge/admission } \\
\text { activity, level of staffing, } \\
\text { and urgent patient } \\
\text { situations. } \\
\text { Top } 3 \text { reasons were related } \\
\text { to nurses ability to manage } \\
\text { patient flow and rapidly } \\
\text { changing patient and unit } \\
\text { needs. Additionally, RNs } \\
\text { cites communication with } \\
\text { the NA that care was not } \\
\text { completed as a factor. } \\
\text { Communication } \\
\text { breakdowns were also } \\
\text { noted as a reason for } \\
\text { increased missed care. } \\
88 \% \text { of nurse managers } \\
\text { reported that care omission } \\
\text { had been reported to them } \\
\text { by staff. Of those with } \\
\text { reports, 66.7\% reported the } \\
\text { occurrence of the omission }\end{array}$ & $\begin{array}{l}\text { Finding } \\
\text { consistent } \\
\text { with } \\
\text { previous } \\
\text { studies } \\
\text { conducted } \\
\text { by Kalisch } \\
\text { et al. }\end{array}$ & \begin{tabular}{|l|} 
Study \\
conducted in 3 \\
hospitals, small \\
convenience \\
sample
\end{tabular} \\
\hline
\end{tabular}




\begin{tabular}{|c|c|c|c|c|c|}
\hline & & & & & as frequent. \\
\hline $\begin{array}{l}\text { Kalisch, } \\
2006\end{array}$ & $\begin{array}{l}\text { Medical } \\
\text { surgical } \\
\text { units in } \\
\text { two } \\
\text { hospitals }\end{array}$ & $\begin{array}{l}107 \text { RNs, } \\
15 \text { LPNs, } \\
\text { and } 51 \\
\text { NAs } \\
25 \text { focus } \\
\text { groups }\end{array}$ & $\begin{array}{l}\text { Qualitative } \\
\text { study } \\
\text { utilizing } \\
\text { focus } \\
\text { groups }\end{array}$ & Not stated & $\begin{array}{l}\text { Missed nursing care: } \\
\text { nurses responded that they } \\
\text { were not always able to } \\
\text { provide the needed care for } \\
\text { each patient. The } \\
\text { participants reported a high } \\
\text { level of guilt and regret } \\
\text { when not able to care for } \\
\text { their patients. } \\
9 \text { themes of regularly } \\
\text { missed care emerged from } \\
\text { analysis: } \\
\\
\text { (1) Ambulation, (2) } \\
\text { Turning, (3) Delayed or } \\
\text { missed feedings, (4) } \\
\text { patient education, (5) } \\
\text { discharge planning, (6) } \\
\text { emotional support, (7) } \\
\text { hygiene, (8) intake and } \\
\text { output documentation and } \\
\text { (9) surveillance } \\
7 \text { themes for the reasons } \\
\text { for missed care emerged }\end{array}$ \\
\hline
\end{tabular}




\begin{tabular}{|c|c|c|c|c|c|c|}
\hline & & & & & $\begin{array}{l}\text { from the analysis: } \\
\text { (1) too few staff, (2) time } \\
\text { required for a nursing } \\
\text { intervention, (3) poor use } \\
\text { of existing staff resources, } \\
\text { (4) not my job syndrome, } \\
\text { (5) ineffective delegation, } \\
\text { (6) habit, and (7) denial }\end{array}$ & \\
\hline $\begin{array}{l}\text { Kalisch, } \\
\text { Landstro } \\
\text { m, } \\
\text { Hinshaw, } \\
2009\end{array}$ & $\begin{array}{l}\text { Theoretical } \\
\text { paper }\end{array}$ & $\begin{array}{l}\text { Theoretical } \\
\text { paper; } \\
\text { grounded } \\
\text { in research } \\
\text { literature of } \\
\text { nursing and } \\
\text { healthcare }\end{array}$ & $\begin{array}{l}\text { Concept } \\
\text { analysis of } \\
\text { missed } \\
\text { nursing care }\end{array}$ & $\begin{array}{l}\text { Used Walker } \\
\text { and Avant's } \\
\text { modified } 8 \\
\text { step process } \\
\text { from Wilson }\end{array}$ & $\begin{array}{l}\text { No definition of missed } \\
\text { care found in literature; } \\
\text { similar concept } \\
\text { "unfinished" care } \\
\text { discussed by Sochalski } \\
\text { (2004). Other studies } \\
\text { examined effects of missed } \\
\text { care, but did not address it } \\
\text { directly. } \\
\text { Missed care is } \\
\text { conceptualized as a } \\
\text { universal phenomenon and } \\
\text { is generalizable to multiple } \\
\text { clinical settings. } \\
\text { Antecedents to missed care } \\
\text { include: labor resources, } \\
\text { material resources, and } \\
\text { communication and } \\
\text { teamwork witch interact } \\
\text { with the nursing process } \\
\text { and the nurses own internal } \\
\text { processes. }\end{array}$ & $\begin{array}{l}\text { Based on } \\
\text { limited research } \\
\text { primarily one } \\
\text { study conducted } \\
\text { by Kalisch } \\
(2006)\end{array}$ \\
\hline
\end{tabular}




\begin{tabular}{|c|c|c|c|c|c|c|}
\hline & & & & & $\begin{array}{l}\text { Consequences of missed } \\
\text { nursing care are threats to } \\
\text { patient safety. } \\
\text { Missed nursing care is } \\
\text { defined as any aspect of } \\
\text { required patient care that is } \\
\text { omitted (either in part or } \\
\text { whole) or delayed. } \\
\text { Missed nursing care is an } \\
\text { error of omission. }\end{array}$ & \\
\hline $\begin{array}{l}\text { Kalisch } \\
\text { and } \\
\text { Williams, } \\
2009\end{array}$ & $\begin{array}{l}35 \text { medical, } \\
\text { surgical, } \\
\text { rehab, and } \\
\text { ICU units } \\
\text { in } 4 \text { acute } \\
\text { care } \\
\text { hospitals }\end{array}$ & $\begin{array}{l}459 \text { and } \\
639 \text { staff } \\
\text { nurses in } \\
\text { two studies }\end{array}$ & $\begin{array}{l}\text { Developmen } \\
\mathrm{t} \text { and } \\
\text { psychometri } \\
\mathrm{c} \text { testing of } \\
\text { MISSCARE } \\
\text { survey }\end{array}$ & $\begin{array}{l}\text { MISSCARE } \\
\text { survey }\end{array}$ & $\begin{array}{l}\text { The Missed Nursing Care } \\
\text { Survey (MISSCARE) is a } \\
\text { two-part survey developed } \\
\text { by Beatrice Kalisch in } \\
\text { 2009. In the proposed } \\
\text { study, only part A of the } \\
\text { survey will be used (see } \\
\text { Table 1). Part A of the } \\
\text { survey contains 22-items } \\
\text { that are designed to } \\
\text { measure elements of } \\
\text { missed nursing care } \\
\text { (Kalisch \& Williams, } \\
\text { 2009). Part A of the tool } \\
\text { asks the participants to rate } \\
\text { the frequency of missed } \\
\text { nursing care on their unit, } \\
\text { including themselves } \\
\text { (Kalisch \& Williams, }\end{array}$ & $\begin{array}{l}\text { Study only } \\
\text { conducted in } 4 \\
\text { hospitals, self- } \\
\text { report may } \\
\text { include bias, } \\
\text { actual care was } \\
\text { on observed. }\end{array}$ \\
\hline
\end{tabular}




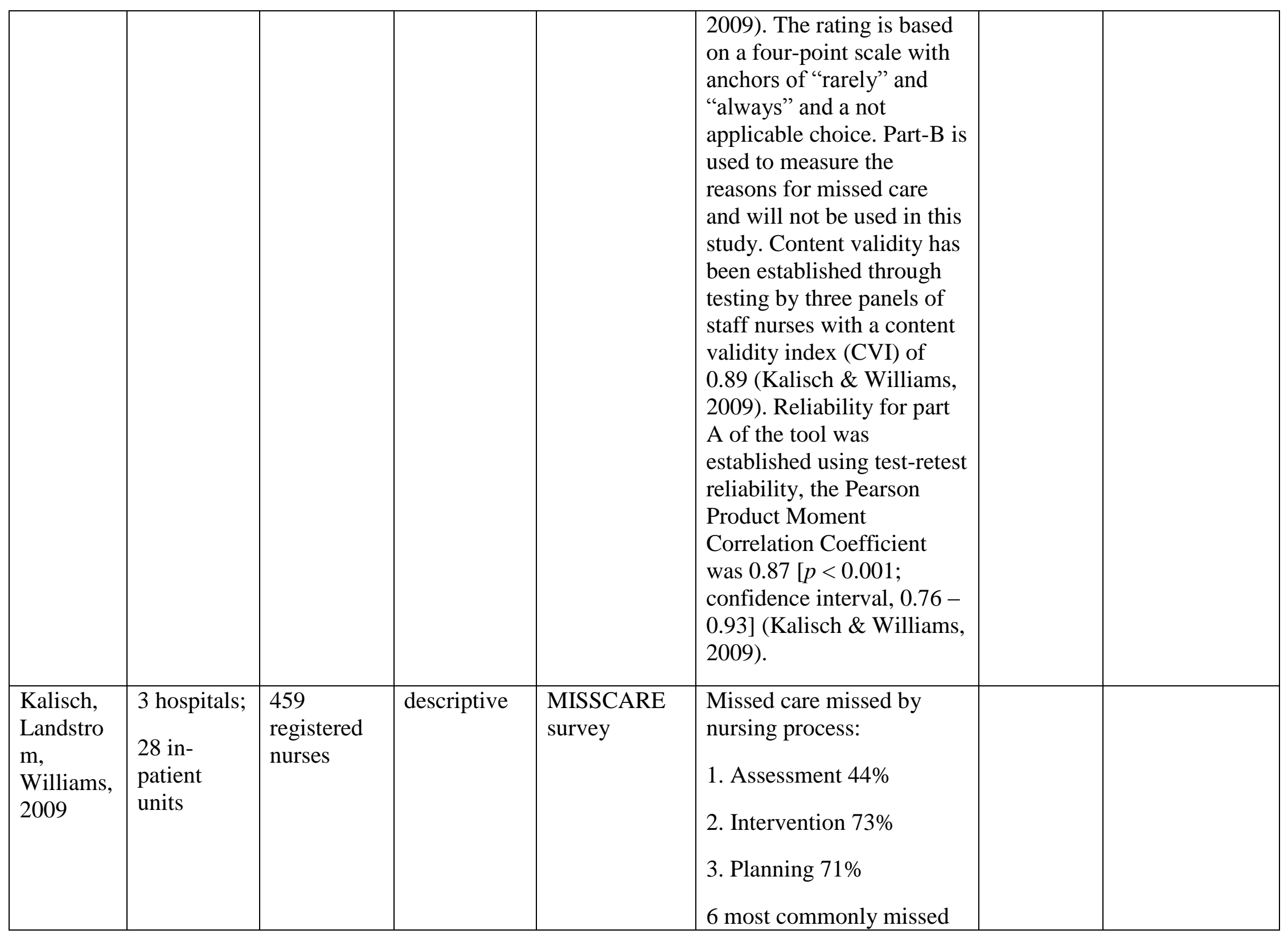




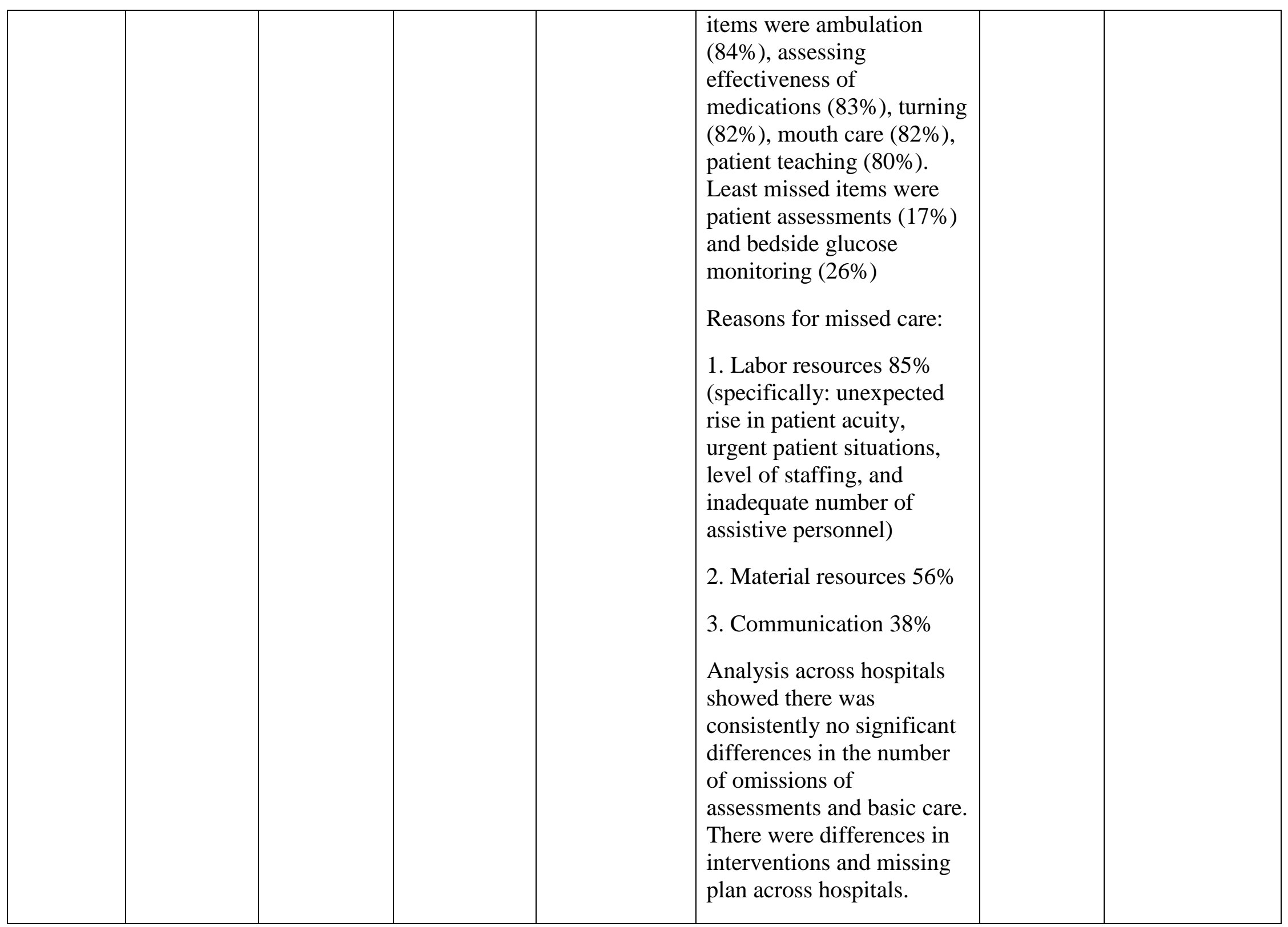




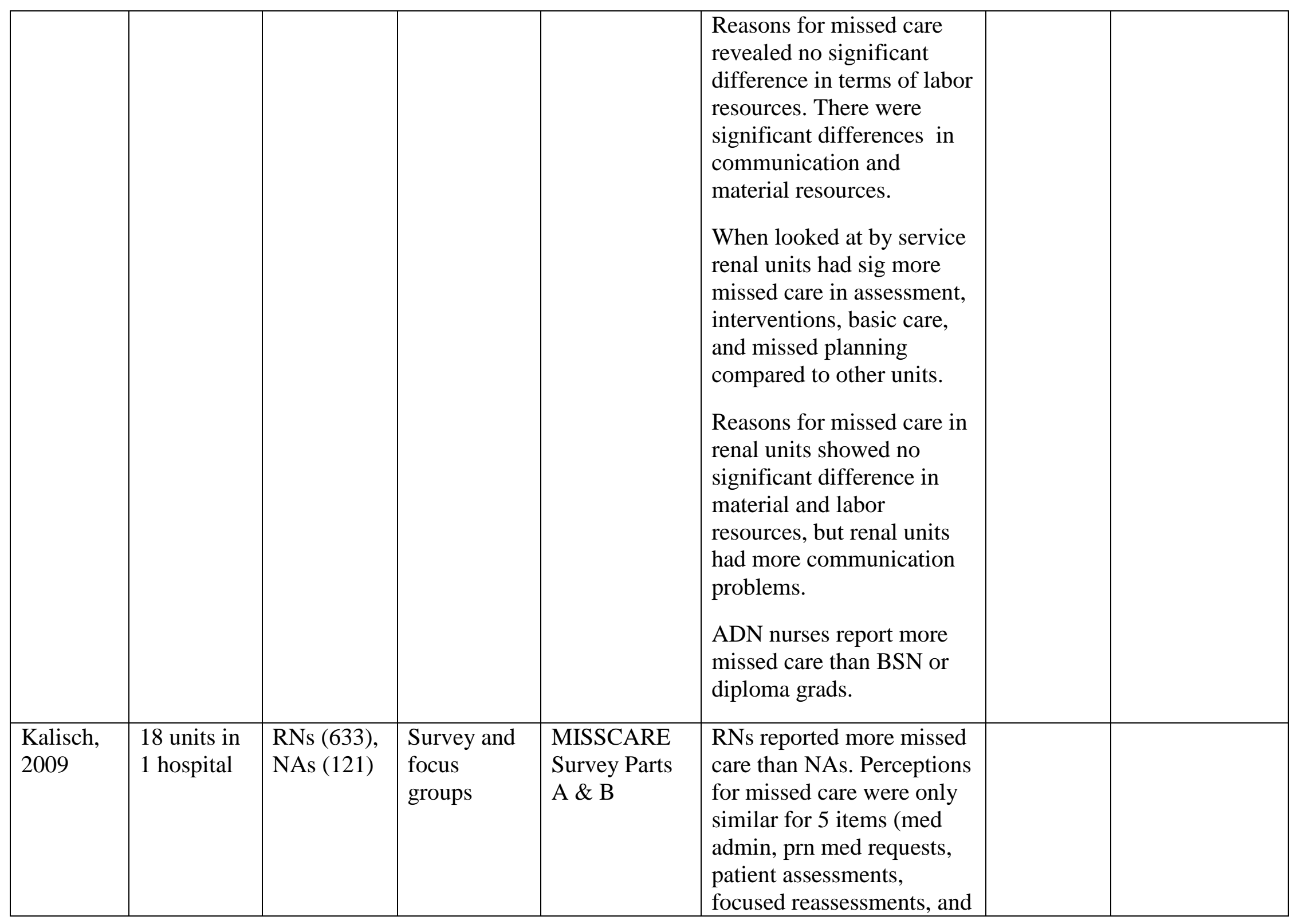




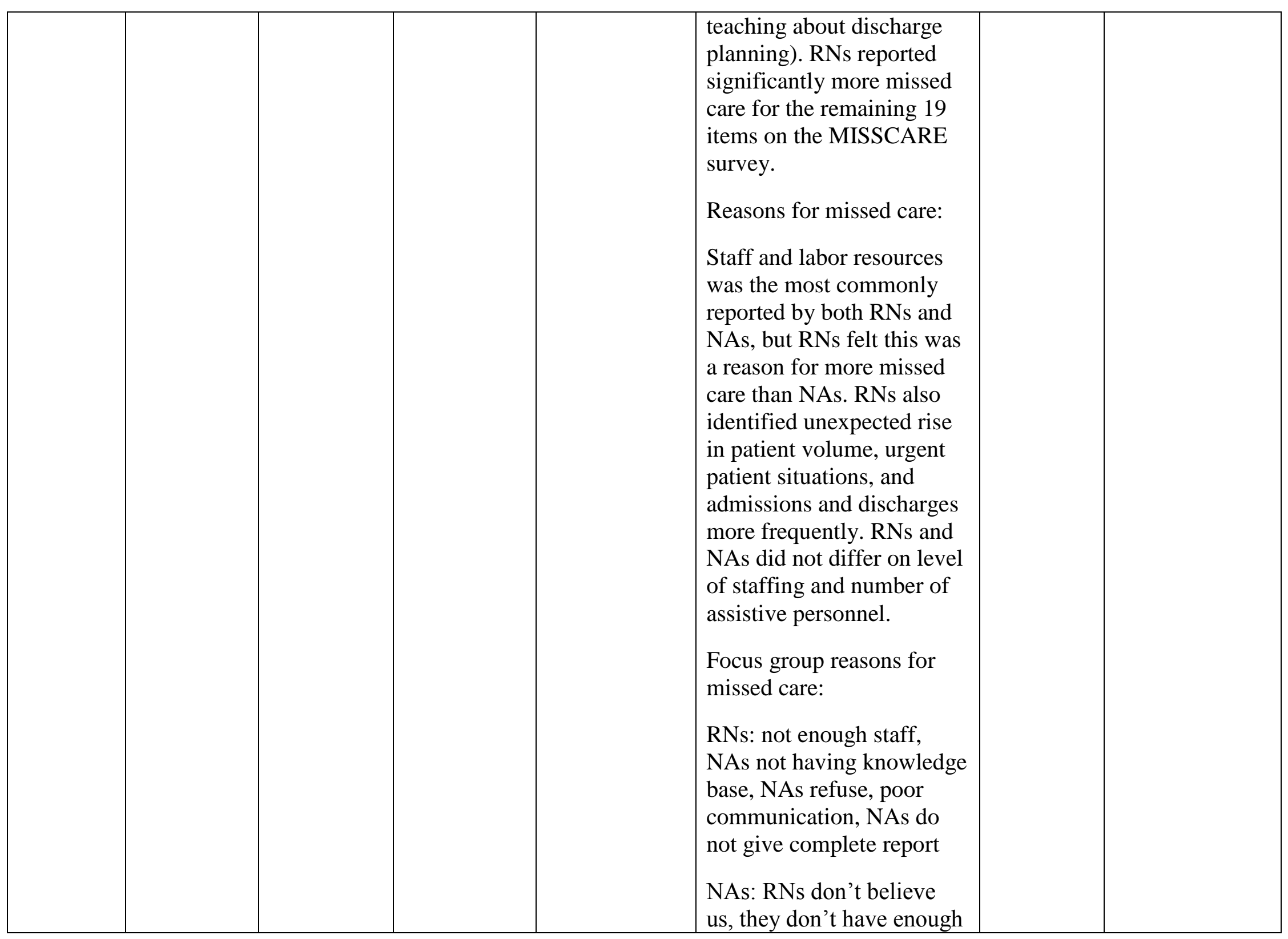




\begin{tabular}{|c|c|c|c|c|c|c|}
\hline & & & & & $\begin{array}{l}\text { time, RNs do not listen, no } \\
\text { or late report }\end{array}$ & \\
\hline $\begin{array}{l}\text { Tschanne } \\
\mathrm{n}, \\
\text { Kalisch, } \\
\text { and Lee, } \\
2010\end{array}$ & $\begin{array}{l}10 \\
\text { hospitals, } \\
110 \\
\text { medical, } \\
\text { surgical, } \\
\text { rehab, } \\
\text { intermediat } \\
\text { e and } \\
\text { intensive } \\
\text { care units } \\
\text { in Midwest }\end{array}$ & $\begin{array}{l}\text { RNs 3143, } \\
\text { LPNs 83, } \\
\text { and NAs } \\
943\end{array}$ & $\begin{array}{l}\text { Cross- } \\
\text { sectional } \\
\text { descriptive } \\
\text { study }\end{array}$ & $\begin{array}{l}\text { MISSCARE } \\
\text { survey; } \\
\text { Collection of } \\
\text { turnover, } \\
\text { intent to } \\
\text { leave, and } \\
\text { staffing data }\end{array}$ & $\begin{array}{l}\text { Bivariate analysis } \\
\text { indicated that larger } \\
\text { amounts of missed care } \\
\text { was associated with higher } \\
\text { turnover rates. Larger } \\
\text { amounts of missed care } \\
\text { were associated with } \\
\text { greater intention to leave. } \\
\text { Multiple regression } \\
\text { analysis indicated that : } \\
\text { Missed care was not found } \\
\text { to be a predictor of nurse } \\
\text { turnover, but was found to } \\
\text { be a predictor of intention } \\
\text { to leave. }\end{array}$ & $\begin{array}{l}\text { Hospitals of } \\
\text { similar size and } \\
\text { location. } \\
\text { Measure of } \\
\text { missed care is } \\
\text { based on } \\
\text { perceptions }\end{array}$ \\
\hline $\begin{array}{l}\text { Kalisch } \\
\text { and Lee, } \\
2010\end{array}$ & $\begin{array}{l}50 \text { medical, } \\
\text { surgical, } \\
\text { intermediat } \\
\text { e, intensive } \\
\text { care, and } \\
\text { rehab units } \\
\text { in } 4 \\
\text { hospitals } \\
\text { located in } \\
\text { the } \\
\text { midwest }\end{array}$ & $\begin{array}{l}1719 \mathrm{RNs}, \\
491 \mathrm{NAs}\end{array}$ & $\begin{array}{l}\text { Cross- } \\
\text { sectional } \\
\text { descriptive } \\
\text { study }\end{array}$ & $\begin{array}{l}\text { MISSCARE } \\
\text { Survey and } \\
\text { Nursing } \\
\text { Teamwork } \\
\text { Survey }\end{array}$ & $\begin{array}{l}\text { Teamwork scores varied } \\
\text { significantly by unit, ICUs } \\
\text { had higher teamwork } \\
\text { scores than the other units. } \\
\text { Negative relationship } \\
\text { between missed care mean } \\
\text { scores and teamwork were } \\
\text { significant ( } \mathrm{r}-.37, \mathrm{p}<.01) \text {. } \\
\text { More missed care was } \\
\text { associated with trust, team } \\
\text { orientation, shared mental } \\
\text { model, and team } \\
\text { leadership. The higher the }\end{array}$ & \\
\hline
\end{tabular}




\begin{tabular}{|c|c|c|c|c|c|c|}
\hline & & & & & $\begin{array}{l}\text { score on the NTS the less } \\
\text { missed care. } \\
\text { Predictors of missed care: } \\
\text { RNs, those with tenures } \\
\text { greater than equal to } 5 \\
\text { years, absenteeism, and } \\
\text { staffing adequacy. }\end{array}$ & \\
\hline $\begin{array}{l}\text { Kalisch, } \\
\text { Tschanne } \\
\text { n, and } \\
\text { Lee, } 2011\end{array}$ & $\begin{array}{l}10 \\
\text { hospitals, } \\
110 \\
\text { medical, } \\
\text { surgical, } \\
\text { rehab, } \\
\text { intermediat } \\
\text { e and } \\
\text { intensive } \\
\text { care units } \\
\text { in Midwest }\end{array}$ & $\begin{array}{l}4288, \mathrm{RNs} \\
(73.5 \%), \\
\text { LPNs } \\
(1.9 \%), \mathrm{NA} \\
(22 \%), \\
\text { Nurse } \\
\text { Manager } \\
(2.5 \%)\end{array}$ & $\begin{array}{l}\text { Cross- } \\
\text { sectional } \\
\text { descriptive } \\
\text { study }\end{array}$ & $\begin{array}{l}\text { MISSCARE } \\
\text { survey, } \\
\text { HPPD, Skill } \\
\text { mix, } \\
\text { education and } \\
\text { experience, } \\
\text { absenteeism, } \\
\text { CMI }\end{array}$ & $\begin{array}{l}\text { HPPD was a significant } \\
\text { predictor of missed nursing } \\
\text { care, other variables in the } \\
\text { model experience ( }>5 \text { yrs), } \\
\text { absenteeism, CMI, and } 9 \\
\text { dummy hospital variables } \\
\text { explained } 29.4 \% \text { of the } \\
\text { variance in the model, but } \\
\text { only HPPD was } \\
\text { significant. Missed nursing } \\
\text { care may explain, in part, } \\
\text { the relationship between } \\
\text { staffing levels and patient } \\
\text { outcomes. HHPD and } \\
\text { RNHPPD were negatively } \\
\text { associated with missed } \\
\text { care. Greater absenteeism } \\
\text { was associated with higher } \\
\text { missed care. Higher CMI } \\
\text { was associated with lower } \\
\text { missed care. }\end{array}$ & \\
\hline $\begin{array}{l}\text { Kalisch, } \\
\text { Tschanne } \\
\text { n, Lee, }\end{array}$ & $\begin{array}{l}10 \\
\text { hospitals, } \\
110\end{array}$ & $\begin{array}{l}\text { RNs } \\
(3143),\end{array}$ & $\begin{array}{l}\text { Survey } \\
\text { method }\end{array}$ & $\begin{array}{l}\text { MISSCARE } \\
\text { Survey Part A }\end{array}$ & $\begin{array}{l}\text { Amount and type of } \\
\text { missed care: }\end{array}$ & $\begin{array}{l}\text { Collected from } \\
\text { self-response } \\
\text { survey; not }\end{array}$ \\
\hline
\end{tabular}




\begin{tabular}{|c|c|c|c|c|c|}
\hline $\begin{array}{l}\text { and } \\
\text { Friese, } \\
2011\end{array}$ & $\begin{array}{l}\text { medical, } \\
\text { surgical, } \\
\text { rehab, } \\
\text { intermediat } \\
\text { e and } \\
\text { intensive } \\
\text { care units } \\
\text { in Midwest }\end{array}$ & NAs (943) & $\& B$ & $\begin{array}{l}\text { Frequently or always } \\
\text { missed: } \\
\text { Ambulation (32.7\%), } \\
\text { attendance at care } \\
\text { conferences (31.8\%), and } \\
\text { mouth care (25.5\%). } \\
\text { Items occasionally or } \\
\text { rarely missed: } \\
\text { Patient assessments } \\
\text { (97.7\%), glucose } \\
\text { monitoring ( } 97.6 \%) \text {, and } \\
\text { vital signs ( } 95.8 \%) \\
\text { Reasons for most missed } \\
\text { care: } \\
\text { Inadequate labor resources } \\
\text { (93.1\%), material } \\
\text { resources ( } 89.6 \%) \text {, and } \\
\text { communication ( } 81.7 \%) . \\
\text { In regard to labor resources } \\
\text { unexpected rise in acuity } \\
\text { or patient volume was the } \\
\text { top reason ( } 94.9 \%) . \\
\text { Medications missing in } \\
\text { materials resources } \\
(94.6 \%), \text { and } \\
\text { communication } \\
\text { specifically unbalanced } \\
\text { patient assignments ( } 91 \%) \\
8 \text { variables associated with }\end{array}$ & $\begin{array}{l}\text { certain that all } \\
\text { possible } \\
\text { explanatory } \\
\text { variables } \\
\text { present in } \\
\text { model }\end{array}$ \\
\hline
\end{tabular}




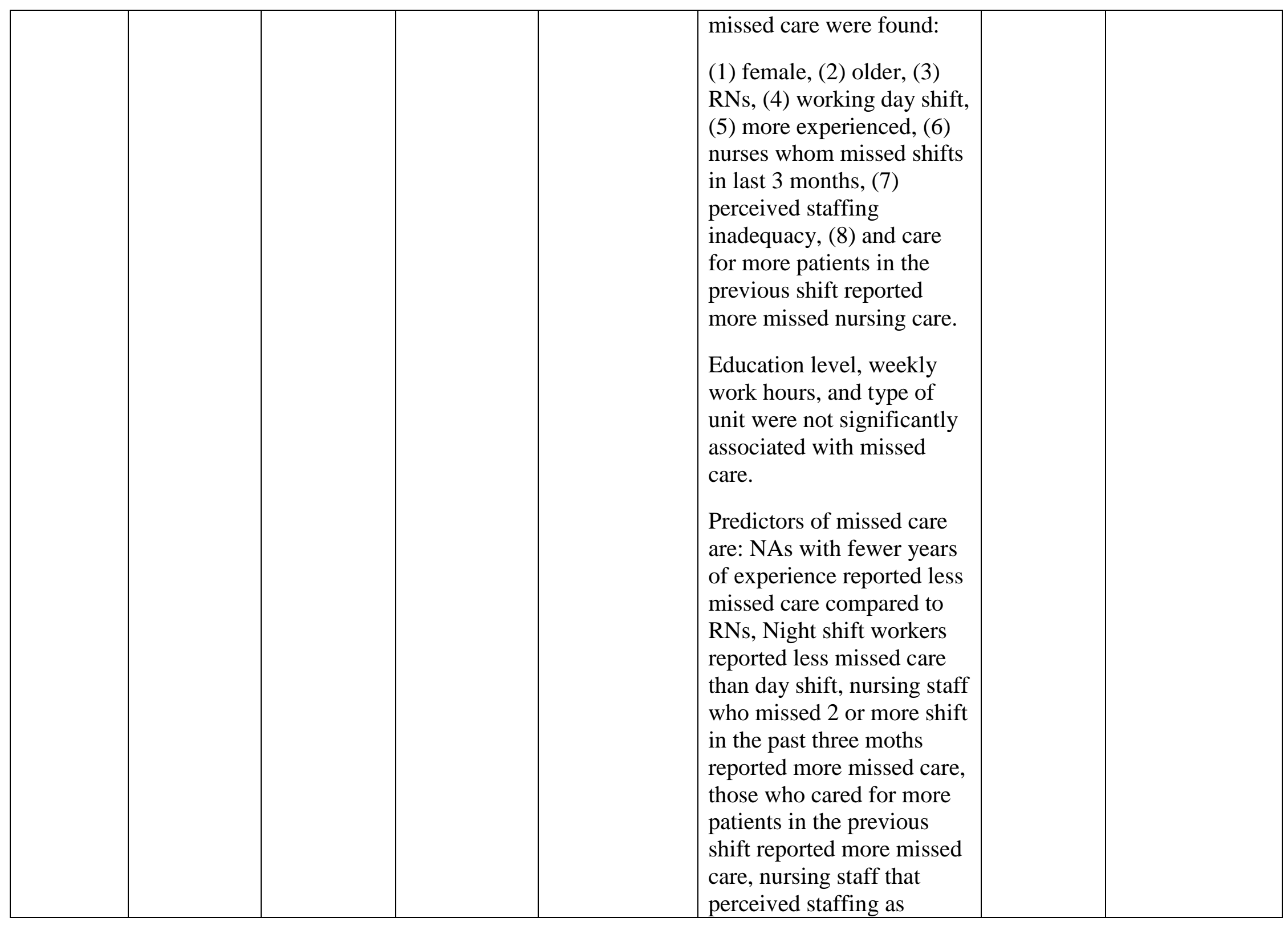




\begin{tabular}{|c|c|c|c|c|c|c|}
\hline & & & & & $\begin{array}{l}\text { adequate reported less } \\
\text { missed care, and age and } \\
\text { sex were not sig associated } \\
\text { with missed care. }\end{array}$ & \\
\hline $\begin{array}{l}\text { Kalisch, } \\
\text { Tschanne } \\
\text { n, Lee, } \\
\text { and } \\
\text { Salsgiver; } \\
2011\end{array}$ & $\begin{array}{l}10 \\
\text { hospitals, } \\
110 \\
\text { medical, } \\
\text { surgical, } \\
\text { rehab, } \\
\text { intermediat } \\
\text { e and } \\
\text { intensive } \\
\text { care units } \\
\text { in Midwest }\end{array}$ & $\begin{array}{l}3135 \mathrm{RNs} \\
\text { and } 939 \\
\text { NAs }\end{array}$ & Survey & $\begin{array}{l}\text { MISSCARE } \\
\text { survey }\end{array}$ & $\begin{array}{l}\text { Nursing staff reporting less } \\
\text { missed nursing care had } \\
\text { great satisfaction with their } \\
\text { job and occupation. In both } \\
\text { models staffing adequacy } \\
\text { and missed care were } \\
\text { significant predictors of } \\
\text { satisfaction. Perceptions of } \\
\text { staffing adequacy were a } \\
\text { sig predictor for both } \\
\text { satisfaction variables. } \\
\text { Nurses on ICUs were more } \\
\text { satisfied than those on } \\
\text { rehab units. }\end{array}$ & $\begin{array}{l}\text { Hospitals of } \\
\text { similar size and } \\
\text { location. } \\
\text { Measure of } \\
\text { missed care is } \\
\text { based on } \\
\text { perceptions }\end{array}$ \\
\hline $\begin{array}{l}\text { Kalisch, } \\
\text { Gosselen, } \\
\text { Choi, } \\
2012\end{array}$ & $\begin{array}{l}10 \text { specific } \\
\text { patient care } \\
\text { units; } 5 \\
\text { units with } \\
\text { highest } \\
\text { ratings of } \\
\text { missed } \\
\text { care and } 5 \\
\text { units with } \\
\text { lowest } \\
\text { ratings of } \\
\text { missed } \\
\text { care (total } \\
\text { of } 5\end{array}$ & $\begin{array}{l}\text { Ten focus } \\
\text { groups } \\
\text { made up of } \\
10 \text { to } 12 \\
\text { RNs }\end{array}$ & $\begin{array}{l}\text { Qualitative } \\
\text { using focus } \\
\text { groups }\end{array}$ & & $\begin{array}{l}10 \text { themes that describe } \\
\text { differences between units } \\
\text { with high and low amounts } \\
\text { of missed nursing care } \\
\text { emerged: } \\
\text { (1) staffing levels and } \\
\text { adaptability, (2) } \\
\text { communication, (3) } \\
\text { collective orientation, (4), } \\
\text { backup, (5) monitoring, (6) } \\
\text { leadership, (7) long tenure, } \\
\text { (8) unit layout, (9) unit }\end{array}$ & \\
\hline
\end{tabular}




\begin{tabular}{|c|c|c|c|c|c|c|}
\hline & $\begin{array}{l}\text { hospitals) } \\
\text { out of } 10 \\
\text { hospitals, } \\
110 \\
\text { medical, } \\
\text { surgical, } \\
\text { rehab, } \\
\text { intermediat } \\
\text { e and } \\
\text { intensive } \\
\text { care units } \\
\text { in Midwest }\end{array}$ & & & & $\begin{array}{l}\text { layout, and (10 trust). } \\
\text { Those with less staffing } \\
\text { ("It gets a little stressful } \\
\text { when we are short...but we } \\
\text { work it out") }\end{array}$ & \\
\hline $\begin{array}{l}\text { Kalisch, } \\
\text { Tschanne } \\
\text { n, Lee, } \\
2012\end{array}$ & $\begin{array}{l}11 \text { acute } \\
\text { care } \\
\text { hospitals } \\
\text { with } 124 \\
\text { units }\end{array}$ & $\begin{array}{l}3432 \mathrm{RNs} \\
\text { and LPNs } \\
\text { and } 980 \\
\text { NAs }\end{array}$ & $\begin{array}{l}\text { Cross } \\
\text { sectional } \\
\text { descriptive } \\
\text { design }\end{array}$ & $\begin{array}{l}\text { MISSCARE } \\
\text { Survey, } \\
\text { HHPD, Fall } \\
\text { rate }\end{array}$ & $\begin{array}{l}\text { HPPD negatively } \\
\text { associated with falls. } \\
\text { Higher missed care scores } \\
\text { were associated with } \\
\text { higher fall rates. Falls were } \\
\text { sig related to the following } \\
\text { elements of missed care: } \\
\text { ambulation, each shift } \\
\text { patient assessment, call } \\
\text { light response, and toilet } \\
\text { assistance. Focused } \\
\text { reassessment and CMI } \\
\text { were not associated with } \\
\text { falls. Missed nursing care } \\
\text { is a mediator of the } \\
\text { relationship between } \\
\text { HPPD and falls. }\end{array}$ & $\begin{array}{l}\text { Only } 11 \\
\text { hospitals } \\
\text { studied in } 2 \\
\text { states. Missed } \\
\text { care based on } \\
\text { perceptions of } \\
\text { nursing staff }\end{array}$ \\
\hline $\begin{array}{l}\text { Kalisch, } \\
\text { McLaugh } \\
\text { lin, }\end{array}$ & $\begin{array}{l}\text { Inpatient in } \\
\text { acute care } \\
\text { hospital in }\end{array}$ & 38 adults & $\begin{array}{l}\text { Qualitative } \\
\text { phenomenol }\end{array}$ & $\begin{array}{l}\text { Semi- } \\
\text { structured } \\
\text { interview }\end{array}$ & $\begin{array}{l}\text { Patients were interviewed } \\
\text { to answer two questions: } \\
\text { (1) What is the patient's }\end{array}$ & \\
\hline
\end{tabular}




\begin{tabular}{|c|c|c|c|c|}
\hline $\begin{array}{l}\text { Dabney, } \\
2012\end{array}$ & $\begin{array}{l}\text { Midwest, } \\
\text { consisted } \\
\text { of seven } \\
\text { different } \\
\text { med/surg } \\
\text { or ICUs }\end{array}$ & ogical & guide & $\begin{array}{l}\text { ability to assess elements } \\
\text { of nursing care? And (2) } \\
\text { To what extent care was } \\
\text { missed? } \\
\text { Items of missed care that } \\
\text { patients could report were } \\
\text { categorized into three areas } \\
\text { (fully reportable, partially } \\
\text { reportable, and not } \\
\text { reportable.) } \\
\text { Fully reportable } \\
\text { Frequently missed (mouth } \\
\text { care, listening, and being } \\
\text { kept informed) } \\
\text { Sometimes missed } \\
\text { (response to call lights, } \\
\text { response to alarms, meal } \\
\text { assistance, and pain } \\
\text { medication and follow-up) } \\
\text { Rarely missed (bathing) } \\
\text { Partially reportable: } \\
\text { Frequently missed } \\
\text { (ambulation, discharge } \\
\text { planning, and patient } \\
\text { education) } \\
\text { Sometimes missed } \\
\text { (medication admin and }\end{array}$ \\
\hline
\end{tabular}




\begin{tabular}{|c|c|c|c|c|c|c|c|}
\hline & & & & & $\begin{array}{l}\text { repositioning) } \\
\text { Rarely missed (vital signs } \\
\text { and hand washing) } \\
\text { Not reportable: (1) patient } \\
\text { assessment, (2) } \\
\text { surveillance, (3) IV site } \\
\text { care. }\end{array}$ & & \\
\hline $\begin{array}{l}\text { Lawless, } \\
2010\end{array}$ & $\begin{array}{l}3 \text { District } \\
\text { Health } \\
\text { Boards in } \\
\text { New } \\
\text { Zealand }\end{array}$ & $\begin{array}{l}1003 \text { staff, } \\
85 \% \\
\text { registered } \\
\text { nurses, } \\
10 \% \\
\text { healthcare } \\
\text { assistants, } \\
5 \% \text { student } \\
\text { nurses }\end{array}$ & Survey & $\begin{array}{l}\text { The Safe } \\
\text { Staffing } \\
\text { Healthy } \\
\text { Workplaces } \\
\text { Survey - } \\
\text { measures } \\
\text { three key } \\
\text { areas: } 1 \text {. } \\
\text { Staffing, } \\
\text { workload, and } \\
\text { quality of } \\
\text { patient care, } \\
\text { 2. Job } \\
\text { satisfaction, } \\
\text { and 3. DHB } \\
\text { responsivenes } \\
\text { s to safe } \\
\text { staffing } \\
\text { healthy } \\
\text { workplace } \\
\text { agenda }\end{array}$ & $\begin{array}{l}\text { 1. Being able to make a } \\
\text { difference is most valued } \\
\text { aspect of job. } \\
\text { 2. Workload/work } \\
\text { intensity is the number one } \\
\text { issue implicated in high } \\
\text { rates of work related stress } \\
\text { leave and intent to leave } \\
\text { 3. Nurses responded to } \\
\text { higher workload/intensity } \\
\text { with increased work effort } \\
\text { and decreased breaks } \\
\text { 4. Nurses recognize unsafe } \\
\text { staffing levels but have } \\
\text { low levels or reporting. } \\
\text { 5. The majority of nurses } \\
\text { do not know what action } \\
\text { has been taken following a } \\
\text { report of a safe staffing } \\
\text { action. } \\
\text { 6. Nurses willing to be }\end{array}$ & $\begin{array}{l}\text { Care } \\
\text { omissions } \\
\text { appear to } \\
\text { be a } \\
\text { universal } \\
\text { phenomen } \\
\text { on across } \\
\text { settings } \\
\text { and } \\
\text { countries. }\end{array}$ & $\begin{array}{l}\text { Low response } \\
\text { rate } 25 \% \\
\text { Did not list the } \\
11 \text { common } \\
\text { patient care } \\
\text { activities } \\
\text { rationed }\end{array}$ \\
\hline
\end{tabular}




\begin{tabular}{|c|c|c|c|c|c|c|}
\hline & & & & & $\begin{array}{l}\text { redeployed to help in } \\
\text { understaffed areas but only } \\
\text { if they are adequately } \\
\text { prepared and their home } \\
\text { staff is not left short. } \\
\text { 7. The majority of nurses } \\
\text { believe their organizations } \\
\text { are taking steps to address } \\
\text { safe staffing. } \\
\text { In regard to rationed care } \\
\text { nurses reported } 11 \\
\text { common patient care } \\
\text { activities all were ranked } \\
\text { as often or very often as } \\
\text { being rationed. Nurses } \\
\text { responded this by working } \\
\text { an increased pace, missing } \\
\text { breaks, staying past shift, } \\
\text { work related stress leave, } \\
\text { changing jobs, or leaving } \\
\text { nursing. }\end{array}$ & \\
\hline $\begin{array}{l}\text { Rochefort } \\
, 2010\end{array}$ & $\begin{array}{l}\text { All } \\
\text { nenonatial } \\
\text { ICUs in } \\
\text { Quebec }\end{array}$ & $339 \mathrm{RNs}$ & $\begin{array}{l}\text { Cross- } \\
\text { sectional } \\
\text { correlational } \\
\text { survey } \\
\text { design }\end{array}$ & $\begin{array}{l}\text { NWI-R, } \\
\text { Neonatal } \\
\text { Extent of } \\
\text { Work } \\
\text { Rationing } \\
\text { Inventory } \\
\text { (NEWRI), } \\
\text { MBI }\end{array}$ & $\begin{array}{l}\text { More favorable work } \\
\text { environments were related } \\
\text { to lower levels of nursing } \\
\text { care rationing. Specifically } \\
\text { rationing of parental } \\
\text { teaching, support, infant } \\
\text { comfort care, discharge } \\
\text { planning and care } \\
\text { coordination were } 11 \% \\
\text { lower when nurse staffing }\end{array}$ & $\begin{array}{l}\text { Self-reports of } \\
\text { some measures. } \\
\text { Newly } \\
\text { developed } \\
\text { instrument } \\
\text { NEWRI, cross- } \\
\text { sectional data } \\
\text { do not allow for } \\
\text { assessment of } \\
\text { causal }\end{array}$ \\
\hline
\end{tabular}




\begin{tabular}{|c|c|c|c|c|c|c|}
\hline & & & & & $\begin{array}{l}\text { and resource adequacy } \\
\text { were rated one point } \\
\text { higher. There was a 5.7\% } \\
\text { and } 7.7 \% \text { reduction in } \\
\text { rationing of life support, } \\
\text { technologically-oriented } \\
\text { nursing care, and patient } \\
\text { surveillance between the } \\
\text { best and worst ratings of } \\
\text { nurse staffing and resource } \\
\text { adequacy. } \\
\text { A } 4 \% \text { per unit increase in } \\
\text { nurse-physician } \\
\text { relationships was related to } \\
\text { a reduction rationing of life } \\
\text { support and } \\
\text { technologically-oriented } \\
\text { nursing care, and patient } \\
\text { surveillance. } \\
\text { Rationing of care was an } \\
\text { explanatory effect in the } \\
\text { relationship between } \\
\text { nurse-physician } \\
\text { relationships and } \\
\text { emotional exhaustion. }\end{array}$ & relationships. \\
\hline $\begin{array}{l}\text { Schubert, } \\
2008\end{array}$ & $\begin{array}{l}8 \text { Swiss } \\
\text { acute care } \\
\text { hospitals, } \\
118 \\
\text { medical, } \\
\text { surgical, } \\
\end{array}$ & $\begin{array}{l}1338 \\
\text { nurses, } 779 \\
\text { patients }\end{array}$ & $\begin{array}{l}\text { Multi- } \\
\text { hospital } \\
\text { cross- } \\
\text { sectional } \\
\text { survey }\end{array}$ & $\begin{array}{l}\text { Basel extent } \\
\text { of rationing of } \\
\text { nursing care } \\
\text { (BERNCA) }\end{array}$ & $\begin{array}{l}\text { Nurses reported low levels } \\
\text { of omitted care, but } \\
\text { implicit rationing of } \\
\text { nursing care was a } \\
\text { significant predictor of all } \\
\text { six patient outcomes }\end{array}$ & $\begin{array}{l}\text { Cross-sectional } \\
\text { design does not } \\
\text { imply causality } \\
\text { between } \\
\text { rationed nursing } \\
\text { care and patient }\end{array}$ \\
\hline
\end{tabular}




\begin{tabular}{|c|c|c|c|c|c|c|}
\hline & $\begin{array}{l}\text { and gyn } \\
\text { units }\end{array}$ & & & & $\begin{array}{l}\text { studied. The six patient } \\
\text { outcomes are: patient } \\
\text { satisfaction, medication } \\
\text { errors, patient falls, } \\
\text { nosocomial infections, } \\
\text { critical incidents, and } \\
\text { pressure ulcers. } \\
\text { Adequacy of nursing } \\
\text { resources was on a sig } \\
\text { predictor in adjusted } \\
\text { models. }\end{array}$ & $\begin{array}{l}\text { outcomes. } \\
\text { Conducted in } 1 \\
\text { country } \\
\text { accounting for } \\
\text { only } 10 \% \text { of } \\
\text { hospital beds. } \\
\text { Most variables } \\
\text { assessed } \\
\text { through nurse } \\
\text { reports. }\end{array}$ \\
\hline $\begin{array}{l}\text { Sochalski } \\
, 2004\end{array}$ & $\begin{array}{l}\text { Pennsylvan } \\
\text { ia }\end{array}$ & $\begin{array}{l}50 \% \\
\text { random } \\
\text { sample of } \\
\text { all RNs in } \\
\text { PA, } \mathrm{n}= \\
85,000 \\
\text { only } 9743 \\
\text { were used } \\
\text { after } \\
\text { exclusion/i } \\
\text { nclusion } \\
\text { criteria. }\end{array}$ & Survey & $\begin{array}{l}\text { Instruments } \\
\text { measuring: } \\
\text { quality of } \\
\text { nursing care, } \\
\text { patient } \\
\text { workload, } \\
\text { tasks undone, } \\
\text { patient safety } \\
\text { problems. }\end{array}$ & $\begin{array}{l}\text { Quality of nursing care sig } \\
\text { associated with number of } \\
\text { patients the nurse cares for, } \\
\text { rates of unfinished care for } \\
\text { the patients, and frequency } \\
\text { of patient safety problems. }\end{array}$ & \\
\hline
\end{tabular}


Appendix C

MISSCARE Survey 


\section{MISSED NURSING CARE (The MISSCARE Survey) Beatrice J. Kalisch}

1. Name of the unit you work on:

2. I spend the majority of my working time on this unit:

yes no

3. Highest education level:
1)
2)
3)
4)
5) Grade school High School Graduate (or GED)
Associate degree graduate
5) — Graduate degree

4. If you are a nurse, what is the highest degree:
1)
2)
3)
4)
5)
6)
7) LPN Diploma RN Diploma
Associate's degree in nursing (ADN)
Bachelor's degree in nursing (BSN)
_ Bachelor's degree outside of nursing
_ Master's degree (MSN) or higher in nursing
7) __ Master's degree or higher outside of nursing

5. Gender: Female Male

6. Age:
1) Under 25 years old $(<25)$
2) 25 to 34 years old (25-34)
3) 35 to 44 years old (35-44)
4) 45 to 54 years old $(45-54)$
5) 55 to 64 years old $(55-64)$
6) __ Over 65 years old $(65+)$

7. Job Title/Role:

1) Staff Nurse $(\mathrm{RN})$

2) Staff Nurse (LPN)

3) _ Nursing Assistant (e.g., nurse aides/tech)

4) _ Nurse manager, assistant manager (e.g. administrators on the unit)

5) _ Other [Please specify:

Please turn over to page 2 
8. Number of hours usually worked per week (check only one)

1) less than 30 hours per week

2) 30 hours or more per week

9. Work hours (check the one that is most descriptive of the hours you work)

1)

2) Days (8 or 12 hour shift)

3) Evenings (8 or12 hour shift)

4) Nights (8 or 12 hour shift) Rotates between days, nights or evenings

10. Experience in your role:

1) Up to 6 months

2) Greater than 6 months to 2 years

3) — Greater than 2 years to 5 years

4) __ Greater than 5 year to 10 years

5) __ Greater than 10 years

11. Experience on your current patient care unit:

1)

2) Gr_ater than 6 months to 2 years

3) Greater than 2 years to 5 years

4) G Greater than 5 year to 10 years

5) Greater than 10 years

12. Experience as a Registered Nurse:

1) U Up to 6 months

2) __ Greater than 6 months to 2 years

3) Greater than 2 years to 5 years

4) Greater than 5 year to 10 years

5) _ Greater than 10 years

13. Experience with current Electronic health record (EHR):

1) U Up to 6 months

2) Greater than 6 months to 2 years

3) G Greater than 2 years to 5 years

4) Greater than 5 year to 10 years

5) Greater than 10 years

14. Which shift do you most often work?

1)

2)

3)

4)

5) 8 hour shift 10 hour shift 12 hour shift 8 hour and 12 hour rotating shift

Other [Please specify: 
15. In the past 3 month, how many hours of overtime did you work?

1) None

2) 1-12 hours

3) More than 12 hours

16. In the past 3 months, how many days or shifts did you miss work due to illness, injury, extra rest etc. (exclusive of approved days off)?
1)
2) None
3) 2-3 days or shifts
4) _ 4-6 days or shifts
5) over 6 days or shifts

17. Do you plan to leave your current position?
1)
2) in the next 6 months
3) in the next year
3) no plans to leave

18. How often do you feel the unit staffing is adequate?
1)
2) $100 \%$ of the time
3) $50 \%$ of the time
4) $25 \%$ of the time
5) $0 \%$ of the time

19. On the current or last shift you worked, how many patients did you care for?

19-a. how many patient-admissions did you have (i.e. includes transfers into the unit)?

19-b. how many patient-discharges did you have (i.e. includes transfers out of the unit)?

Please turn over to page $4 \rightarrow$ 
Please check one response for each question.

\begin{tabular}{l|l|l|l|l|l}
\hline & $\begin{array}{c}\text { Very } \\
\text { satisfied }\end{array}$ & Satisfied & Neutral & Dissatisfied & $\begin{array}{c}\text { Very } \\
\text { dissatisfied }\end{array}$ \\
\hline $\begin{array}{l}\text { 20. How } \\
\text { satisfied are you } \\
\text { in your current } \\
\text { position? }\end{array}$ & & & & & \\
\hline $\begin{array}{l}21 . \text { Independent } \\
\text { of your current } \\
\text { job, how } \\
\text { satisfied are you } \\
\text { with being a } \\
\text { nurse or a } \\
\text { nurse } \\
\text { assistant? }\end{array}$ & & & & \\
\hline $\begin{array}{l}\text { 22. How } \\
\text { satisfied are you } \\
\text { with the level of } \\
\text { teamwork on } \\
\text { this unit? }\end{array}$ & & & & \\
\hline & & & & \\
\hline
\end{tabular}




\section{Section A - Missed Nursing Care}

Nurses frequently encounter multiple demands on their time, requiring them to reset priorities, and not accomplish all the care needed by their patients. To the best of your knowledge, how frequently are the following elements of nursing care MISSED by the nursing staff (including you) on your unit? Check only one box for each item.

\begin{tabular}{|l|l|l|l|l|l|}
\hline & $\begin{array}{c}\text { Always } \\
\text { missed }\end{array}$ & $\begin{array}{c}\text { Frequently } \\
\text { missed }\end{array}$ & $\begin{array}{c}\text { Occasionally } \\
\text { missed }\end{array}$ & $\begin{array}{l}\text { Rarely } \\
\text { missed }\end{array}$ & $\begin{array}{l}\text { Never } \\
\text { missed }\end{array}$ \\
\hline $\begin{array}{l}\text { 1) Ambulation three times per day } \\
\text { or as ordered }\end{array}$ & & & & & \\
\hline 2) Turning patient every 2 hours & & & & & \\
\hline $\begin{array}{l}\text { 3) Feeding patient when the food } \\
\text { is still warm }\end{array}$ & & & & & \\
\hline $\begin{array}{l}\text { 4) Setting up meals for patient } \\
\text { who feeds themselves }\end{array}$ & & & & & \\
\hline $\begin{array}{l}\text { 5) Medications administered } \\
\text { within 30 minutes before or after } \\
\text { scheduled time }\end{array}$ & & & & & \\
\hline 6) Vital signs assessed as ordered & & & & \\
\hline 7) Monitoring intake/output & & & & \\
\hline $\begin{array}{l}\text { 8) Full documentation of all } \\
\text { necessary data }\end{array}$ & & & & & \\
\hline $\begin{array}{l}\text { 9) Patient teaching about illness, } \\
\text { tests, and diagnostic studies }\end{array}$ & & & & & \\
\hline $\begin{array}{l}\text { 10) Emotional support to patient } \\
\text { and/or family }\end{array}$ & & & & & \\
\hline 11) Patient bathing/skin care & & & & & \\
\hline 12) Mouth care & & & & & \\
\hline 13) Hand washing & & & & \\
\hline $\begin{array}{l}\text { 14) Patient discharge planning and } \\
\text { teaching }\end{array}$ & & & & \\
\hline $\begin{array}{l}\text { 15) Bedside glucose monitoring } \\
\text { as ordered }\end{array}$ & & & & \\
\hline $\begin{array}{l}\text { 16) Patient assessments } \\
\text { performed each shift }\end{array}$ & & & & \\
\hline
\end{tabular}




\begin{tabular}{|l|l|l|l|l|l|}
\hline & $\begin{array}{c}\text { Always } \\
\text { missed }\end{array}$ & $\begin{array}{c}\text { Frequently } \\
\text { missed }\end{array}$ & $\begin{array}{c}\text { Occasionally } \\
\text { missed }\end{array}$ & $\begin{array}{l}\text { Rarely } \\
\text { missed }\end{array}$ & $\begin{array}{l}\text { Never } \\
\text { missed }\end{array}$ \\
\hline $\begin{array}{l}\text { 17) Focused reassessments } \\
\text { according to patient condition }\end{array}$ & & & & & \\
\hline $\begin{array}{l}\text { 18) IV/central line site care and } \\
\text { assessments according to } \\
\text { hospital policy }\end{array}$ & & & & & \\
\hline $\begin{array}{l}\text { 19) Response to call light is } \\
\text { initiated within 5 minutes }\end{array}$ & & & & & \\
\hline $\begin{array}{l}\text { 20) PRN medication requests } \\
\text { acted on within 15 minutes }\end{array}$ & & & & & \\
\hline $\begin{array}{l}\text { 21) Assess effectiveness of } \\
\text { medications }\end{array}$ & & & & & \\
\hline $\begin{array}{l}\text { 22) Attend interdisciplinary } \\
\text { care conferences whenever } \\
\text { held }\end{array}$ & & & & & \\
\hline $\begin{array}{l}\text { 23) Assist with toileting needs } \\
\text { within } 5 \text { minutes of request }\end{array}$ & & & & & \\
\hline 24) Skin/Wound care & & & & & \\
\hline
\end{tabular}

THANK YOU FOR YOUR PARTICIPATION! 


\section{Appendix D}

Impact of Healthcare Information Technology (I-HIT) Scale 
Impact of Healthcare Information Technology (I-HIT) Scale

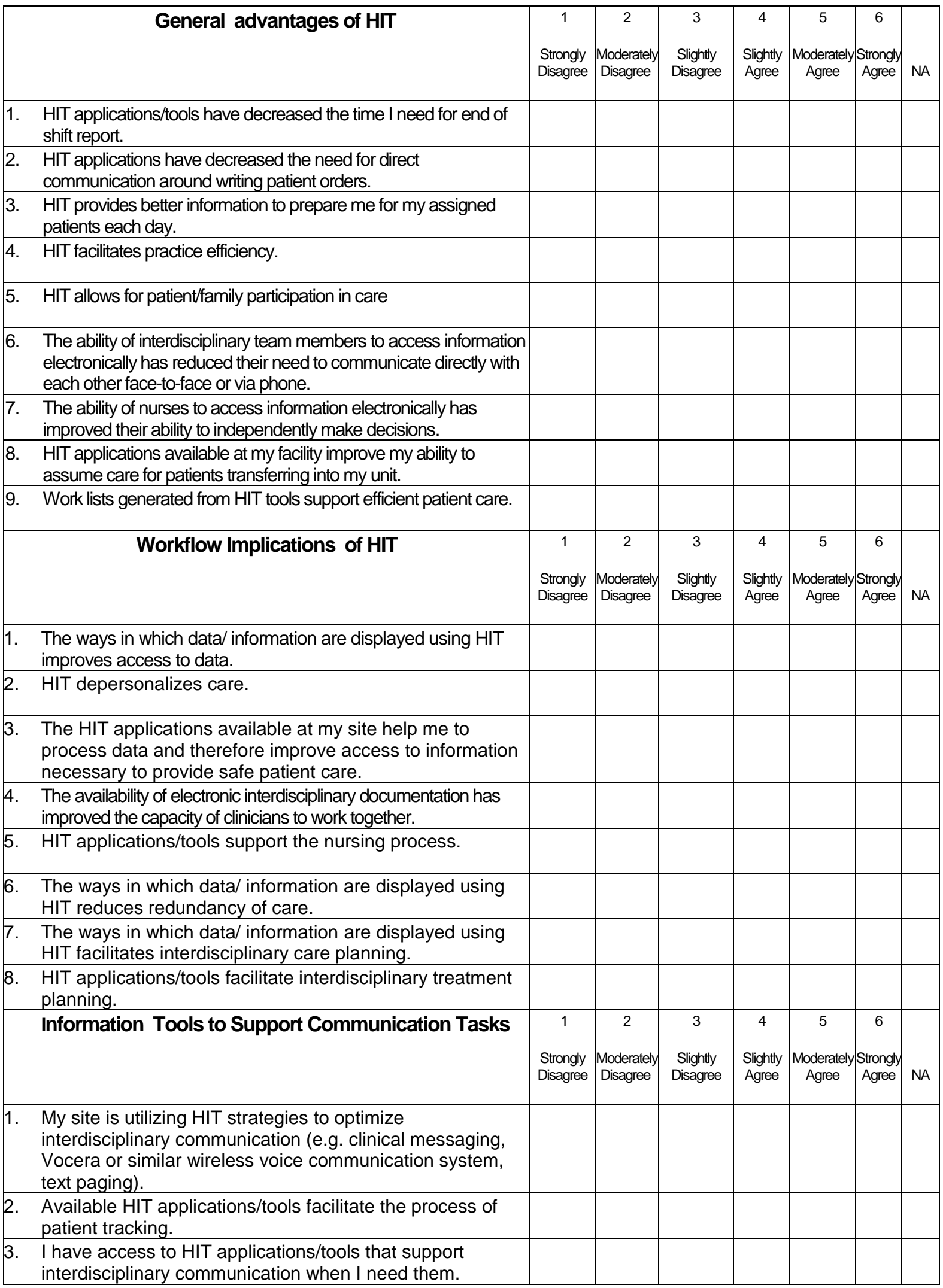


4. Available HIT tools support both patient care and administrative processes.

5. HIT facilitates ID communication that is patient centered.

6. The availability of information afforded by HIT at my site helps nurses collaborate at a higher level with interdisciplinary colleagues than was possible with paper systems.

7. I know how to access the HIT applications/tools available in the electronic medical record system.

Information Tools to Support Information Tasks

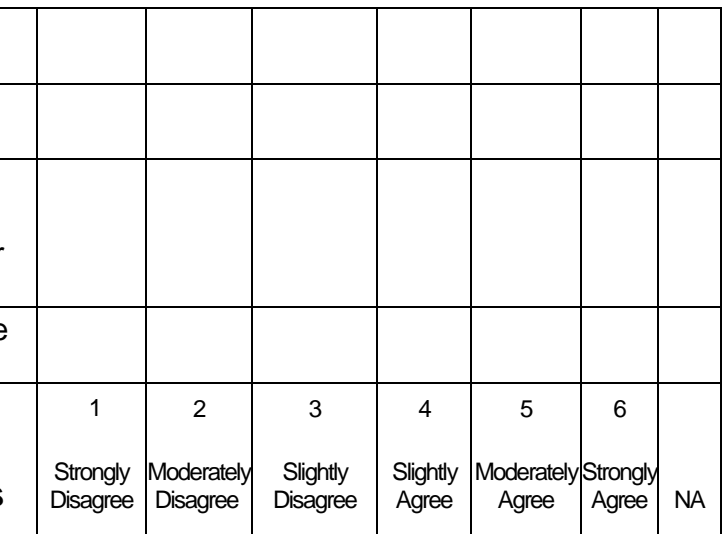

1. I find the acknowledgement features of current HIT applications/tools provide adequate assurance that my interdisciplinary colleagues have received the communications that I send

2. I find the acknowledgement features of current HIT applications/tools provide adequate assurance that interdisciplinary colleagues have acted upon information that I send.

3. HIT promotes 2-way communication between clinicians about patient status.

4. Communication of critical events to interdisciplinary colleagues can be done effectively using HIT.

5. HIT applications/tools help me to be problem-focused in my communications.

\begin{tabular}{lllllll|l|l|} 
& & & & & & & \\
\hline & & & & & & & \\
\hline s & & & & & & & \\
\hline
\end{tabular}

(C) Patricia C. Dykes and HIMSS Nursing Informatics, 2007.For questions about use please contact pdykes@partners.org 
Appendix E

Nursing Care Reminders Survey 


\section{Nursing Care Reminders Survey}

\section{Directions:}

1. Please rate each of the following statements regarding nursing reminders by clearly marking the choice that corresponds with your rating.

\section{Example:}

\begin{tabular}{|c|c|c|c|c|}
\hline Always & Frequently & Occasionally & Rarely & Never \\
\hline & $\mathrm{X}$ & & & \\
& & & & \\
\hline
\end{tabular}

2. Please be honest of your true ratings. This rating will not be shared with your peers and will not be used to determine your grade in the course.

\section{Definitions:}

a. EHR - An electronic database and accompanying graphical user interface which enables clinicians to document and retrieve patient care information that aids the clinician in clinical reasoning to make informed clinical decisions. This would include but is not limited to computerized physician order entry (CPOE), order and result processing and communication, patient scheduling, clinical reminders, task or work lists, and clinical documentation.

b. Nursing reminder - an electronic list, prompt, or cue of tasks or procedures that need to be completed by either the nurse or nursing attendant during their shift.

c. Nursing care activity - any patient care delivered by a nurse. 


\section{How frequently do you utilize the following types of nursing care reminders to assist you in completing}

nursing care activities?

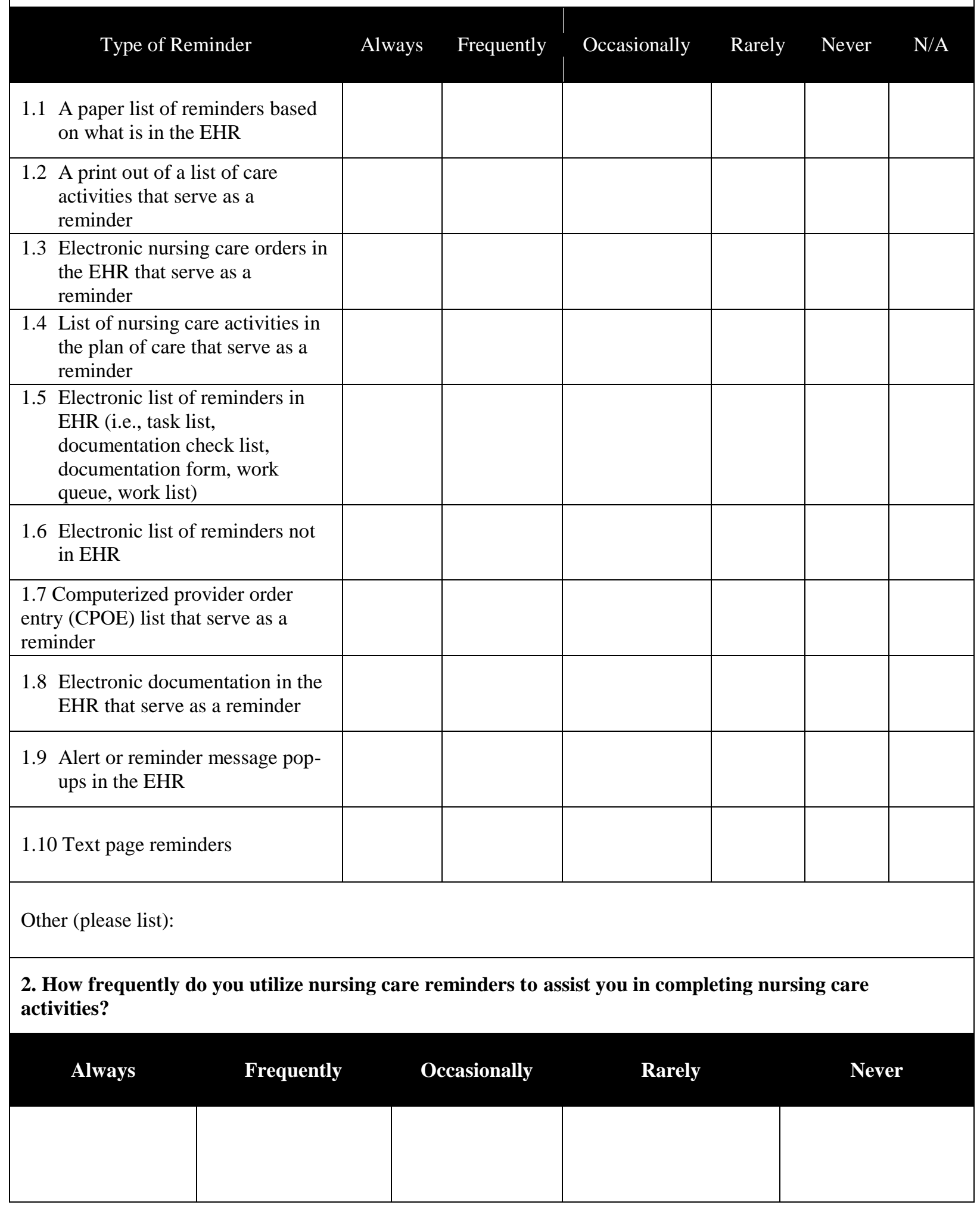


3. How helpful do you find the electronic nursing care reminders?

\begin{tabular}{|c|c|c|c|c|}
\hline Always & Frequently & Occasionally & Rarely & Never \\
\hline & & & & \\
\hline & & & & \\
\hline
\end{tabular}


Appendix F

Standardized Form to Collect Unit RNHPPD and CMI 
Standardized Form to Collect Unit RNHPPD and CMI

\begin{tabular}{|l|l|l|}
\hline \multicolumn{2}{|c|}{ Unit } & \\
\hline & & \\
\hline & & \\
\hline & & \\
\hline & & \\
\hline & & \\
\hline & & \\
\hline & & \\
\hline & & \\
\hline & & \\
\hline
\end{tabular}




\section{Appendix G}

Standardized Email Sent to Registered Nurses 


\section{Standardized Email Sent to Registered Nurses}

Dear Registered Nurse,

My name is Ronald Piscotty and I am a PhD in Nursing Student at the University of Michigan School of Nursing, Ann Arbor. I am currently conducting my dissertation research and would graciously appreciate your participation in my study.

The study is entitled: The Relationship Between Electronic Nursing Care Reminders and Missed Nursing Care. There are three short surveys that will need to be completed online using the web link listed below. The surveys should take no more than 20 minutes to complete and you can save your survey and return at a later time to complete. The surveys will ask about your perceptions of the impact of healthcare information technology on your practice and missed nursing care.

The survey will be open from to __. I will send periodic reminders each week to remind you to complete the survey. A unit incentive will be offered to the units that have $60 \%$ or higher of their nurses completing the survey. The incentive will be a Large Edible Arrangement delivered to each shift.

No identifying information will be collected; the data will kept anonymous and cannot be linked back to the person completing the survey.

By completing the survey you give your consent to participate in the study. If you do not wish to participate in this study, please do not complete the survey.

Should you have any questions about participating in the survey, please feel free to contact me at: piscotty@umich.edu or by phone at: 586-588-0271.

\section{Survey Link: PLEASE CLICK HERE TO BEGIN SURVEY}

Sincerely, Ronald Piscotty, MSN, RN-BC $\mathrm{PhD}$ in Nursing Candidate University of Michigan

School of Nursing piscotty@umich.edu 586-588-0271 


\section{Appendix $\mathrm{H}$}

Standardized Email Sent to Nursing Managers 


\section{Standardized Email Sent to Nursing Managers}

Dear (Nurse Manager),

My name is Ronald Piscotty and I am a PhD in Nursing Student at the University of Michigan School of Nursing, Ann Arbor. I am currently conducting my dissertation research and would graciously appreciate your units Registered Nurses participation in my study.

The study is entitled: The Relationship Between Electronic Nursing Care Reminders and Missed Nursing Care. There are three short surveys that will need to be completed online using an online web link. The surveys should take no more than 20 minutes to complete and can be saved and returned to a later time to complete. The surveys will ask about RN perceptions of the impact of healthcare information technology on their practice and missed nursing care.

The survey will be open from to I will send periodic reminders each week to remind the RNs to complete the survey. I would appreciate if you could remind your RN's to complete the survey each week as well. I will have flyers available to post on the unit as reminders as well. I would ask that you or the appropriate designee place the flyers in an area of high visibility by the RNs. A unit incentive will be offered to the units that have $60 \%$ or higher of their nurses complete the survey. The incentive will be a Large Edible Arrangement delivered to each shift.

No identifying information will be collected; the data will kept anonymous and cannot be linked back to the person completing the survey.

By completing the survey the RNs consent to participate in the study. If they do not wish to participate in this study, they do not need to complete the survey.

Should you have any questions about study or survey, please feel free to contact me at: piscotty@umich.edu or by phone at: 586-588-0271.

Sincerely, Ronald Piscotty, MSN, RN-BC

PhD in Nursing Candidate

University of Michigan

School of Nursing

piscotty@umich.edu

586-588-0271 
Appendix I

Standardized Flyer to Participate in Study 


\section{UNIVERSITY OF MICHIGAN}

\section{Is There a Relationship Between Electronic Nursing Care Reminders and Missed Nursing Care?}

My name is Ronald Piscotty and I am a PhD in Nursing Student at the University of Michigan School of Nursing, Ann Arbor. I am currently conducting my dissertation research and would graciously appreciate your participation in my study. An email with directions has been sent to your Beaumont email address.

The study is entitled: The Relationship Between Electronic Nursing Care Reminders and Missed Nursing Care. There are three short surveys that will need to be completed online using the web link listed below. The surveys should take no more than 20 minutes to complete and you can save your survey and return at a later time to complete. The surveys will ask about your perceptions of the impact of healthcare information technology on your practice and missed nursing care.

The survey will be open from to

A unit incentive will be offered to the units that have $60 \%$ or higher of their nurses completing the survey. The incentive will be a Large Edible Arrangement delivered to each shift.

No identifying information will be collected; the data will kept anonymous and cannot be linked back to the person completing the survey.

By completing the survey you give your consent to participate in the study. If you do not wish to participate in this study, please do not complete the survey.

Should you have any questions about participating in the survey, please feel free to contact me at: piscotty@umich.edu or by phone at: 586-588-0271.

Sincerely, Ronald Piscotty, MSN, RN-BC

$\mathrm{PhD}$ in Nursing Candidate

University of Michigan

School of Nursing piscotty@umich.edu 586-588-0271 


\section{BIBLIOGRAPHY}




\section{References}

Aarts, J., Ash, J., \& Berg, M. (2007). Extending the understanding of computerized physician order entry: Implications for professional collaboration, workflow and quality of care. International Journal of Medical Informatics, 76(1), S4-S13.

doi:10.1016/j.ijmedinf.2006.05.009

Agency of Healthcare Research and Quality (2011, April 11). AHRQ patient safety network: Glossary. Retrieved from http://psnet.ahrq.gov/glossary.aspx?indexLetter=E

Al-Kandari, F., \& Thomas, D. (2009). Factors contributing to nursing task incompletion as perceived by nurses working in Kuwait general hospitals. Journal of Clinical Nursing, 18(24), 3430-3440. doi: 10.1111/j.1365-2702.2009.02795.x

Alquraini, H., Alhashem, A., Shah, M., \& Chowdhury, R. (2007). Factors influencing nurses' attitudes towards the use of computerized health information systems in Kuwaiti hospitals. Journal of Advanced Nursing, 57(4), 375-381.

American Nurses Association. (2009). The National Database of Nursing Quality Indicators: Description and glossary. Silver Spring, MD: Author.

Ash, J. (2007). The extent and importance of unintended consequences related to computerized provider order entry. Journal of the American Medical Informatics Association, 14(4), 415423. doi:10.1197/jamia.M2373

Baron, R., \& Kenny, D. (1986). The moderator-mediator variable distinction in social psychological research: Conceputal, strategic, and statistical considerations. Journal of Personality and Social Psychology, 51(6), 1173-1182.

Barrett, E. (2002). What is nursing science?. Nursing Science Quarterly, 15(1), 51-60.

Bittner, N. P., \& Gravlin, G. (2009). Critical thinking, delegation, and missed care in nursing practice. The Journal of Nursing Administration, 39(3), 142-146. doi: 10.1097/NNA.0b013e31819894b7

Bittner, N. P., Gravlin, G., Hansten, R., \& Kalisch, B. J. (2011). Unraveling care omissions. The Journal of Nursing Administration, 41(12), 510-512. doi: 10.1097/NNA.0b013e3182378b65

Brink, P., \& Wood, M. (1998). Advanced design in nursing research (2nd ed.). Thousand Oaks, CA: Sage Publications, Inc.

Brixey, J., Robinson, D., Johnson, C., Johnson, T., Turely, J., \& Zhang. (2007). A concept analysis of the phenomenon interruption. Advances in Nursing Science, 30(1), E26-E42. 
Campion, T., Waitman, L., Lorenzi, N., May, A., \& Gadd, C. (2011). Barriers and facilitators to the use of computer-based intensive insulin therapy. International Journal of Medical Informatics, 80(12), 863-871. doi: 10.1016/j.ijmedinf.2011.10.003

Cho, I., Staggers, N., \& Park, I. (2010). Nurses' responses to differing amounts and information content in a diagnostic computer-based decision support application. Computers, Informatics, Nursing, 28(2), 95-102. doi: 10.1097/NCN.0b013e3181cd8240

Choi, M., Choi, R., Bae, Y., \& Lee, S. (2011). Clinical decision support systems for patient safety: A focus group needs assessment with Korean ICU nurses. Computers, Informatics, Nursing, 29(11), 671-678. doi: 10.1097/NCN.0b013e3182148c18

Courtney, K., Alexander, G., \& Demiris, G. (2008). Information technology from novice to expert: Implementation implications. Journal of Nursing Management, 16(6), 692-9.

Currie, L. (2008). Patient safety and health information technology: Role of the electronic health record. In Hughes, R. G. (Ed.). Patient safety and quality: An evidenced-based handbook for nurses (pp. 1234-1276) (AHRQ Publication No. 08-0043). Rockville, MD: Agency for Healthcare Research and Quality.

Davis, F. (1989). Perceived usefulness, perceived ease of use, and user acceptance of information technology. MIS Quarterly, 13(3), 319-340.

Davis, F., Bagozzi, R., \&Warshaw, P. (1989). User acceptance of computer technology: A comparison of two theoretical models. Management Science, 35(8), 982-1003.

Donabedian, A. (1966). Evaluating the quality of medical care. The Milbank Memorial Fund Quarterly, 44(3), 166-206.

Donabedian, A. (1969). Part II: Some issues in evaluating the quality of nursing care. American Journal of Public Health and the Nation's Health, 59(10), 1833-1836.

Donabedian, A. (1988). The quality of care. how can it be assessed? The Journal of the American Medical Association, 260(12), 1743-1748. doi: 10.1001/jama.1988.03410120089033

Dowding, D., Randell, R., Mitchell, N., Foster, R., Thomopson, C., Lattimer, V., \& Cullum, N. (2009a). Experience and nurses use of computerised decision support systems. Studies in Health Technology and Informatics, 146, 506-510.

Dowding, D., Mitchell, N., Randell, R., Foster, R., Lattimer, V., \& Thomopson, C. (2009b). Nurses' use of computerised clinical decision support systems: a case site analysis. Journal of Clinical Nursing, 18, 1159-1167.

Dykes, P. C., Hurley, A., Cashen, M., Bakken, S., Duffy, M. E. (2007). Development and psychometric evaluation of the Impact of Health Technology (I-HIT) Scale. Journal of the American Medical Informatics Association, 14(4), 507-514. 
Effken, J. (2003). An organizing framework for nursing informatics research. Computers, Informatics, Nursing, 21(6), 316-323.

Ernesater, A., Holmstram, I., \& Engstram, M. (2009). Telenurses' experiences of working with computerized decision support: Supporting, inhibiting and quality improving. Journal of Advanced Nursing, 65(5), 1074-1083.

Garg, A., Adhikari, N., McDonald, H., Rosas-Arellano, M., Devereaux, P., Beyene, J., Sam, J., \& Haynes, R. (2005). Effects of computerized clinical decision support systems on practitioner performance and patient outcomes: A systematic review. Journal of the American Medical Association, 293(10), 1223-1238.

Goldzweig, C. L., Towfigh, A., Maglione, M., and Shekelle, P. G. (2009). Costs and benefits of health information technology: New trends from the literature. Health Affairs, 28(2), w282w293. doi: 10.1377/hlthaff.28.2.w282

Gravlin, G., \& Bittner, N. (2010). Nurses' and nursing assistants' reports of missed care and delegation. The Journal of Nursing Administration, 40(7-8), 329-335. doi:

10.1097/NNA.0b013e3181e9395e

Han, Y., Carcillo, J., Venkataraman, S., Clark, R., Watson, R., Nguyen, T., ... Orr, R. (2005). Unexpected increased mortality after implementation of a commercially sold computerized physician order entry system. Pediatrics, 116(6), 1506-1512. doi:10.1542/peds.2005-1287

Harrison, M., Koppel, R., \& Bar-Lev, S. (2007). Unintended consequences of information technologies in health care: An interactive sociotechnical analysis. Journal of the American Medical Informatics Association, 14(5), 542-549. doi:10.1197/jamia.M2384

Healthcare Information and Management Systems Society (2010, December 3). HIMSS health information exchange: ARRA, HITECH FAQs related to HIE. Retrieved from: http://www.himss.org/content/files/12_04_09_ARRAHITECHHIE_FactSheet.pdf

Hunt, D., Haynes, R., Hanna, S., \& Smith, K. (1998). Effects of computer-based clinical decision support systems on physician performance and patient outcomes: A systematic review. Journal of the American Medical Association, 280(15), 1339-1346.

Institute of Medicine of the National Academies. (1999). To err is human: Building a safer health system. Washington, DC: National Academy Press.

Institute of Medicine of the National Academies. (2001). Crossing the quality chasm: A new health system for the 21st Century. Washington, DC: National Academy Press.

Institute of Medicine of the National Academies. (2003). Keeping patients safe: Transforming the work environment of nurses. Washington, DC: National Academy Press.

Institute of Medicine of the National Academies (2009, November 1). Interactive list of comparative effectiveness research (CER) areas. Retrieved from 
http://www.iom.edu/en/Reports/2009/ComparativeEffectivenessResearchPriorities.aspx.

Kalisch, B. J. (2006). Missed nursing care: a qualitative study. Journal of Nursing Care Quality, 21(4), 306-313.

Kalisch, B. J., \& Williams, R. A. (2009). Development and psychometric testing of a tool to measure missed nursing care. The Journal of Nursing Administration, 39(5), 211-219. doi: 10.1097/NNA.0b013e3181a23cf5

Kalisch, B. J., Landstrom, G. L., \& Hinshaw, A. S. (2009). Missed nursing care: a concept analysis. Journal of Advanced Nursing, 65(7), 1509-1517. doi: 10.1111/j.13652648.2009.05027.x

Kalisch, B. J., Landstrom, G., \& Williams, R. A. (2009). Missed nursing care: errors of omission. Nursing Outlook, 57(1), 3-9. doi: 10.1016/j.outlook.2008.05.007

Kalisch, B. J. (2009). Nurse and nurse assistant perceptions of missed nursing care: what does it tell us about teamwork? The Journal of Nursing Administration, 39(11), 485-493. doi: 10.1097/NNA.0b013e3181bd61ac

Kalisch, B. J. \&, Aebersold, M. (2010). Interruptions and multitasking in nursing care. Joint Commission Journal of Quality and Patient Safety, 36(3), 126-132.

Kalisch, B. J., \& Lee, K. H. (2010). The impact of teamwork on missed nursing care. Nursing outlook, 58(5), 233-241. doi: 10.1016/j.outlook.2010.06.004

Kalisch, B. J., Tschannen, D., \& Lee, K. H. (2011). Do staffing levels predict missed nursing care? International Journal for Quality in Health Care, 23(3), 302-308. doi: 10.1093/intqhe/mzr009

Kalisch, B., Tschannen, D., Lee, H., \& Salsgiver, M. (2011). Does missed nursing care predict job satisfaction? Journal of Healthcare Management, 56(2), 117-131.

Kalisch, B. J., Tschannen, D., Lee, H., \& Friese, C. R. (2011). Hospital variation in missed nursing care. American Journal of Medical Quality, 26(4), 291-299. doi: $10.1177 / 1062860610395929$

Kalisch, B. J., Gosselin, K., \& Choi, S. H. (2012). A comparison of patient care units with high versus low levels of missed nursing care. Health Care Management Review. doi: 10.1097/HMR.0b013e318249727e

Kalisch, B. J., Tschannen, D., \& Lee, K. H. (2012). Missed nursing care, staffing, and patient falls. Journal of Nursing Care Quality, 27(1), 6-12. doi: 10.1097/NCQ.0b013e318225aa23

Kalisch, B. J., McLaughlin, M., \& Waller-Dabney. (2012). Patient perceptions of missed nursing care. The Joint Commission Journal on Quality and Patient Safety, 38(4), 161-167. 
Kawamoto, K., Houlihan, C., Balas, E., \& Lobach, D. (2005). Improving clinical practice using clinical decision support systems: A systematic review of trials to identify features critical to success. BMJ (Clinical Research Ed), 330(7494), 765.

Koppel, R., Metlay, J. P., Cohen, A., Abaluck, B., Localio, J. D., Kimmel, S. E., \& Strom, B. L. (2005). Role of computerized physician order entry systems in facilitating medication errors. Journal of the American Medical Association, 293(10), 1197-1203. doi: 10.1001/jama.293.10.1197

Lawless, J., Wan, L., \& Zeng, I. (2010). Patient care 'rationed' as nurses struggle under heavy workloads--survey. Nursing New Zealand, 16(7), 16-18.

Marshall, A., West, S., \& Aitken, L. (2011). Preferred information sources for clinical decision making: Critical care nurses' perceptions of information accessibility and usefulness. Worldviews on Evidence-Based Nursing, 8(4), 224-235. doi: 10.1111/j.17416787.2011.00221.x

Mitchell, P., Ferketich, S., \& Jennings, B. (1998). Quality Health Outcome Model. Image: Journal of Nursing Scholarship, 30(1), 43-46.

O'Cathain, A., Munro, J., Armstrong, I., O'Donnell, C., \& Heaney, D. (2007). The effect of attitude to risk on decisions made by nurses using computerised decision support software in telephone clinical assessment: An observational study. BMC Medical Informatics and Decision Making, 7, 39.

O'Neill, E., Dluhy, N., Hansen, A., \& Ryan, J. (2006). Coupling the N-CODES system with actual nurse decision-making. Computers, Informatics, Nursing, 24(1), 28-26.

Pape. (2002). The effect of nurses' use of a focused protocol to reduce distractions during medication administration. (Unpublished Doctoral dissertation). Texas Woman's University, Houston, TX.

Pape, T., Guerra, D., Muzquiz, M., Bryant, J., Ingram, M, Schranner, B., ... Welker, J. (2005). Innovative approaches to reducing nurses' distractions during medication administration. Journal of Continuing Education in Nursing, 36(3), 108-116.

Piscotty, R., \& Tzeng, H. (2011). Exploring the clinical information system implementation readiness activities to support nursing in hospital settings. Computers, Informatics, Nursing, 29(11), 648-565. doi: 10.1097/NCN.0b013e31821a153f

Polit, D. (2010). Statistics and data analysis for nursing research (2nd ed.). Uppersaddle River, NJ: Pearson Education Inc.

Powell-Cope, A., Nelson, A., \& Patterson, E. (2008). Patient safety and health information technology: Role of the electronic health record. In Hughes, R. G. (Ed.). Patient safety and 
quality: An evidenced-based handbook for nurses (pp. 1234-1276) (AHRQ Publication No. 08-0043). Rockville, MD: Agency for Healthcare Research and Quality.

Randell, R., \& Dowding, D. (2010). Organisational influences on nurses' use of clinical decision support systems. International Journal of Medical Informatics, 79(6), 412-421. doi: 10.1016/j.ijmedinf.2010.02.003

Randell, R., Mitchell, N., Thompson, C., McCaughan, D., \& Dowding, D. (2009). Supporting nurse decision making in primary care: Exploring use of and attitude to decision tools. Health Informatics Journal, 15(1), 5-16.

Randell, R., Mitchell, N., Dowding, D., Cullum, N., and Thompson, C. (2007). Effects of computerized decision support systems on nursing performance and patient outcomes: A systematic review. Journal of Health Services Research and Policy, 12(4), 242-249.

Rochefort, C. M., \& Clarke, S. P. (2010). Nurses' work environments, care rationing, job outcomes, and quality of care on neonatal units. Journal of Advanced Nursing, 66(10), 2213-2224. doi: 10.1111/j.1365-2648.2010.05376.x

Rawnsley, M. (2003). Dimensions of scholarship and the advancement of nursing science: Articulating a vision. Nursing Science Quarterly, 16(1), 6-15.

Saleem, J., Patterson, E., Militello, L., Anders, S., Falciglia, M., Wissman, J., Roth, E., \& Asch, S. (2007). Impact of clinical reminder redesign on learnability, efficiency, usability, and workload for ambulatory clinic nurses. Journal of the American Medical Informatics Association, 14(5), 632-640.

Saleem, J., Patterson, E., Militello, L., Render, M., Orshansky, G., \& Asch, S. (2005). Exploring barriers and facilitators to the use of computerized clinical reminders. Journal of the American Medical Informatics Association, 12(4), 438-447.

Schubert, M., Glass, T. R., Clarke, S. P., Aiken, L. H., Schaffert-Witvliet, B., Sloane, D. M., \& De Geest, S. (2008). Rationing of nursing care and its relationship to patient outcomes: the Swiss extension of the International Hospital Outcomes Study. International Journal for Quality in Health, 20(4), 227-237. doi: 10.1093/intqhe/mzn017

Sochalski, J. (2004). Is more better?: the relationship between nurse staffing and the quality of nursing care in hospitals. Medical Care, 42(2 Suppl), II67-73. doi: 10.1097/01.mlr.0000109127.76128.aa

Staggers, N., Weir, C., and Phansalkar, S. (2008). Patient safety and health information technology: Role of the electronic health record. In Hughes, R. G. (Ed.). Patient safety and quality: An evidenced-based handbook for nurses (pp. 1234-1276) (AHRQ Publication No. 08-0043). Rockville, MD: Agency for Healthcare Research and Quality. 
Tabachnik, \& Fidell, (2007). Using multivariate statistics (5th ed.). Boston, MA: Pearson Education, Inc.

Titler, M. (2008). Patient safety and health information technology: Role of the electronic health record. In Hughes, R. G. (Ed.). Patient safety and quality: An evidenced-based handbook for nurses (pp. 1234-1276) (AHRQ Publication No. 08-0043). Rockville, MD: Agency for Healthcare Research and Quality.

Tschannen, D., Kalisch, B. J., \& Lee, K. H. (2010). Missed nursing care: the impact on intention to leave and turnover. The Canadian Journal of Nursing, 42(4), 22-39.

U.S. Department of Health and Human Services (2009, November 1). Proposed HP2020 objectives: Health communication and health IT. Retrieved from http://www.healthypeople.gov/HP2020/Objectives/TopicArea.aspx?id=25\&TopicArea=Hea lth+Communication+and+Health+IT

Walker, L., \& Avant, K. (2005). Strategies for theory construction in nursing. Uppers Saddle River, NJ: Pearson Prentice Hall.

Weber, S., Courtney, K., \& Benham-Hutchins, M. (2009). Decision support in multi-professional communication. Journal of Medical Systems, 33(1), 59-65.

Weir, C., Nebeker, J., Hicken, B., Campo, R., Drews, F., \& Lebar, B. (2007). A cognitive task analysis of information management strategies in a computerized provider order entry environment. Journal of the American Medical Informatics Association: JAMIA, 14(1), $65-$ 75. 